Prepared in cooperation with Upper Yampa River Watershed Group, Upper Yampa Water Conservancy District, Colorado Water Conservation Board, Yampa-White-Green Basin Roundtable, Mount Werner Water and Sanitation District, Routt County, Colorado, and the city of Steamboat Springs, Colorado

\title{
Assessment of Streamflow and Water Quality in the Upper Yampa River Basin, Colorado, 1992-2018
}

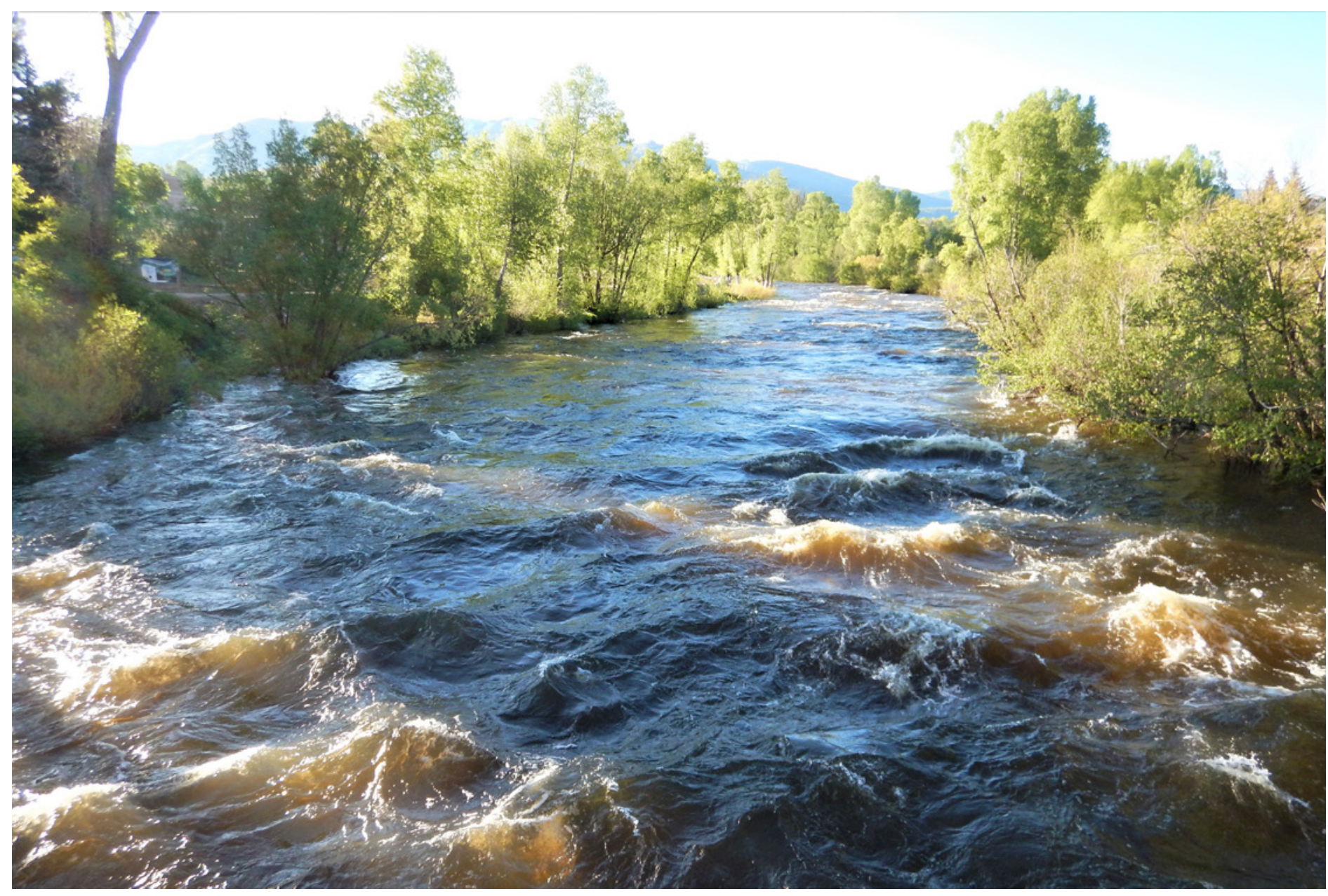

Scientific Investigations Report 2021-5016 
Cover. Photograph of the Yampa River taken at the site of the U.S. Geological Survey streamgage Yampa River at Steamboat Springs, Colo. (site number 09239500) [Photograph by Jeff Foster, U.S. Geological Survey, 2019]. 


\section{Assessment of Streamflow and Water Quality in the Upper Yampa River Basin, Colorado, 1992-2018}

By Natalie K. Day

Prepared in cooperation with Upper Yampa River Watershed Group, Upper Yampa Water Conservancy District, Colorado Water Conservation Board, Yampa-White-Green Basin Roundtable, Mount Werner Water and Sanitation District, Routt County, Colorado, and the city of Steamboat Springs, Colorado

Scientific Investigations Report 2021-5016 


\section{U.S. Geological Survey, Reston, Virginia: 2021}

For more information on the USGS - the Federal source for science about the Earth, its natural and living resources, natural hazards, and the environment—visit https://www.usgs.gov or call 1-888-ASK-USGS.

For an overview of USGS information products, including maps, imagery, and publications, visit https://store.usgs.gov/.

Any use of trade, firm, or product names is for descriptive purposes only and does not imply endorsement by the U.S. Government.

Although this information product, for the most part, is in the public domain, it also may contain copyrighted materials as noted in the text. Permission to reproduce copyrighted items must be secured from the copyright owner.

Suggested citation:

Day, N.K., 2021, Assessment of streamflow and water quality in the Upper Yampa River Basin, Colorado, 1992-2018:

U.S. Geological Survey Scientific Investigations Report 2021-5016, 45 p., https://doi.org/10.3133/sir20215016.

Data associated with this publication:

Day, N.K., 2021, Input and output data from streamflow and water-quality regression models used to characterize streamflow and water-quality conditions in the Upper Yampa River Basin, Colorado, from 1992 to 2018: U.S.

Geological Survey data release, https://doi.org/10.5066/P9L7S3NQ.

ISSN 2328-031X (print)

ISSN 2328-0328 (online)

ISBN 978-1-4113-4402-0 


\section{Contents}

Abstract

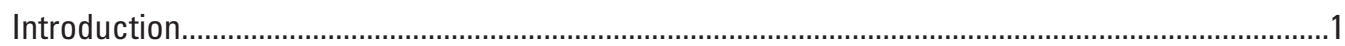

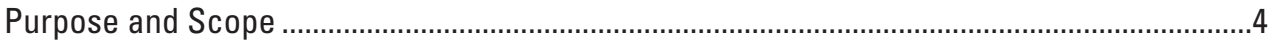

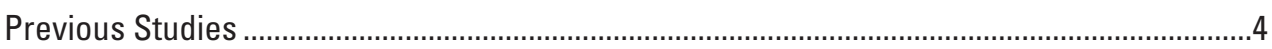

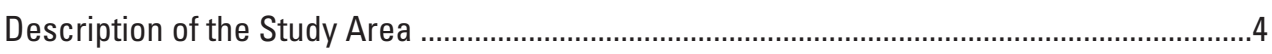

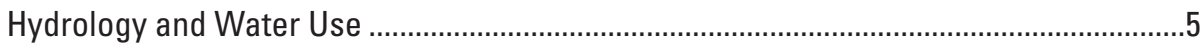

Approach and Methods .........................................................................................................

Data Compilation and Quality Assurance ……………….........................................................

Extension of Streamflow Record.....................................................................................

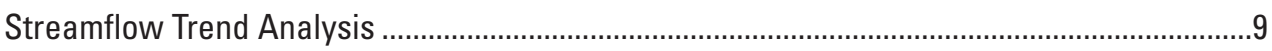

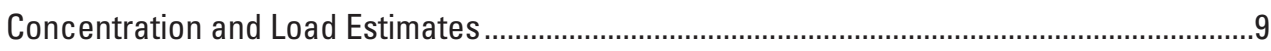

Comparison to Interim Concentrations for Water-Quality Standards ......................................10

Normalized Mean Daily Streamflows, Loads, and Yields........................................................10

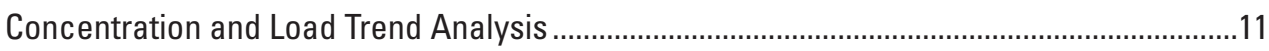

Multiple Linear Regression Trend Analysis...................................................................11

Weighted Regression Trend Analysis ............................................................................11

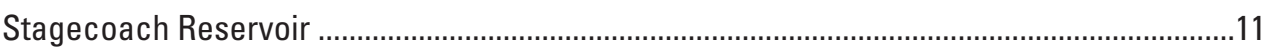

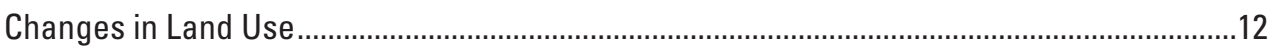

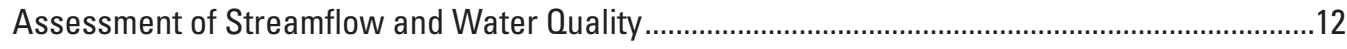

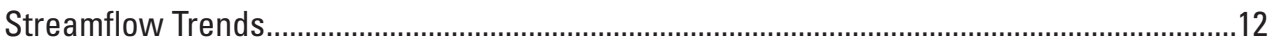

Concentration Estimates and Comparisons to Interim Concentrations for

Water-Quality Standards........................................................................................16

Regression Equation Variable Coefficients and Statistical Diagnostics ................................16

Suspended Sediment ................................................................................................

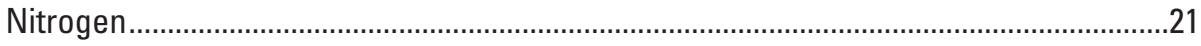

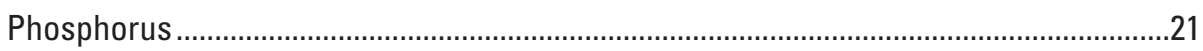

Load Estimation and Streamflow-Normalized Load and Yield Analysis .................................26

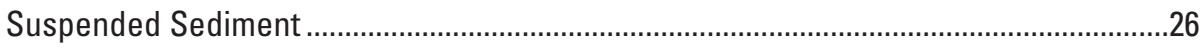

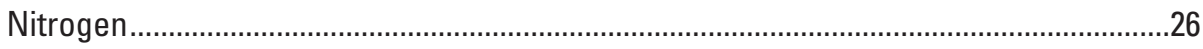

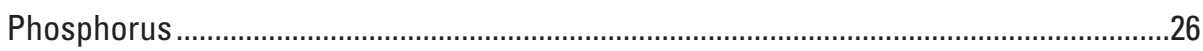

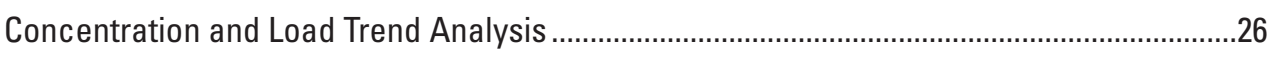

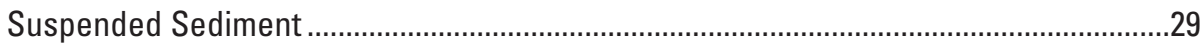

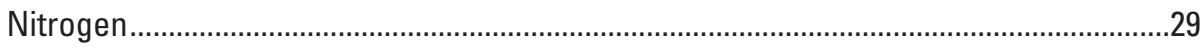

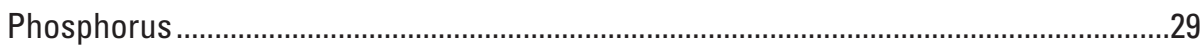

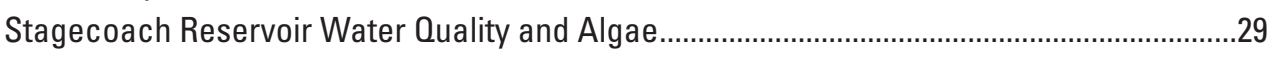

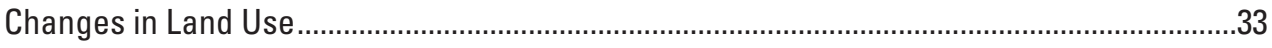

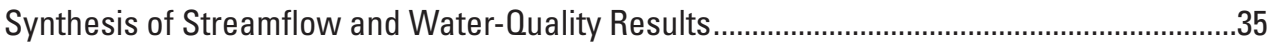

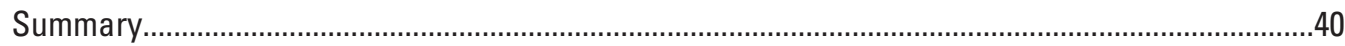

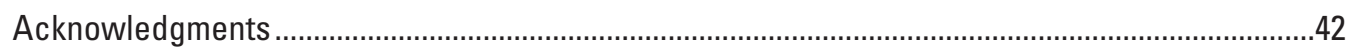

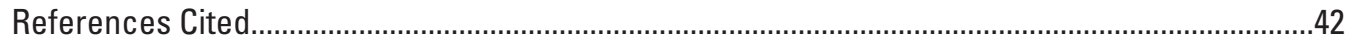




\section{Figures}

1. Map showing the location of the Upper Yampa River Basin, Colorado, with selected U.S. Geological Survey water-quality sites and water year 2018 streamgage sites

2. Map showing Cretaceous-aged sandstones, shales, and major coal beds of the Upper Yampa River Basin, Colorado..

3. Graph showing the mean monthly streamflow at selected streamgage sites in the Upper Yampa River Basin, Colorado, for water years 2013 through 2018.

4. Graphs showing changes in 1-day maximum, mean, and 7-day minimum streamflow statistics at five main-stem Yampa River sites in the Upper Yampa River Basin from climate years 1992 to 2018.

5. Graphs showing changes in 1-day maximum, mean, and 7-day minimum streamflow statistics for various time periods at 3 tributary sites in the Upper Yampa River Basin and 1 Yampa River main-stem site

6. Graph showing the temporal deviation from the mean peak streamflow date at Yampa River at Steamboat Springs, Colo., for water years 1910-2018.

7. Discrete concentrations and boxplots of model-estimated daily mean concentrations of suspended sediment at five sites in the Upper Yampa River Basin, Colorado, on a monthly basis for water years 2010-18.

8. Discrete concentrations and boxplots of model-estimated daily mean concentrations of Kjeldahl nitrogen at eight sites in the Upper Yampa River Basin, Colorado, for various starting water years through water year 2018

9. Discrete concentrations of total nitrogen at eight sites in the Upper Yampa River Basin, Colorado, for various starting water years through water year 2018.........22

10. Graphs showing discrete concentrations of total phosphorus and suspended sediment at five sites in the Upper Yampa River Basin, Colorado, for water years 2010-18

11. Discrete concentrations and boxplots of model-estimated daily mean concentrations of total phosphorus at eight sites in the Upper Yampa River Basin, Colorado, for various starting water years through 2018

12. Graphs of discrete concentrations of orthophosphate at eight sites in the Upper Yampa River Basin, Colorado, for various starting water years through 2018

13. Graphs showing annual loads and net yields of suspended sediment, Kjeldahl nitrogen, and total phosphorus, based on normalized hydrographs at select sites in the Upper Yampa River Basin, Colorado, for water years 2010-18

14. Graphs showing estimated annual concentrations and loads and streamflow-normalized trends for Kjeldahl nitrogen and total phosphorus using weighted regression trend analysis at Yampa River at Steamboat Springs, Colorado (CO), and Yampa River at Craig, CO, in the Upper Yampa River Basin for water years 1999-2018.

15. Graphs showing water temperature, dissolved oxygen concentration, total phosphorus concentration, total nitrogen concentration, ratio of total nitrogen to total phosphorus, and chlorophyll a concentrations at two depths at Stagecoach Reservoir at Dam, Colorado, in July-September 2017 and 2018.

16. Graph showing planktonic algal cell densities, in cells per milliliter, in Stagecoach Reservoir at Dam, Colorado, in July-September 2017 and 2018. .35

17. Map showing land cover in the Upper Yampa River Basin, Colorado, in 2016 .................36

18. Graph showing percentage of land-use cover classes in the Upper Yampa River Basin, Colorado, and its subbasins in 2016. 


\section{Tables}

1. Summary of U.S. Geological Survey water-quality and streamgage sites in the Upper Yampa River Basin, Colorado, included in this report...

2. Colorado Department of Public Health and Environment interim concentrations for total nitrogen, total phosphorus, and chlorophyll a water-quality standards for surface water in the Upper Yampa River Basin, Colorado

3. Regression model coefficients and statistical diagnostics for concentrations of suspended sediment at 5 sites, and Kjeldahl nitrogen and total phosphorus at 7 sites in the Upper Yampa River Basin, Colorado

4. Regression model coefficients and statistical diagnostics for loads of suspended sediment at 5 sites, and Kjeldahl nitrogen and total phosphorus at 7 sites, in the Upper Yampa River Basin, Colorado

5. Estimated annual median and median annual concentrations of suspended sediment at 5 water-quality sites in the Upper Yampa River Basin, Colorado, and Kjeldahl nitrogen and total phosphorus at 7 water-quality sites in the Upper Yampa River Basin for water years 2010-18

6. Estimated monthly and annual loads and annual yields, based on normalized hydrographs, of suspended sediment for 5 sites, and Kjeldahl nitrogen and total phosphorus for 7 sites listed in downstream order in the Upper Yampa River Basin, Colorado, for water years 2010-18, and changes in annual loads at Yampa River sites.

7. Results of weighted-regression trend analysis and regression statistics for annual streamflow-normalized concentrations and loads at Yampa River at Steamboat Springs, Colorado, and Yampa River below Craig, CO for water years 1999-2018

8. Change in forest and development land-cover classes in the Upper Yampa

River Basin, Colorado, and subbasins from 2001 to 2016 


\section{Conversion Factors}

U.S. customary units to International System of Units

\begin{tabular}{|c|c|c|}
\hline Multiply & By & To obtain \\
\hline \multicolumn{3}{|c|}{ Length } \\
\hline foot $(\mathrm{ft})$ & 0.3048 & meter (m) \\
\hline \multicolumn{3}{|c|}{ Area } \\
\hline square mile $\left(\mathrm{mi}^{2}\right)$ & 2.590 & square kilometer $\left(\mathrm{km}^{2}\right)$ \\
\hline \multicolumn{3}{|c|}{ Volume } \\
\hline gallon (gal) & 3.785 & liter $(\mathrm{L})$ \\
\hline acre-foot (acre-ft) & 1,233 & cubic meter $\left(\mathrm{m}^{3}\right)$ \\
\hline \multicolumn{3}{|c|}{ Flow rate } \\
\hline cubic foot per second $\left(\mathrm{ft}^{3} / \mathrm{s}\right)$ & 0.02832 & cubic meter per second $\left(\mathrm{m}^{3} / \mathrm{s}\right)$ \\
\hline inch per year (in/yr) & 25.4 & millimeter per year $(\mathrm{mm} / \mathrm{yr})$ \\
\hline \multicolumn{3}{|c|}{ Mass } \\
\hline ton, short $(2,000 \mathrm{lb})$ & 0.9072 & metric ton $(\mathrm{t})$ \\
\hline
\end{tabular}

International System of Units to U.S. customary units

\begin{tabular}{lcl}
\hline & Multiply & To obtain \\
\hline \multicolumn{3}{c}{ Length } \\
\hline micron & 0.001 & millimeter \\
\hline \multicolumn{3}{c}{ Area } \\
\hline square meter $\left(\mathrm{m}^{2}\right)$ & 0.0002471 & acre \\
\hline \multicolumn{3}{c}{ Volume } \\
\hline liter $(\mathrm{L})$ & 33.81402 & ounce, fluid (fl. oz) \\
\hline
\end{tabular}

Temperature in degrees Celsius $\left({ }^{\circ} \mathrm{C}\right)$ may be converted to degrees Fahrenheit $\left({ }^{\circ} \mathrm{F}\right)$ as follows:

$$
{ }^{\circ} \mathrm{F}=\left(1.8 \times{ }^{\circ} \mathrm{C}\right)+32 .
$$

Temperature in degrees Fahrenheit $\left({ }^{\circ} \mathrm{F}\right)$ may be converted to degrees Celsius $\left({ }^{\circ} \mathrm{C}\right)$ as follows:

$$
{ }^{\circ} \mathrm{C}=\left({ }^{\circ} \mathrm{F}-32\right) / 1.8 \text {. }
$$

\section{Datum}

Vertical coordinate information is referenced to the North American Vertical Datum of 1988.

Horizontal coordinate information is referenced to the Geographic Coordinate System North America coordinate system of 1983.

Elevation, as used in this report, refers to distance above the vertical datum. 


\section{Supplemental Information}

Concentrations of chemical constituents in water are given in milligrams per liter ( $\mathrm{mg} / \mathrm{L}$ ) or micrograms per liter $(\mu \mathrm{g} / \mathrm{L})$.

Streamflow is given in cubic feet per second $\left(\mathrm{ft}^{3} / \mathrm{s}\right)$.

"Water year" is the 12-month period from 0ctober 1 through September 30. The water year is designated by the year in which it ends.

"Climate year" is the 12-month period beginning April 1 and ending March 31 of the following year. The climate year is designated as the year in which it begins.

\section{Abbreviations}

$\begin{array}{ll}> & \text { greater than } \\ < & \text { less than } \\ \text { CDPHE } & \text { Colorado Department of Public Health and Environment } \\ \text { CO } & \text { Colorado, in USGS site names } \\ \text { CY } & \text { climate year } \\ \text { CyanoHABs } & \text { cyanobacterial harmful algal blooms } \\ \text { MOVE.2 } & \text { Maintenance of Variance Extension Type 2 } \\ \text { NWIS } & \text { National Water Information System } \\ \text { R }^{2} & \text { coefficient of determination } \\ \text { TN:TP } & \text { total nitrogen to total phosphorus ratio } \\ \text { USGS } & \text { U.S. Geological Survey } \\ \text { UYRB } & \text { Upper Yampa River Basin } \\ \text { WRTDS } & \text { Weighted Regressions on Time, Discharge, and Season } \\ \text { WY } & \text { water year }\end{array}$





\title{
Assessment of Streamflow and Water Quality in the Upper Yampa River Basin, Colorado, 1992-2018
}

\author{
By Natalie K. Day
}

\section{Abstract}

The Upper Yampa River Basin drains approximately 2,100 square miles west of the Continental Divide in northwestern Colorado. There is a growing need to understand potential changes in the quantity and quality of water resources as the basin is undergoing increasing land and water development to support growing municipal, industrial, and recreational needs. The U.S. Geological Survey, in cooperation with stakeholders in the Upper Yampa River Basin water community, began a study to characterize and identify changes in streamflow and selected water-quality constituents, including suspended sediment, Kjeldahl nitrogen, total nitrogen, total phosphorus, and orthophosphate, in the basin. This study used streamflow and water-quality data from selected U.S. Geological Survey sites to provide a better understanding of how major factors, including land use, climate change, and geological features, may influence streamflow and water quality.

Analysis of long-term (1910-2018) and short-term (1992-2018) records of streamflow at main-stem Yampa River and tributary sites indicate downward trends in one or more streamflow statistics, including 1-day maximum, mean, and 7-day minimum. Long-term downward trends in daily mean streamflow in April (22 percent overall) at Yampa River at Steamboat Springs, Colorado, correspond to observed changes in streamflow documented across western North America and the Colorado River Basin that are predominately associated with changes in snowmelt runoff and temperatures. During the short-term period of analysis, decreases in streamflow at main-stem Yampa River and some tributary sites are likely related to changes in consumptive use and reservoir management or, at sites with no upstream flow impoundments, changes in irrigation diversions and climate.

Concentrations of water-quality constituents were typically highest in spring (March, April, and May) during the early snowmelt runoff period as material that is washed off the land surface drains into streams. Highest concentrations occurred slightly later, in May, June, and July, at Yampa River above Stagecoach Reservoir, Colo., and slightly earlier, in February and March at Yampa River at Milner, Colo., indicating that these sites may have different or additional sources of phosphorus from upstream inputs. Yampa River at Milner, Colo., and Yampa River above Elkhead Creek, Colo., had the highest net yields of suspended sediment, Kjeldahl nitrogen, and total phosphorus, and are likely influenced by land use and erosion as the basins of both of these sites are underlain by highly erodible Cretaceous shales.

Upward trends in estimated Kjeldahl nitrogen and total phosphorus concentrations and loads were found at Yampa River at Steamboat Springs, Colo. From 1999 to 2018, the Kjeldahl nitrogen concentration increased by 10 percent or 0.035 milligram per liter, and load increased by 22 percent or 26 tons. Total phosphorus concentration increased by 20 percent or 0.0081 milligram per liter, and loads increased by 41 percent or 6.2 tons. Decreases in streamflow and changes in land use may contribute to these trends.

During multiple summer sampling events at Stagecoach Reservoir, the physical and chemical factors indicated conditions conducive to cyanobacterial blooms, including surfacewater temperatures greater than 20 degrees Celsius and total phosphorus and total nitrogen concentrations in exceedance of Colorado Department of Public Health and Environment interim concentrations for water-quality standards. Local geological features (predominately sandstones and shales) and additional inputs from upstream land use likely contribute to the elevated nutrient conditions in Stagecoach Reservoir.

\section{Introduction}

The Yampa River, in the Upper Colorado River Basin in northwestern Colorado, is the largest mostly free-flowing river in the Colorado River system. Because of limited reservoir storage, the river is known for its largely unaltered natural condition, biological diversity, and water quality, and is a valued multiuse resource in the Upper Yampa River Basin (UYRB; Bauch and others, 2012). The UYRB, as defined in this report, is the area of land drained by the Yampa River from its headwaters near the Flat Tops, a mountain range in Garfield County, to near Craig, Colorado (fig. 1). Table 1 provides information on the water-quality and streamgage sites shown in figure 1. 


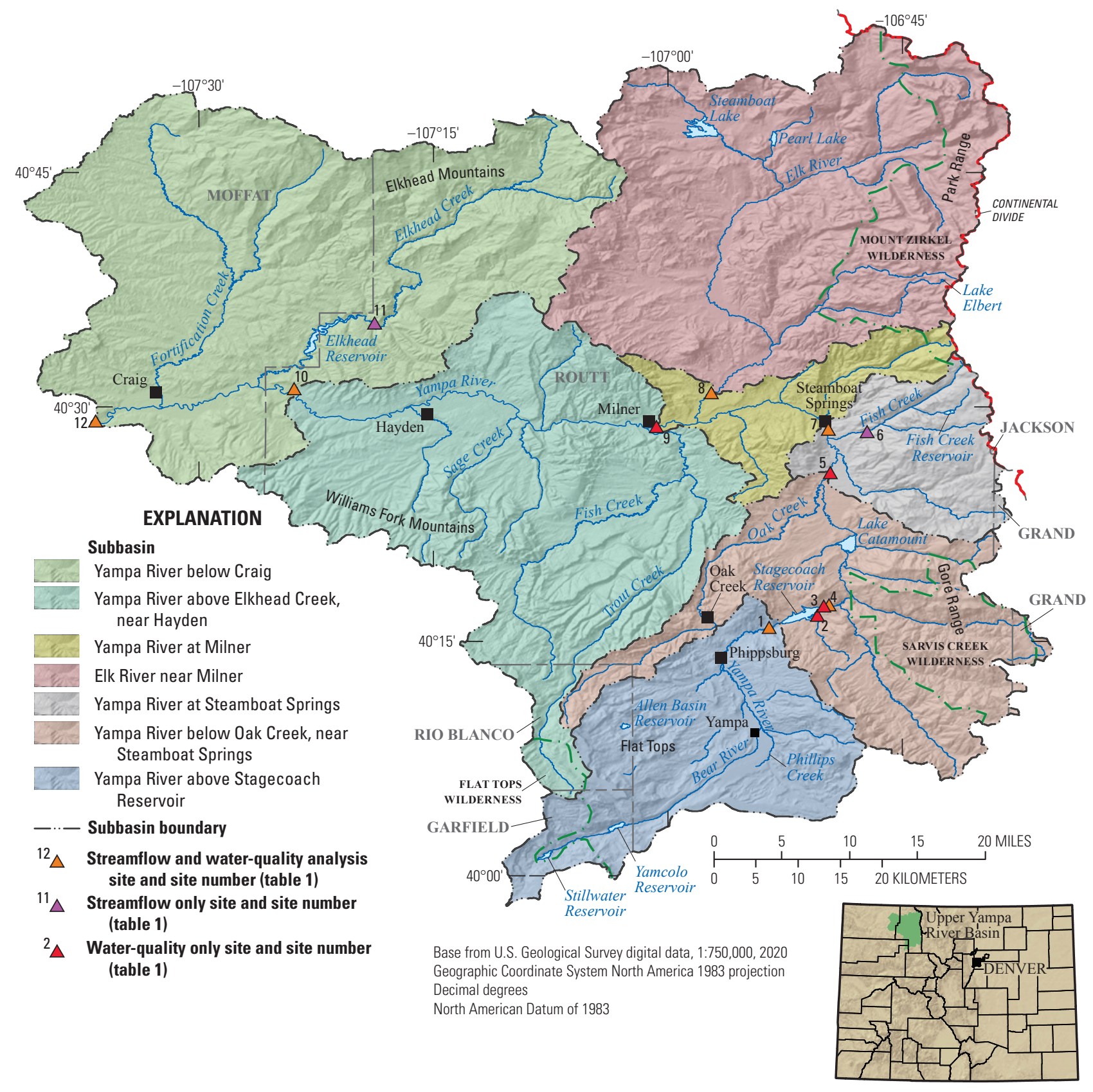

Figure 1. Map showing the location of the Upper Yampa River Basin, Colorado, with selected U.S. Geological Survey water-quality sites and water year 2018 streamgage sites. 
Table 1. Summary of U.S. Geological Survey (USGS) water-quality and streamgage sites in the Upper Yampa River Basin (UYRB), Colorado (CO), included in this report.

[USGS information from the USGS National Water Information System database (https://doi.org/10.5066/F7P55KJN). "Streamflow trends period of analysis" refers to climate years. A "climate year" is defined as a 12-month period beginning April 1 and ending March 31 of the following year and is designated as the year in which it begins. "Water-quality period of analysis" refers to water years. A "water year" is defined as a 12-month period beginning October 1 and ending September 30 of the following year and is designated as the year in which it ends. NA, not applicable]

\begin{tabular}{|c|c|c|c|c|c|}
\hline $\begin{array}{l}\text { Site number } \\
\text { (fig. 1) }\end{array}$ & USGS site number & USGS site name & $\begin{array}{l}\text { UYRB monitoring } \\
\text { program? }\end{array}$ & $\begin{array}{l}\text { Streamflow trends } \\
\text { period of analysis }\end{array}$ & $\begin{array}{l}\text { Water-quality period } \\
\text { of analysis }\end{array}$ \\
\hline 1 & 09237450 & $\begin{array}{l}\text { Yampa River above Stagecoach } \\
\text { Reservoir, CO }\end{array}$ & Yes & $1992-2018$ & $2010-18^{\mathrm{a}}$ \\
\hline 2 & 401634106502200 & $\begin{array}{l}\text { Little Morrison Creek near } \\
\text { Stagecoach, CO }\end{array}$ & No & NA & $2012-14,2017-18^{\mathrm{b}}$ \\
\hline 3 & 401707106495800 & Stagecoach Reservoir at Dam, CO & No & NA & $2012-18^{\mathrm{b}}$ \\
\hline 4 & 09237500 & $\begin{array}{l}\text { Yampa River below Stagecoach } \\
\text { Reservoir, CO }\end{array}$ & No & 1992-2018 & $2010-18^{\mathrm{b}}$ \\
\hline 5 & 402544106493600 & $\begin{array}{r}\text { Yampa River below Oak Creek } \\
\text { near Steamboat Springs, } \text { CO }^{c}\end{array}$ & Yes & NA & $2010-18^{\mathrm{a}}$ \\
\hline 6 & 09238900 & $\begin{array}{l}\text { Fish Creek at Upper Station } \\
\text { near Steamboat Springs, CO }\end{array}$ & No & 1992-2018 & NA \\
\hline 7 & 09239500 & $\begin{array}{l}\text { Yampa River at Steamboat } \\
\text { Springs, CO }\end{array}$ & Yes & $1910-2018$ & $1999-2018^{\mathrm{a}}$ \\
\hline 8 & 09242500 & Elk River near Milner, $\mathrm{CO}^{\mathrm{d}}$ & Yes & 1992-2018 & $2010-18^{\mathrm{a}}$ \\
\hline 9 & 402840107004200 & Yampa River at Milner, $\mathrm{CO}^{\mathrm{c}}$ & Yes & NA & $2010-18^{\mathrm{a}}$ \\
\hline 10 & 09244490 & $\begin{array}{l}\text { Yampa River above Elkhead } \\
\text { Creek near Hayden, CO }\end{array}$ & Yes & 1992-2018 & $2010-18^{\mathrm{a}}$ \\
\hline 11 & 09246200 & $\begin{array}{l}\text { Elkhead Creek above Long Gulch } \\
\text { near Hayden, CO }\end{array}$ & No & 1996-2018 & NA \\
\hline 12 & 09247600 & Yampa River below Craig, CO & No & $1992-2018$ & $1999-2018^{\mathrm{a}}$ \\
\hline
\end{tabular}

${ }^{a}$ Water-quality analysis including regression (concentrations, loads, and streamflow-normalized loads and yields) and trend analysis.

${ }^{\mathrm{b}}$ Water-quality analysis using discrete data only.

'Site is missing continuous streamflow data, and an estimated hydrograph was created; limitations are discussed in "Extension of Streamflow Record" section.

${ }^{\mathrm{d}}$ Site is missing streamflow data from January 1 to April 31 during water years 2008-12, and an estimated hydrograph was created; limitations are discussed in "Extension of Streamflow Record" section.

In 2012, the U.S. Geological Survey (USGS) published an analysis of water-quality data in the UYRB for 1975-2009 (Bauch and others, 2012). The USGS concluded that concentrations of constituents in surface water are likely controlled primarily by geological features, streamflow, and land use, but that additional streamflow data were needed to assess the effects of land use and geological features on observed water quality in the basin. Analysis of changes in water quality over time was limited because of the absence of long-term data collected in the UYRB (Bauch and others, 2012). In response to these information gaps, the USGS and local stakeholders established a comprehensive long-term water-quality monitoring program for the UYRB in October 2010, which continues to the present day (2020). Six sites in the monitoring program (table 1) were selected for this study as representative of different geologic and land-use types in the UYRB to enhance understanding of how these factors influence water quality.
In recent years, Colorado Department of Public Health and Environment (CDPHE) interim concentrations for water-quality standards (Regulation No. 31; CDPHE, 2017) and concerns related to algae blooms in Stagecoach Reservoir have become important topics to local stakeholders (Halliday, 2016). The potential for cyanobacterial blooms and elevated phosphorus concentrations have been documented since the completion of the Stagecoach Reservoir in 1993 (Bureau of Reclamation, 1986). Cyanobacterial blooms in Stagecoach Reservoir have been observed with increasing frequency in the past several years (2015-18), and there have been anecdotal reports by residents and land managers of blooms in the main stem of the Yampa River below Stagecoach Reservoir, drawing additional interest from stakeholders. Direct and indirect effects of land use, hydrology, and climate change can exacerbate conditions that favor bloom-forming algae, some 
of which can produce toxins that are harmful to humans and animals, degrade water quality, and decrease water supply (Paerl and Otten, 2013).

In 2019, the USGS, in cooperation with stakeholders in the water community, began this study to evaluate temporal and spatial trends in streamflow, water temperature, and water-quality data in the basin. Water-quality data include suspended sediment, Kjeldahl nitrogen, total nitrogen, total phosphorus, orthophosphate, dissolved oxygen, planktonic algal densities, and algal toxin concentrations for streams and Stagecoach Reservoir. The involved stakeholder groups are the Upper Yampa River Watershed Group, Upper Yampa Water Conservancy District, Colorado Water Conservation Board, Yampa-White-Green Basin Roundtable, Mount Werner Water and Sanitation District, Routt County, and the city of Steamboat Springs. This analysis provides an enhanced understanding of water resources for the region and highlights potential impairments to water supply and the ecological health of the basin. This study utilized streamflow and water-quality data collected by the USGS to characterize and identify changes in streamflow and selected water-quality constituents in the UYRB.

\section{Purpose and Scope}

This report describes an assessment of streamflow and water-quality data in the UYRB in Colorado during 1992-2018. The time periods for analysis and site selections were done to provide a better understanding of how major factors, including land use and geological features, may contribute to trends in streamflow and water quality in the UYRB study area. This report includes a summary of these results, which may facilitate resource management decisions regarding water supply, water quality, and algal-sourced toxicity concerns. This report (1) describes seasonal variation and temporal trends in streamflow, suspended sediment, and nutrient concentrations and loads; (2) provides comparisons of nutrient concentrations to State of Colorado interim concentrations for water-quality standards; (3) identifies subbasins with higher suspended sediment and nutrient yields; (4) summarizes water temperature, water-quality and algal data for Stagecoach Reservoir; and (5) describes land-cover changes in the basin.

\section{Previous Studies}

Several studies have investigated streamflow and water quality in the UYRB. Tobin (1996) assessed the initial effects of the construction and filling of Stagecoach Reservoir on the hydrology of the Upper Yampa River. The study examined physical, chemical, and biological data collected from 1988 to 1991 at sites upstream and downstream from the reservoir and in the reservoir. Cyanobacteria blooms of Aphanizomenon sp. and Aphanocapsa sp. were measured in the reservoir during 1990-92.

The USGS has studied the water quantity and quality, and aquatic ecology, of the Upper Yampa River watershed (Bauch and others, 2012). The Bauch study (2012) summarized available water-quality, water-quantity, and aquatic-ecology data collected from 1975 to 2009 by various agencies for streams, lakes, reservoirs, and groundwater. Bauch and others (2012) found a statistically significant upward trend in total phosphorus concentration at Yampa River at Steamboat Springs, Colo. (USGS site number 09239500), herein referred to as "Yampa River at Steamboat Springs." Bauch and others (2012) indicated that population growth and land-use changes may have contributed to the trend.

The Upper Yampa River Watershed Plan (Halliday, 2016) was initiated by the Upper Yampa Watershed Group in 2013. The purpose of the plan is to increase local partnerships and their capacity to protect and enhance water quality, promote water conservation, and sustain and improve the present health of the basin.

\section{Description of the Study Area}

The UYRB drains approximately 2,100 square miles of the Yampa River Basin west of the Continental Divide in northwestern Colorado (fig. 1). The boundaries of the basin extend from the Williams Fork and the Flat Tops in the southwestern and southern parts of the basin, respectively, to the Gore and Park Ranges and the Continental Divide to the east and to the Elk River and Fortification Creek drainages to the north and west, respectively. Elevations in the basin range from more than 12,000 feet (ft) (above North American Vertical Datum of 1988) in the Flat Tops and Park Range to $6,100 \mathrm{ft}$ (above North American Vertical Datum of 1988) near the confluence of the Yampa River with Fortification Creek south of the city of Craig. Most of the UYRB is within Routt County, with small parts in Grand, Garfield, Jackson, Moffat, and Rio Blanco Counties.

The population of Routt County during 2018 was estimated to be 25,733 (U.S. Census Bureau, 2020). The population of the county grew by more than 9.5 percent from 2010 through 2018, and the growth was largely driven by recreation-related tourism. The largest municipality in the UYRB is Steamboat Springs (13,212 residents) and the next largest is Craig ( 8,888 residents).

For the greater part of the past century, ranching, including hay and wheat production, and mining were the economic base of the Yampa River Valley. More recently, recreationbased tourism, including skiing, fishing, hunting, rafting, and camping, and second-home development, became economic drivers. Tourism accounted for approximately 37 percent of 
the total jobs in Routt County during 2018, whereas mining and agriculture accounted for only about 7 percent of the total jobs during the same year (Colorado State Demography Office, 2018). During 2018, tourism accounted for only 8 percent of the total jobs in Moffat County, whereas mining and agriculture accounted for 25 percent of the total jobs (Colorado State Demography Office, 2018).

Temperature and precipitation in the UYRB are typical of that found in other mountainous and semiarid regions of Colorado. Mean temperatures in the cities of Steamboat Springs and Craig range from minimum temperatures of 3.2 and 6.6 degrees Fahrenheit $\left({ }^{\circ} \mathrm{F}\right)$, respectively, during January, to maximum temperatures of 82.6 and $85.3^{\circ} \mathrm{F}$, respectively, during July from 1977 to 2020 (High Plains Regional Climate Center, 2020). On average, almost 25 inches per year (in/ yr) of precipitation falls in Steamboat Springs, and $16.5 \mathrm{in} /$ yr falls in Craig. Much of the precipitation is snow during winter months. Snowfall means are $181 \mathrm{in} / \mathrm{yr}$ in Steamboat Springs and $77 \mathrm{in} / \mathrm{yr}$ in Craig (High Plains Regional Climate Center, 2020).

Much of the UYRB is underlain by sedimentary rocks of Cretaceous age, including sandstones, shales, and major coal beds (fig. 2). Less resistant shales in the form of broad valleys and small rounded hills are found in the western two-thirds of the basin and with more resistant sandstones found in areas as ridges and mesas (Bauch and others, 2012).

\section{Hydrology and Water Use}

The Yampa River originates in the Flat Tops as the Bear River, flows northward to the town of Yampa, Colo., and becomes the Yampa River where Phillips Creek converges with the Bear River (fig. 1). Major tributaries to the Yampa River include Oak Creek, upstream from Steamboat Springs; the Elk River, downstream from Steamboat Springs; and Elkhead Creek, downstream from Hayden, Colo. Minor tributaries include Fish Creek east of Steamboat Springs, Trout Creek, Sage Creek, and Fortification Creek.

Streamflow in the UYRB is dominated by snowmelt runoff; streamflows increase in April, peak in May and June, and decrease in July (USGS, 2020). Streamflow from August through March is often dominated by base flow from groundwater discharge and supplementation from reservoirs. Mean monthly streamflow for water years (WYs) 2013 through 2018 for 2 sites on the Yampa River and 1 site on the Elk River show seasonal patterns of streamflow (fig. 3). A WY is the 12-month period from October 1 through September 30 and is designated by the year in which it ends.
Surface water in the UYRB is utilized for multiple uses. The principal use of water is for irrigation, and irrigation ditches divert water from the Yampa River and tributary streams throughout the basin. The ditch water is used primarily to irrigate hay and alfalfa crops and pasture lands. Total surface-water withdrawals for irrigation purposes in Routt and Moffat Counties were 171 and 121 million gallons per day in 2015, respectively (Dieter and others, 2018).

The city of Steamboat Springs Utilities Division and the Mount Werner Water and Sanitation District divert most of their municipal water supplies directly from Fish Creek east of Steamboat Springs (AECOM and Colorado Water Conservation Board, 2009). Water can be released from Fish Creek Reservoir for augmentation when flow in the creek is insufficient for supply. These two municipal water suppliers can also withdraw water from alluvial wells adjacent to the Yampa River; however, these wells are not a preferred source of municipal water because the quality of the water is considered to be inferior to that of the surface-water supplies (AECOM and Colorado Water Conservation Board, 2009). The city of Craig diverts most of its municipal water from the Yampa River upstream from Fortification Creek. Surface water is the primary water source for the towns of Hayden and Oak Creek, whereas groundwater is the primary water source for towns of Phippsburg and Yampa and part of the source for Hayden (Topper and others, 2006).

The nine largest reservoirs in the UYRB, each with storage capacity greater than $(>)$ 4,000 acre-feet, store water that is used for irrigation, recreational, and municipal purposes (AECOM and Colorado Water Conservation Board, 2009). Stillwater Reservoir No. 1, Allen Basin Reservoir, and Yamcolo Reservoir store water primarily for irrigation; Lake Catamount, Pearl Lake, and Steamboat Lake are predominantly used for recreation and fishing; Fish Creek Reservoir stores water for municipal use; and Stagecoach Reservoir and Elkhead Reservoir store water for multiple purposes, including municipal, industrial, irrigation, and recreation (fig. 1). Stagecoach Reservoir, upstream from Steamboat Springs on the Yampa River, is the largest storage facility in the UYRB with a total capacity of approximately 36,500 acre-feet. Allocation of water from the Stagecoach Reservoir includes approximately 18,000 acre-feet for recreation and dead-pool storage, 11,000 acre-feet for industrial water, and 2,000 acre-feet for municipal water. An additional 2,000 acre-feet is unallocated water for municipal and industrial purposes (AECOM and Colorado Water Conservation Board, 2009). The dam at Stagecoach Reservoir supports a hydroelectric power station, and the dam and reservoir are owned and operated by the Upper Yampa Water Conservancy District. There are no main-stem reservoirs downstream from Steamboat Springs. 


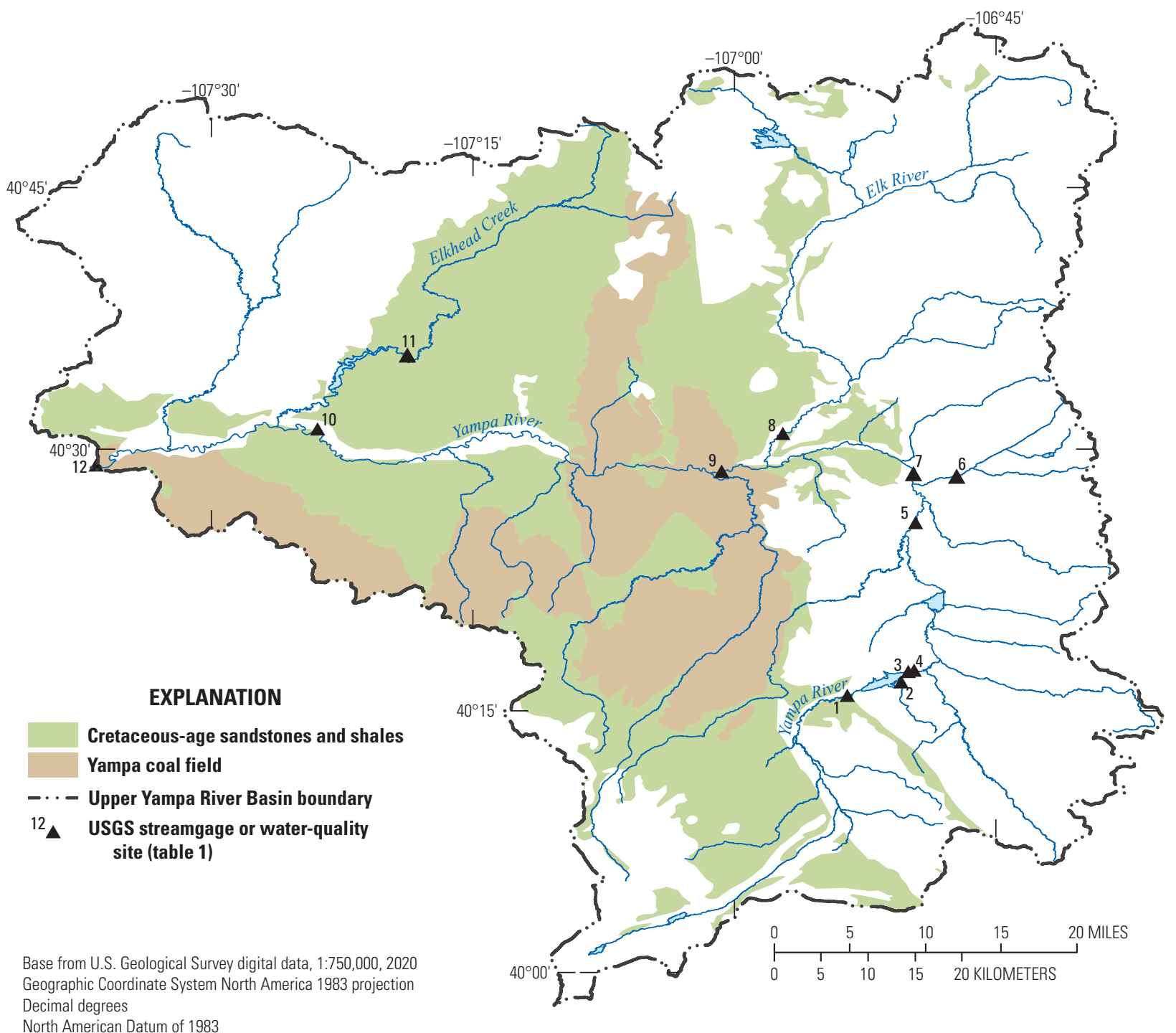

Figure 2. Map showing Cretaceous-aged sandstones, shales, and major coal beds of the Upper Yampa River Basin, Colorado. Modified from Tweto (1979) and Kirschbaum and Biewick (2000). (USGS, U.S. Geological Survey) 


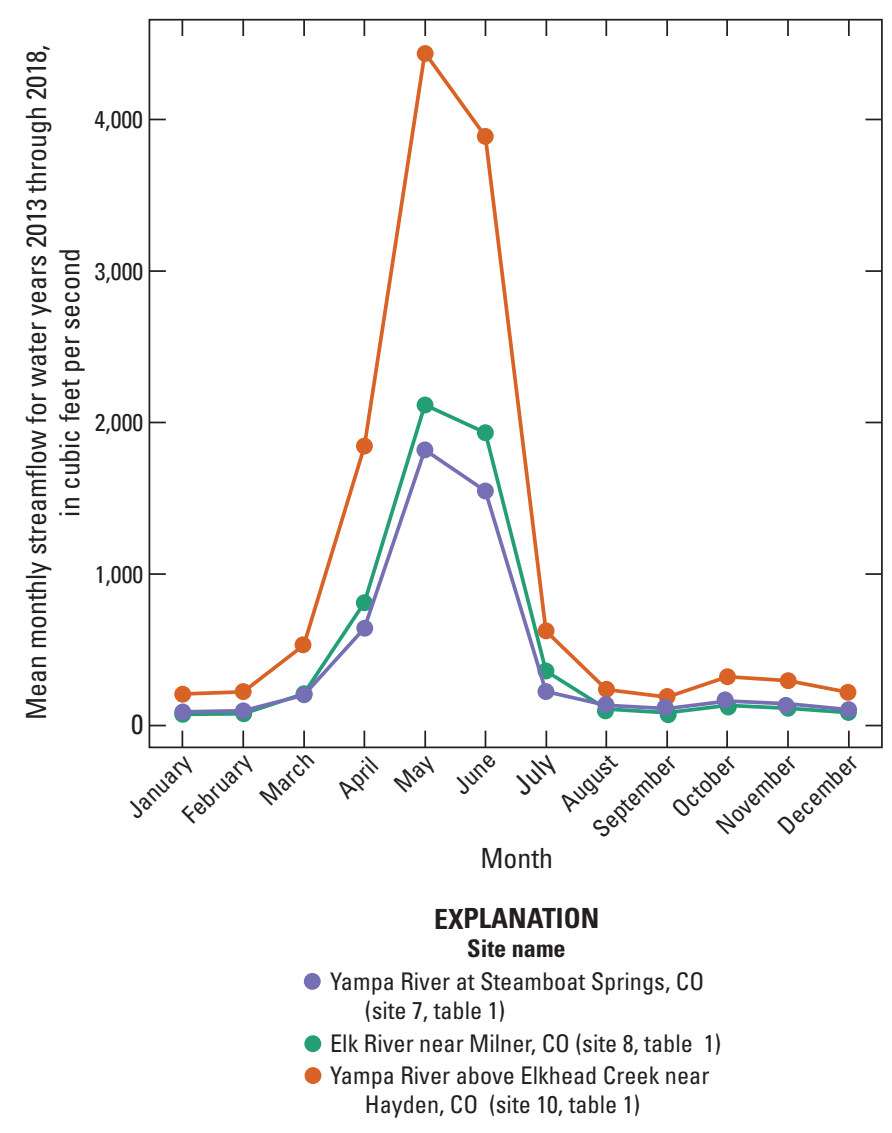

Figure 3. Graph showing the mean monthly streamflow, in cubic feet per second, at selected streamgage sites in the Upper Yampa River Basin, Colorado (CO), for water years 2013 through 2018.

\section{Approach and Methods}

The approach of this study was to characterize and identify changes in streamflow and selected water-quality constituents in the UYRB. The constituents of interest were selected for analysis in consultation with local stakeholders. The nature and extent of changes in streamflow were examined. Statistical models were used to estimate concentrations and loads for suspended sediment, nitrogen, and phosphorus. Nitrogen and phosphorus concentrations were compared to State of Colorado interim concentrations for water-quality standards. Streamflow-normalized loads and yields were used to compare water quality across sites and identify source areas of loading. Trends in concentration and load were examined. Selected physical, chemical, and biological characteristics of Stagecoach Reservoir were assessed. Changes in land use in the UYRB were assessed using spatial data. All data analysis was performed in $\mathrm{R}$ (R Core Team, 2020).

\section{Data Compilation and Quality Assurance}

This study analyzed data collected and processed by the USGS following USGS methods to assess streamflow and water-quality conditions in the UYRB. Streamflow data were collected and processed according to the methods in Turnipseed and Sauer (2010). Water-quality data were collected following USGS protocols in the USGS National Field Manual (USGS, variously dated). Data for most water-quality constituents for streams were collected quarterly to capture seasonal changes in concentrations related to changes in streamflow (for example, spring runoff, summer base flow). Water-quality data from Stagecoach Reservoir were collected once a month from July to September in 2017 and 2018.

Data for water-quality constituents are reported as filtered (through a 0.45 -micron filter, dissolved) or unfiltered. Data may also be reported as total; for example, total nitrogen includes all chemical species of nitrogen. Total nitrogen represents all inorganic and organic species of nitrogen present in a stream and is a calculated value that comprises separate 
measures of inorganic and organic chemical species. At the sites considered in this study, total nitrogen was calculated as the sum of unfiltered nitrite plus nitrate and unfiltered Kjeldahl nitrogen (organic nitrogen plus ammonia), herein referred to as "Kjeldahl nitrogen." At multiple sites in this study, $>50$ percent of total nitrogen values were censored, meaning that either one or both of the constituents used to calculate total nitrogen were reported as "less than" the long-term method detection level concentration. Most regression techniques require less than $(<) 50$ percent of data to be censored. Therefore, Kjeldahl nitrogen was used as a surrogate for total nitrogen in regression models and trend analysis. Use of Kjeldahl nitrogen will preclude detection of trends in inorganic nitrogen. Discrete data for all constituents displayed in this report are reported either as "discrete concentration," which is the uncensored discrete data (uncensored); "discrete $(<)$ concentration," which refers to censored values that are less than $(<)$ the long-term method detection level concentration; or "discrete (E) concentration," which refers to estimated values between the laboratory reporting level and the method detection level up to 2010 (Oblinger Childress and others, 1999). After 2010, a remark code of "E" was no longer assigned and concentrations that are less than the long-term method detection level concentration are reported as "less than" $(<)$ (USGS, 2010). All USGS discrete water-quality and continuous streamflow data are reviewed and approved on a regular interval by qualified USGS personnel. All USGS data used in this report have been approved for publication.

For this study, the selected USGS data underwent quality assurance checks, and the quality-checked data were used in regression models, compared to CDPHE interim concentrations for water-quality standards, and analyzed for temporal trends. The following discussion describes the methods used to retrieve, evaluate, and analyze streamflow and water-quality data for the UYRB.

Streamflow data and data for suspended sediment, nitrogen (unfiltered total nitrogen and unfiltered Kjeldahl nitrogen) and phosphorus (unfiltered total phosphorus and filtered orthophosphate) were retrieved in an electronic format from the USGS National Water Information System (NWIS; USGS, 2020) database. Streamflow and water-quality data were obtained for 6 main-stem Yampa River sites (table 1, sites $1,4,5,9,10$, and 12), 4 tributary sites (table 1, sites 2 , 6,8 , and 11 ), and 1 reservoir site (table 1 , site 3 ) for selected periods from 1992 to 2018, and for 1 main-stem Yampa River site (table 1, site 7) for the full period of record, 1910-2018. Water-quality data, including chlorophyll a, water temperature, dissolved oxygen, and algal toxin concentrations, were obtained for one reservoir site from the USGS NWIS database (USGS, 2020). Other algal data, including taxonomic identification and abundance for phytoplankton samples for the reservoir site are available from a USGS data release (Solberg, 2020).
Time periods were selected for analysis to capture the effects of reservoir construction, maximize comparability among sites, and limit the use of censored data. The year 1992 was chosen as the starting year for streamflow trend analysis because construction of a major reservoir, Stagecoach Reservoir, was completed and the reservoir was filled to spillway capacity by that time (Tobin, 1996). The period of analysis for water-quality data for five stream sites began in April 2010 when the UYRB Monitoring Program was initiated. The period of analysis varies for sites not in the monitoring program. The period of analysis at two sites, Yampa River at Steamboat Springs and Yampa River below Craig, CO (USGS site number 09247600), herein referred to as "Yampa River below Craig," began in WY 1999 to avoid using excessive censored data in regression analyses (table 1).

\section{Extension of Streamflow Record}

To estimate daily streamflow at sites with only a partial record, the Maintenance of Variance Extension Type 2 (MOVE.2) regression technique was used to correlate streamflow at the site of partial record with concurrent streamflow at a nearby streamgage (Hirsch, 1979). The record resulting from the MOVE. 2 regression technique is herein referred to as "estimated hydrograph." If data between sites with partial streamflow records and sites with complete streamflow records are correlated, the coefficients produced from a linear regression can be used to predict missing streamflows at the site with a partial record.

Sites with partial daily streamflow record requiring a MOVE. 2 regression technique to estimate missing records include Elk River near Milner, CO (USGS site number 09242500), herein referred to as "Elk River near Milner," Yampa River below Oak Creek near Steamboat Springs, CO (USGS site number 402544106493600), herein referred to as "Yampa River below Oak Creek," and Yampa River at Milner, CO (USGS site number 402840107004200), herein referred to as "Yampa River at Milner." Streamflow data missing at Elk River near Milner from January 1-April 31 during WYs 2008-12 were estimated using continuous streamflow at Yampa River at Steamboat Springs.

For Yampa River below Oak Creek and Yampa River at Milner, only discrete values of streamflow measured during collection of water-quality samples were available (USGS, 2020). A continuous streamflow record was estimated at Yampa River below Oak Creek using the relation between discrete streamflows at that site and the continuous streamflow measured at Yampa River at Steamboat Springs minus the streamflow measured at Fish Creek at Upper Station near Steamboat Springs, CO (USGS site number 09238900). Likewise, a continuous streamflow record was estimated at Yampa River at Milner using the relation between discrete streamflow at that site and the cumulative continuous streamflow measured at Yampa River at Steamboat Springs 
and Elk River near Milner. All model fits (coefficient of determination $\left[R^{2}\right]$ ) were $>0.95$ and met the assumptions of the MOVE. 2 analysis. Input and output streamflows associated with the MOVE. 2 analysis are included in the data release (Day, 2021). Because of the large proportion of streamflow data estimated, Yampa River at Milner and Yampa River below Oak Creek were not included in the streamflow trend analysis. These sites were used in regression equations to estimate concentrations and loads; however, interpretation of these results warrants a higher degree of caution because errors in the estimated hydrograph will be propagated into concentration and load calculations.

\section{Streamflow Trend Analysis}

To explore the nature and extent of changes in streamflow in the UYRB, this study reviewed temporal changes in daily streamflow statistics for 5 main-stem Yampa River sites and 3 tributary sites on an annual and monthly basis. The time period of analysis for assessing trends in streamflow extended from climate year (CY) 1992, when the Stagecoach Reservoir was completed, to CY 2018. A CY is defined as a 12-month period beginning April 1 and ending March 31 of the following year and is designated as the year in which it begins. Climatic years are used in streamflow trend analysis to avoid breaking a long low-flow period (that is, November to February) into two segments. Elkhead Creek above Long Gulch near Hayden, CO (USGS site number 09246200), herein referred to as "Elkhead Creek above Long Gulch," had a slightly shorter time period of analysis, from CY 1996 through CY 2018. Streamflow trends were examined across a longer time scale at Yampa River at Steamboat Springs, from CY 1910 through CY 2018, to examine long-term trends in streamflow. Streamflow statistics included 1-day maximum, mean, and 7-day minimum, and were assessed using the R package Estimation of Graphics for RivER Trends, also known as EGRET (Hirsch and De Cicco, 2015). Trend slopes were calculated using the ThielSen slope estimator and expressed as percentage changes per decade (Hirsch and De Cicco, 2015). The statistical strength of the trends was assessed using the Mann-Kendall trend test, and 90-percent confidence intervals were used to determine significance.

Changes in timing of peak streamflow were also assessed at Yampa River at Steamboat Springs from WY 1910 through WY 2018. The mean date of peak streamflow was obtained by averaging dates of peak streamflow obtained from NWIS (USGS, 2020) across the period of analysis. Deviation from the mean peak streamflow date was calculated as the difference between the peak streamflow date for each year from the mean peak streamflow date for the period of analysis. Linear regression was used to look for trends in deviation of peak streamflow date from the long-term mean, where a downward slope would correspond to an earlier peak streamflow date.

\section{Concentration and Load Estimates}

Multilinear regression techniques were used to estimate concentrations and loads of suspended sediment and nutrient constituents at sites that met selection criteria, including sample period of record, sample density, and percentage of data censored. Seven sites met the criterion of having a minimum of 8 years of water-quality data with at least 20 observations (Runkel and others, 2004). Regression models define the relation between the concentration of a selected water-quality constituent and explanatory variables, such as daily mean streamflow, seasonality, and time (Cohn, 2005; Helsel and others, 2020). Each explanatory variable explains part of the variation in the response variable. The regression model used to calculate daily concentrations and loads was developed using the R-LOADEST program (Lorenz and others, 2015), which is an R-based version of the USGS statistical program LOAD ESTimator (LOADEST; Runkel and others, 2004). R-LOADEST uses up to six explanatory variables to build a regression model that defines the relation of a constituent to streamflow, time, and season. The general form of the multiple linear regression model is as shown in equation 1 :

$\ln C=b_{0}+b_{1}\left(\ln Q-\ln Q^{*}\right)+b_{2}\left(t-t^{*}\right)+b_{3}(\sin (2 \pi T))+b_{4}(\cos (2 \pi T))+e,(1)$

where

$\ln \quad$ is the natural log;

$C$ is the constituent concentration, in milligrams per liter;

$b_{0} \quad$ is the regression equation intercept;

$b_{\mathrm{n}} \quad$ is the coefficient on the $n$th regression variable, where $n$ is 1 through 4;

$Q \quad$ is a streamflow term, in cubic feet per second;

$Q^{*} \quad$ is the streamflow centering value, in cubic feet per second;

$t$ is time, in decimal years;

$t^{*} \quad$ is the time centering value from the calibration dataset, in decimal years;

$\sin$ is the sine function;

$\pi \quad$ is 3.14159;

$T \quad$ is the decimal part of the year starting

January 1 ;

$\cos$ is the cosine function; and

$e \quad$ is the error associated with the regression equation.

Loads were calculated by multiplying sample concentrations or regression estimates by daily mean streamflow and a unit conversion constant. Concentration and streamflow values were $\log$ transformed to meet the assumptions of normality and constant variance (Hirsch and others, 1991). Streamflow and decimal time were centered around their means to reduce the likelihood of multicollinearity and to ensure orthogonality in the streamflow and decimal time variables (Cohn and 
others, 1992). A Fourier series was used to account for differences in seasonal load (Runkel and others, 2004; Cohn, 2005). A Fourier series uses sine and cosine functions to describe continual change over the seasonal period. Model coefficients were estimated using adjusted maximum likelihood estimation, which is designed to correct for bias caused by the inclusion of censored data (Runkel and others, 2004).

The final model equations were selected by comparing Akaike Information Criteria scores, diagnostic plots, and statistics (Runkel and others, 2004) that are used to indicate whether the model fit met the assumptions of multilinear regression (Helsel and others, 2020). A consistent model form was used among sites where Fourier series and decimal time were retained at an alpha of 0.05 , and the streamflow variable was always included to facilitate comparison among sites. The adjusted $R^{2}$ indicates how much variance in the response variable is explained by the regression model (Helsel and others, 2020). Values of adjusted $R^{2}$ closer to 1.0 indicate that more of the variance is being explained by the model compared to values closer to 0.0 , which indicate that less of the variance is being explained by the model. Regression analysis was performed on water-quality data at 2 sites for WYs 1999-2018 and at 5 sites for WYs 2010-18 (table 1). All input and output data associated with the regression analysis are included in the data release (Day, 2021).

\section{Comparison to Interim Concentrations for Water-Quality Standards}

Estimated daily concentrations of nitrogen and phosphorus, as well as annual median concentrations calculated from estimated daily concentrations, were compared to State of Colorado interim water-quality standards for nitrogen and phosphorus concentrations. Instream water-quality standards for surface water in Colorado have been established by the CDPHE to protect the beneficial uses of surface water, which include support of aquatic life, and use for domestic water supply, agriculture, and recreation (CDPHE, 2017). In 2012, Regulation No. 31-The Basic Standards and Methodologies for Surface Waters was revised to include interim concentrations for total nitrogen, total phosphorus, and chlorophyll $a$ for rivers and streams, and lakes and reservoirs (table 2). Estimated daily and median concentrations for 7 stream sites and discrete concentrations at 1 stream site and 1 reservoir site in the UYRB were compared to CDPHE interim concentrations for nitrogen and phosphorus for cold water.

\section{Normalized Mean Daily Streamflows, Loads, and Yields}

Normalized mean daily streamflows, loads, and yields were estimated for seven sites in the UYRB (table 1). Daily mean streamflow values for a site were averaged to produce a mean daily streamflow for each day of the calendar year during the period of analysis for that site. An averaging function available on the National Water Information System website (https://waterdata.usgs.gov/co/nwis/dvstat/) was used to calculate the normalized mean daily streamflow. At sites with an estimated hydrograph, the averaging was performed in R. For example, the mean daily streamflow for January 1, 2010-18, at Elk River near Milner was calculated from each January 1 value from the beginning of the analysis period through the end of the analysis period (2010-18). Calculating a mean daily streamflow for every day of the year removes differences in the year-to-year fluctuations in daily streamflow and allows estimates of annual load for water-quality constituents (Helsel and others, 2020). Regression models using the mean daily streamflows were used to predict annual loads at each of the seven sites. All input and output data associated with the regression analysis are included in the data release (Day, 2021).

Relative yields were calculated for seven subbasins (fig. 1) by dividing the regression-based estimates of annual load at each site by the total subbasin area contributing to that site, after excluding all upstream subbasin loads and basin areas. The normalized loads and yields can be used to assess the influence of land-use activities, population, and water consumption on water quality.

Table 2. Colorado Department of Public Health and Environment (CDPHE) interim concentrations for total nitrogen, total phosphorus, and chlorophyll a water-quality standards for surface water in the Upper Yampa River Basin, Colorado (CDPHE, 2017).

[mg/L, milligrams per liter; $\mathrm{mg} / \mathrm{m}^{2}$, milligrams per square meter; $\mu \mathrm{g} / \mathrm{L}$, micrograms per liter $]$

\begin{tabular}{ccc}
\hline Constituent & Cold rivers and streams & Cold lakes and reservoirs \\
\hline Total nitrogen & $1.25 \mathrm{mg} / \mathrm{L}^{\mathrm{a}}$ & $0.426 \mathrm{mg} / \mathrm{L}^{\mathrm{b}}$ \\
Total phosphorus & $0.11 \mathrm{mg} / \mathrm{L}^{\mathrm{a}}$ & $0.025 \mathrm{mg} / \mathrm{L}^{\mathrm{b}}$ \\
Chlorophyll $a$ & $150 \mathrm{mg} / \mathrm{m}^{2 \mathrm{c}}$ & $8.0 \mu \mathrm{g} / \mathrm{L}^{\mathrm{b}}$ \\
\hline
\end{tabular}

\footnotetext{
${ }^{a}$ Annual median, allowable exceedance frequency 1-in-5 years.

${ }^{\mathrm{b}}$ Summer (July 1-September 30) mean in the mixed layer of the lakes (median of multiple depths), allowable exceedance frequency 1-in-5 years.

${ }^{\mathrm{c}}$ Summer (July 1-September 30) maximum attached algae, not to exceed.
} 


\section{Concentration and Load Trend Analysis}

Characterizing long-term changes (trends) in waterquality constituents can provide insight regarding changes in land use and climate. Trends can be compared among sites across a common time period. A trend is often presented as a percentage change per year, or change in concentration (milligrams per liter [mg/L]) or load (tons) per year, and is described by the direction of change, either upward or downward. Two different methods were used to assess trends in water quality as a function of data availability. Trends in concentrations and loads of suspended sediment, nitrogen, and phosphorus were assessed using multiple linear regression models at seven sites. An additional method for assessing trends, using a weighted regression technique, was applied at two sites that met the requirements for such analysis.

\section{Multiple Linear Regression Trend Analysis}

Multiple linear regression techniques can be used to estimate long-term changes in mean concentrations and loads of water-quality constituents during a designated time scale. The coefficients of a regression model describe the size and direction of the relation between a predictor and the response variable (Helsel and others, 2020). Thus, the presence of a significant time coefficient was interpreted to indicate a temporal trend (either upward or downward) in concentration and load. A significance level $(\alpha)$ of 0.1 was applied to the time coefficient for inclusion in the regression model.

\section{Weighted Regression Trend Analysis}

The Weighted Regressions on Time, Discharge, and Season (WRTDS) method (Hirsch and De Cicco, 2015) was used to assess trends in Kjeldahl nitrogen and total phosphorus concentrations and loads at Yampa River at Steamboat Springs and Yampa River below Craig. These 2 sites were the only sites that met the recommended criterion for using WRTDS, which is a minimum of 60 observations and sampling that sufficiently represents seasonal variation in concentration and streamflow, such as that obtained with quarterly sampling (Hirsch and De Cicco, 2015). Concentration is modeled in WRTDS using the same equation used in LOADEST (eq. 1). Estimates of daily load are made by multiplying estimates of daily concentration by the respective daily mean streamflow. In most modeling approaches, including LOADEST, the fitted coefficients are constants that are estimated to produce the best fit to the entire sample of measured concentrations. In contrast, the WRTDS model estimates a unique set of coefficients for every combination of $Q$, the streamflow term, and $t$, time, in the period of record. The coefficients are fit by weighted regression, which bases coefficients more heavily on observations collected under conditions that are similar to those on the day for which an estimate is sought. The degree of similarity and, thus, weight on each observation, is based on their similarity in terms of time, streamflow, and season to the day being calibrated. The variable-parameter weighted-regression approach allows WRTDS to represent complex relations between concentration and streamflow at a site, as well as complex trends over time.

Because estimates of daily concentration and load are strongly influenced by random variations in streamflow, WRTDS also produces flow-normalized estimates of daily concentration and load for a site. The flow-normalized estimates remove variations in concentration or load resulting from random streamflow variations but not variations from nonrandom seasonal streamflow variations. See Hirsch and De Cicco (2015) for more details.

Confidence intervals on trend analysis were obtained using the WRTDS Bootstrap Test, which is a block bootstrap approach that uses a set of Monte Carlo simulations to estimate Type I error probability (that is, the probability of detecting a trend when a trend is not present; Hirsch and others, 2015). The WRTDS Bootstrap Test output includes (1) hypothesis tests for trend flow-normalized concentration and flow-normalized load (reject or do not reject the null hypothesis at alpha =0.1), (2) p-values for those tests, (3) 90-percent confidence intervals for the magnitude of the trend in flownormalized concentration and flow-normalized load, and (4) likelihood statements (in numerical form and as descriptive statements) about trends in flow-normalized concentration and flow-normalized load. Likelihood designations are computed from the two-sided attained p-value and follow the pattern described in Hirsch and others (2015) where a range of likelihood values from 0.95 to 1.0 is considered "highly likely," 0.90 to $<0.95$ is "very likely," 0.67 to $<0.90$ is "likely," and 0.50 to $<0.67$ is "uncertain." All input and output data associated with the WRTDS trend analysis are included in the data release (Day, 2021).

\section{Stagecoach Reservoir}

This report compares water temperature and selected water-quality data collected by the USGS during WYs 1989-93 and 2012-18 at two main-stem sites bracketing Stagecoach Reservoir: (1) Yampa River above Stagecoach Reservoir, CO (USGS site number 09237450), herein referred to as "Yampa River above Stagecoach Reservoir"; and (2) Yampa River below Stagecoach Reservoir, CO (USGS site number 09237500), herein referred to as "Yampa River below Stagecoach Reservoir." Data from WYs 1989 to 1993 were collected during reservoir construction and filling and are described in detail in Tobin (1996). Data from WYs 2012 to 18 were collected as part of routine water-quality sampling by the USGS. These data were reviewed to ensure comparisons between older and more recent data were valid and the data 
are comparable, in consideration of differences in detection limits and sample size. Permutation tests of independence (Helsel and others, 2020) were used to determine if there were differences in concentrations and loads of suspended sediment, Kjeldahl nitrogen, and total phosphorus between the two time periods at each site using a significance level $(\alpha)$ of 0.05 .

\section{Changes in Land Use}

Data from the National Land Cover Database (Multi-Resolution Land Characteristics Consortium, 2020) were used to (1) characterize land cover in 2016 for each landcover class and (2) assess changes in land cover from 2001 to 2016 for the forest and development land-cover classes. Zonal statistics in ArcGIS Desktop (Esri, 2018) were used to calculate the proportion of each land-cover class at basin (that is, in the UYRB) and subbasin scales for each year National Land Cover Database data were compiled, including 2001, 2004, 2006, 2008, 2011, 2013, and 2016. Changes in land cover were calculated as the cumulative change in land-cover class from 2001 to 2016.

\section{Assessment of Streamflow and Water Quality}

Streamflow and surface-water quality are affected by basin characteristics, including geological features, land cover, and climate. The combined effects of changes in land use, land management, and climate, including but not limited to changes in agricultural management practices, urbanization, and precipitation and temperature, can complicate tracking and assessing changes in hydrology, including streamflow and water quality. The following sections discuss data gaps and limitations that may inhibit the analysis from conveying specific interpretations.

\section{Streamflow Trends}

Changes in precipitation and temperature, land cover and land use, and water management can influence different aspects of streamflow, including low, moderate, and high streamflow-frequency distributions. Examining trends across different streamflow conditions and seasons can provide insight into which natural- and anthropogenic-related factors may influence these trends; this knowledge can help inform water management decisions. Comparing trends among sites with different levels of influence from agricultural-, urban-, and dam-related factors can also improve understanding of which factors may be causing streamflow changes in the basin. Likewise, examining trends across different time periods can help clarify the contribution of shorter-term changes from more persistent hydroclimatic changes, including changes in precipitation and temperature. Trends in daily streamflow statistics for monthly and annual time frames of 1-day maximum, mean, and 7-day minimum streamflows are presented graphically for eight sites from CYs 1992-2018 in figures 4 and 5. Streamflow trends at Yampa River at Steamboat Springs are also presented from a longer time period, for CYs 1910-2018, and a trend in deviation from peak streamflow is assessed for WYs 1910-2018 and displayed graphically, in figures 5 and 6.

Trends in streamflow at main-stem Yampa River sites from CY 1992, when the Stagecoach Reservoir was completed, through WY 2018 indicate some regionally consistent patterns (fig. 4). All main-stem sites had significant downward trends in one or more streamflow statistics during winter months. Downward trends were found across most months at Yampa River above Stagecoach Reservoir, with significant downward trends in January or February in mean and 7-day minimum streamflow statistics. Annual downward trends in 7-day minimum streamflows of 15 percent per decade, or 35 percent over the 27 -year period of analysis, were also observed (fig. 4A). These trends may be influenced by changes in reservoir management at one of three reservoirs upstream from this site (fig. 1), changes in water use, or climate-related changes in the basin. It is likely that the downward trends in streamflow at Yampa River above Stagecoach Reservoir and subsequent changes in reservoir management, including dam-related storage of winter and spring runoff and augmentation of summer water supplies, contribute to downward trends seen at sites below Stagecoach Reservoir, including Yampa River below Stagecoach, Yampa River at Steamboat Springs, Yampa River above Elkhead Creek, and Yampa River below Craig. At the site directly downstream from Stagecoach Reservoir, Yampa River below Stagecoach Reservoir, downward trends in all three streamflow statistics were found from September through February, ranging from 11 to 23 percent per decade, or 27 to 51 percent overall (fig. 4B). Downward trends in streamflow at Yampa River at Steamboat Springs, Yampa River above Elkhead Creek, and Yampa River below Craig had similar magnitudes over the same time period (fig. $4 C-E$ ). All main-stem sites had downward trends in July which extended through August at some sites (fig. 4). Although these trends are not significant based on 90-percent confidence intervals, they indicate that, if the same conditions continue, downward trends during these months may become more likely in the future.

Figure 4 (following page). Graphs showing changes in 1-day maximum, mean, and 7-day minimum streamflow statistics at five main-stem Yampa River sites in the Upper Yampa River Basin from climate years 1992 to 2018. A, Yampa River above Stagecoach Reservoir, Colorado (CO). B, Yampa River below Stagecoach Reservoir, CO. C, Yampa River at Steamboat Springs, CO. D, Yampa River above Elkhead Creek near Hayden, CO. E, Yampa River below Craig, CO. 

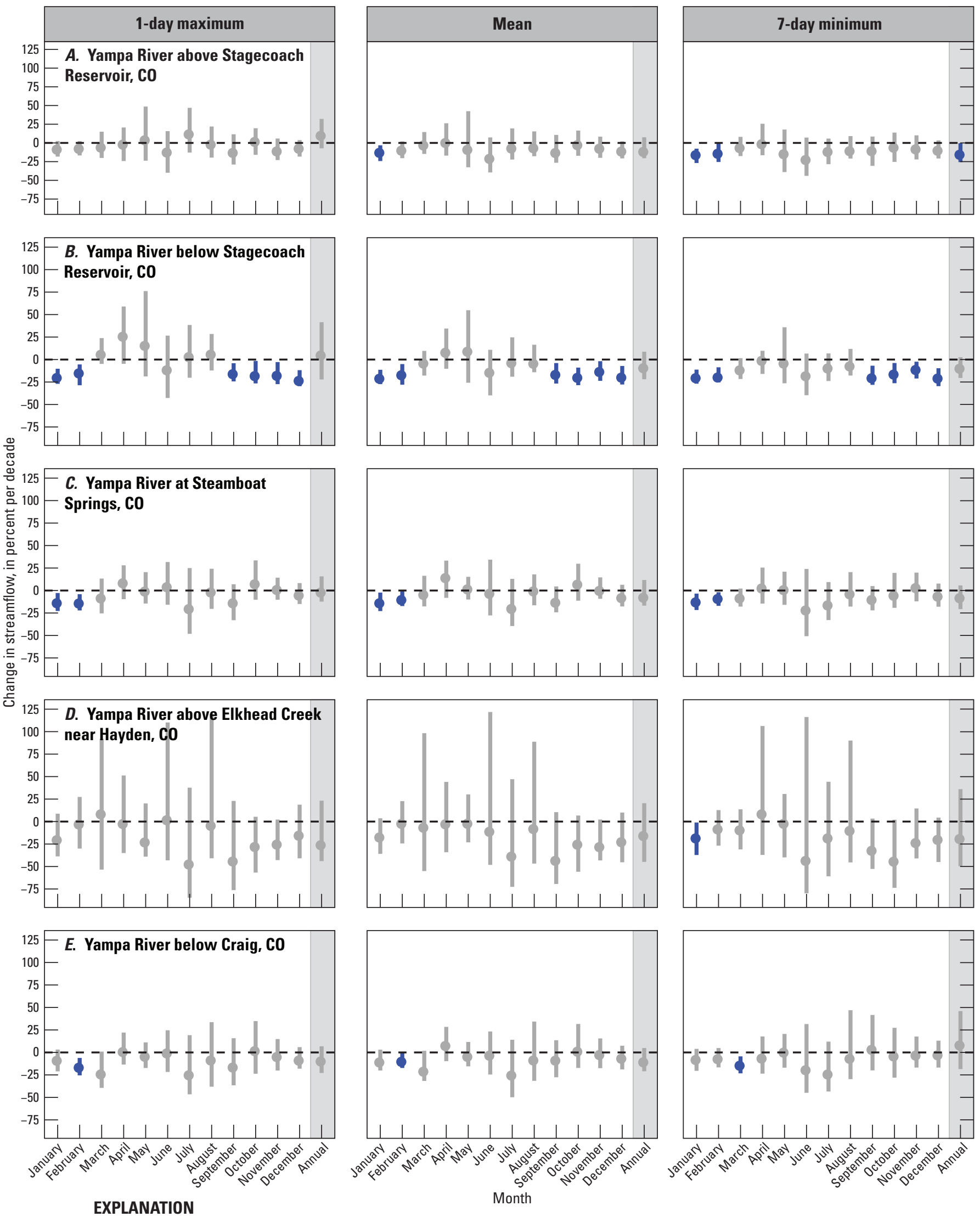

- Estimated slope

- Significant downward trend

90 percent confidence interval
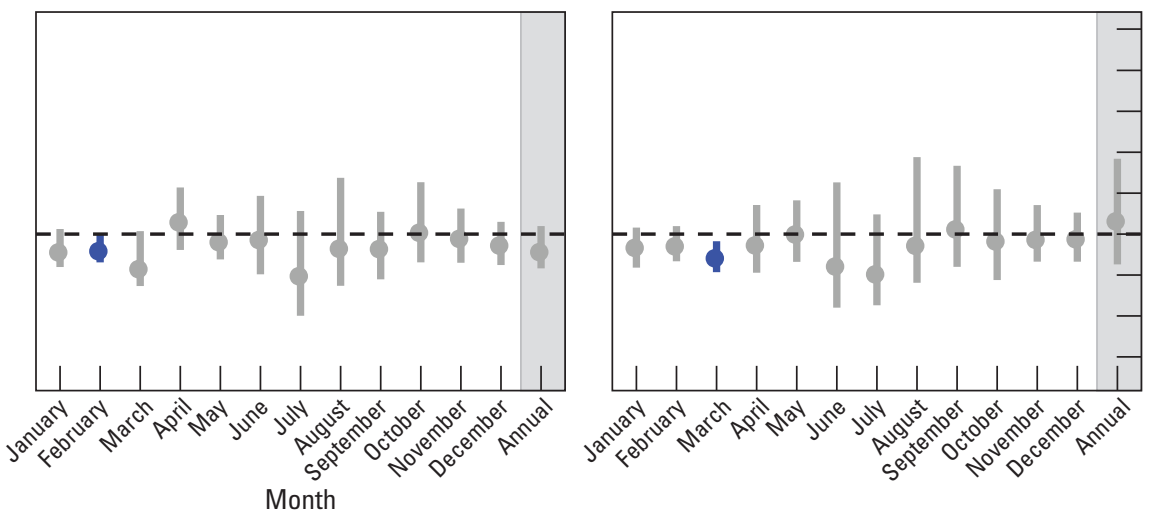

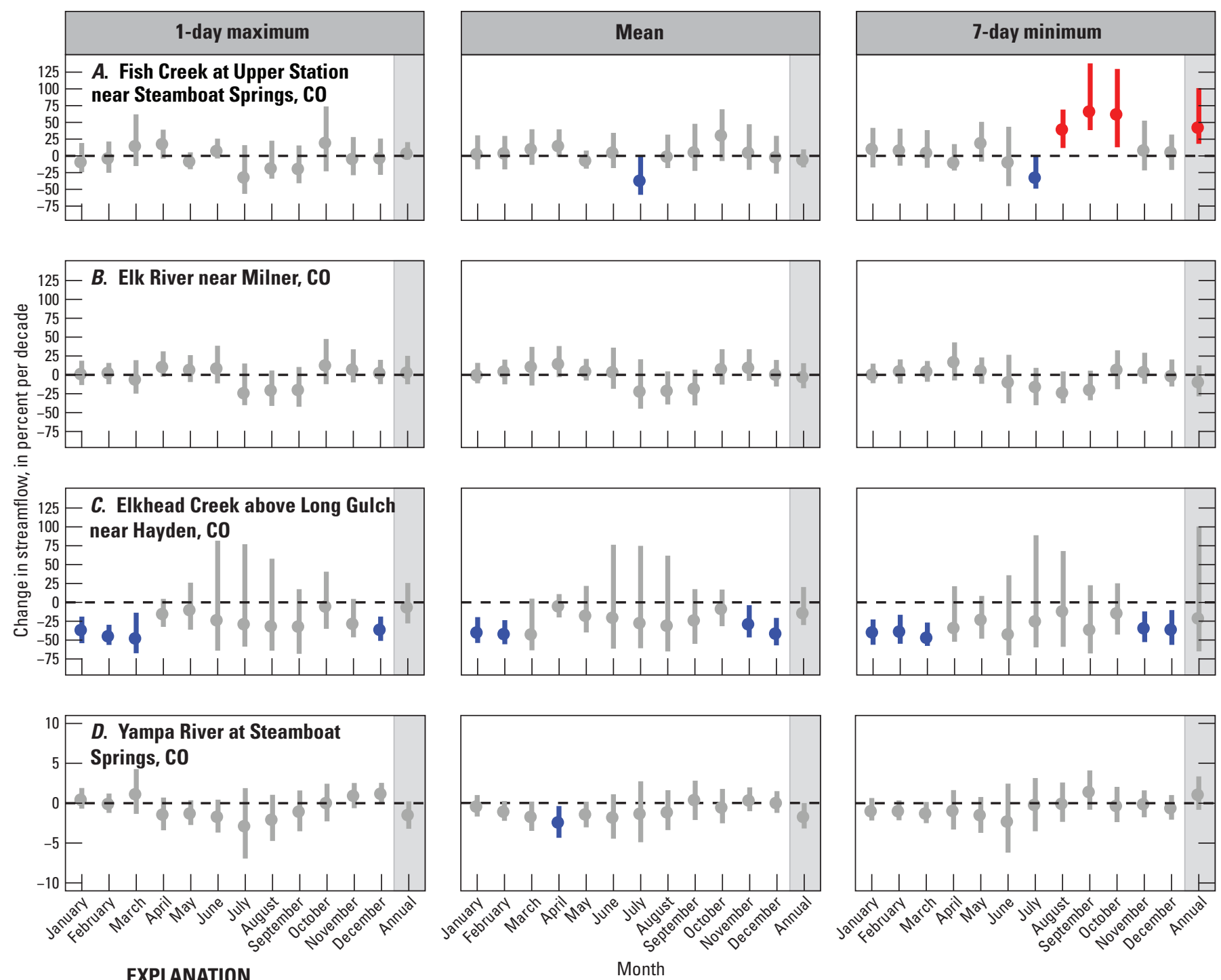

\section{EXPLANATION}

- Estimated slope

- Significant downward trend

- Significant upward trend

| 90 percent confidence interval

Figure 5. Graphs showing changes in 1-day maximum, mean, and 7-day minimum streamflow statistics for various time periods at 3 tributary sites in the Upper Yampa River Basin and 1 Yampa River main-stem site. A, Tributary site Fish Creek at Upper Station near Steamboat Springs, Colorado (CO) (climate years [CYs] 1992-2018). B, Tributary site Elk River near Milner, CO (CYs 1992-2018). C, Tributary site Elkhead Creek above Long Gulch near Hayden, CO (CYs 1996-2018). D, Yampa River main-stem site Yampa River at Steamboat Springs, CO (CYs 1910-2018). 


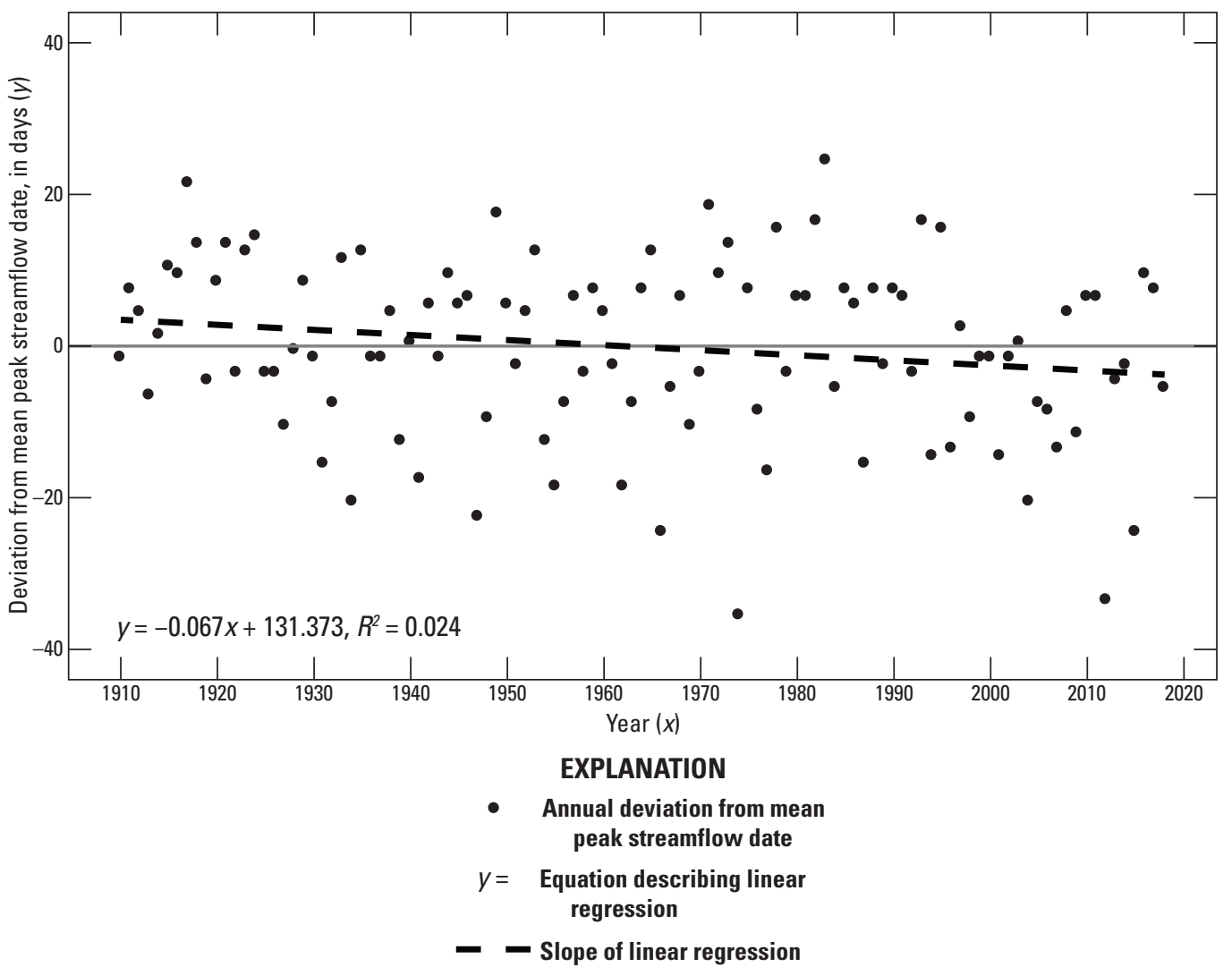

Figure 6. Graph showing the temporal deviation from the mean peak streamflow date at Yampa River at Steamboat Springs, Colo., for water years 1910-2018.

Trends in streamflow at tributary sites with upstream flow impoundments likely correspond to changes in reservoir management, but trends at sites with no upstream flow impoundments likely correspond to irrigation diversions and climate change related factors. At Fish Creek at Upper Station near Steamboat Springs, downward trends in mean and 7-day minimum streamflows of 36 percent and 31 percent per decade or 70 percent and 64 percent overall, were found in July, respectively. Significant upward trends in 7-day minimum streamflows ranging from 41 to 67 percent per decade, or 150 to 302 percent overall, occurred in August, September, and October from CY 1992 to CY 2018 (fig. 5A). These trends likely correspond to changes in water use at Fish Creek Reservoir, the primary source of municipal water for the city of Steamboat Springs. Releases from Fish Creek Reservoir usually start in late July (F. Alfone, Mt. Werner Water and Sanitation District, oral commun., 2020).

Though not significant based on 90-percent confidence intervals, downward trends in streamflow were found in summer months at Elk River near Milner (fig. $5 B$ ), which may become more likely if the conditions influencing streamflow persist. Like the main-stem sites, Elkhead Creek near Hayden also had significant downward trends in all three streamflow statistics during winter months, November through February, ranging from 27 to 44 percent per decade, or 58 to 79 percent overall (fig. 5C). Elkhead Creek near Hayden is upstream from Elkhead Reservoir (fig. 1), thus trends at this site may be more indicative of changes in climate factors or changes in water management, including diversion for irrigation.

Streamflow trends examined across a longer time period, from CY 1910 to CY 2018, at Yampa River at Steamboat Springs correspond to observed changes in streamflow documented across western North America and the Colorado River Basin (Miller and Piechota, 2008; Clow, 2010; Bennett and others, 2015). Downward trends were found during spring and summer months and annually for maximum and mean streamflows (fig. 5D). Significant downward trends in mean daily streamflows of 2 percent per decade, or 22 percent across the 109-year period of analysis, were found in April. A fairly significant ( $\mathrm{p}$-value $=0.06$ ) downward trend in the deviation from mean peak streamflow date was found, indicating that the date of peak streamflow is occurring earlier at Yampa River at Steamboat Springs (fig. 6). The significant downward trends in winter streamflows since the completion of Stagecoach Reservoir were not found across the longer time period of analysis (fig. $5 D$ ), supporting the hypothesis that reservoir 
management and shorter term climate-related factors likely play a role in decreasing streamflows during winter months. Downward trends in annual streamflows and a shift toward earlier season snowmelt runoff across western North America and the Colorado River Basin are predominately attributed to decreases in snowmelt runoff, which accounts for a large proportion of the annual water budget (Miller and Piechota, 2008; Clow, 2010; Bennett and others, 2015).

\section{Concentration Estimates and Comparisons to Interim Concentrations for Water-Quality Standards}

This section summarizes concentrations of suspended sediment, Kjeldahl nitrogen, total nitrogen, total phosphorus, and orthophosphate at selected sites in the UYRB. Suspended sediments are particles suspended in water that range in size from sand to clay and are derived from instream sources, such as the breakdown of terrestrial and aquatic biota, and from external sources, such as storm and urban runoff and wastes from industry and water treatment plants (Kenney and others, 2009). High concentrations of suspended sediment interfere with water-treatment processes and recreational use of streams (Lorenz and others, 2009). Nutrients, such as Kjeldahl nitrogen, total nitrogen, total phosphorus, and orthophosphate, naturally occur in water as a result of weathering and erosion of rocks and soils, breakdown of organic material, and atmospheric deposition; these nutrients also result from human-related activities, including application of fertilizers, runoff from agricultural and urban areas, wastewater treatment and septic tank effluent, use of detergents, animal waste runoff, and combustion of fuels. High nutrient concentrations in surface water can cause excessive growth of algae and other nuisance aquatic plants, which can cause a wide range of problems including a reduction in dissolved oxygen levels, decrease in habitat quality, decrease in water clarity, and enhancement of the growth of toxic algae (Lopez and others, 2008).

In addition to concentrations of suspended sediment, Kjeldahl nitrogen, total nitrogen, total phosphorus, and orthophosphate, this section discusses regression model coefficients and the overall fit of models for suspended sediment, Kjeldahl nitrogen, and total phosphorus concentrations. For 2 sites, constituent concentrations were analyzed for WYs 1999-2018, and for 5 sites, constituent concentrations were analyzed for WYs 2010-18 (table 1). Estimated annual median concentrations of these constituents were summarized for WYs 2010-18 for all sites and are discussed and shown in tabular form. Monthly boxplots of discrete and estimated daily concentrations of suspended sediment, Kjeldahl nitrogen, and total phosphorus are discussed and shown graphically. Discrete concentrations are also given for Little Morrison Creek near Stagecoach, CO (USGS site number 401634106502200), herein referred to as "Little Morrison Creek," a minor inflow on the southern edge of Stagecoach Reservoir (fig. 1) for water-quality data collected in WYs 2012-14 and 2017-18 (table 1). Discrete and estimated concentrations of Kjeldahl nitrogen, total nitrogen, total phosphorus, and orthophosphate are compared to CDPHE interim water-quality standards for total nitrogen and total phosphorus concentrations.

\section{Regression Equation Variable Coefficients and Statistical Diagnostics}

Tables 3 and 4 provide regression model coefficients and statistical diagnostics from models used to predict concentrations and loads of suspended sediment at 5 sites, and Kjeldahl nitrogen and total phosphorus at 7 sites in the Upper Yampa River Basin. The regression models were developed through the R-LOADEST program (Lorenz and others, 2015), which is an R-based version of the USGS statistical program LOAD ESTimator (LOADEST; Runkel and others, 2004). Table 3 provides regression model coefficients and statistical diagnostics for concentrations. Table 4 provides regression model coefficients and statistical diagnostics for loads.

\section{Suspended Sediment}

Regression models for suspended sediment concentrations were created at five sites (table 3 ). All adjusted $R^{2}$ values for suspended sediment were $>0.7$ except at Yampa River above Stagecoach Reservoir, which had an adjusted $R^{2}$ value of 0.17 (table 3). There was no suspended sediment data for the time periods analyzed in this report for the sites Yampa River below Craig and Yampa River at Steamboat Springs.

The highest estimated median annual concentration of suspended sediment for WYs 2010-18 (table 5) occurred at Yampa River above Stagecoach Reservoir $(14 \mathrm{mg} / \mathrm{L})$ and was almost twice that of the next highest concentration (7.4 $\mathrm{mg} / \mathrm{L}$ ) at Yampa River above Elkhead Creek near Hayden, CO (USGS site number 09244490), herein referred to as "Yampa River above Elkhead Creek." Given the relatively poor model fit at Yampa River above Stagecoach Reservoir, a comparison of median annual concentrations of discrete values was used to validate model results. The median annual concentration of discrete values at each site, for WYs 2010-18, generally agreed with estimated median annual results and was highest at Yampa River above Stagecoach Reservoir $(8.0 \mathrm{mg} / \mathrm{L})$; the next highest discrete concentration was at Yampa River below Oak Creek ( $4.5 \mathrm{mg} / \mathrm{L})$. Generally, the estimated concentrations were highest during spring runoff events (fig. 7). 
Table 3. Regression model coefficients and statistical diagnostics for concentrations of suspended sediment at 5 sites, and Kjeldahl nitrogen and total phosphorus at 7 sites in the Upper Yampa River Basin, Colorado (CO).

[USGS, U.S. Geological Survey; $\ln$, natural logarithm; Q-Q*, centered daily streamflow in cubic feet per second (ft $\left.{ }^{3} / \mathrm{s}\right)$; t- $\mathrm{t}^{*}$, centered decimal time in decimal years; sin( $2 \pi \mathrm{T}$ ), sine function of a Fourier Series; $\pi$, approximately 3.14159; T, decimal portion of the year starting January $1 ; \cos (2 \pi \mathrm{T})$, cosine function of a Fourier Series; $k$, an integer; ERV, estimated residual variance; Adjusted $R^{2}$, adjusted coefficient of determination; SCR, serial correlation of the residuals; Est., estimate coefficient; p-value, significance statistic; $<$, less than; - , coefficient not included in the model]

\begin{tabular}{|c|c|c|c|c|c|c|c|c|c|c|c|c|c|c|c|c|c|}
\hline \multirow[t]{2}{*}{ USGS site name } & \multicolumn{2}{|c|}{$\begin{array}{c}\text { Y-axis } \\
\text { intercept }\end{array}$} & \multicolumn{2}{|c|}{$\ln \left(0-Q^{*}\right)$} & \multicolumn{2}{|c|}{$t-t^{*}$} & \multicolumn{2}{|c|}{$\underset{k=1}{\sin \left(k^{*} 2 \pi T\right)}$} & \multicolumn{2}{|c|}{$\underset{k=1}{\cos \left(k^{*} 2 \pi T\right)}$} & \multicolumn{2}{|c|}{$\underset{k=2}{\sin \left(k^{*} 2 \pi T\right)}$} & \multicolumn{2}{|c|}{$\begin{array}{c}\cos \left(k^{*} 2 \pi T\right) \\
k=2\end{array}$} & \multirow[t]{2}{*}{ ERV } & \multirow{2}{*}{$\begin{array}{c}\text { Adjusted } \\
R^{2}\end{array}$} & \multirow{2}{*}{ SCR } \\
\hline & Est. & p-value & Est. & p-value & Est. & p-value & Est. & p-value & Est. & p-value & Est. & p-value & Est. & p-value & & & \\
\hline \multicolumn{18}{|c|}{ Suspended sediment, in milligrams per liter } \\
\hline $\begin{array}{l}\text { Yampa River above Stagecoach } \\
\text { Reservoir, CO }\end{array}$ & 2.3 & $<0.001$ & 0.77 & 0.01 & - & - & - & - & - & - & - & - & - & - & 1.19 & 0.17 & 0.28 \\
\hline $\begin{array}{c}\text { Yampa River below Oak Creek } \\
\text { near Steamboat Springs, CO }\end{array}$ & 1.7 & $<0.001$ & -0.05 & 0.77 & - & - & 0.92 & $<0.001$ & -0.45 & 0.02 & -0.52 & 0.01 & -0.28 & 0.04 & 0.33 & 0.71 & 0.07 \\
\hline Elk River near Milner, CO & 2.0 & $<0.001$ & 0.69 & $<0.001$ & - & - & 0.56 & 0.01 & 0.32 & 0.13 & - & - & - & - & 0.44 & 0.77 & -0.09 \\
\hline Yampa River at Milner, CO & 1.9 & $<0.001$ & 0.44 & 0.07 & - & - & 0.78 & 0.00 & -0.26 & 0.33 & -0.21 & 0.38 & -0.44 & 0.01 & 0.48 & 0.75 & -0.27 \\
\hline $\begin{array}{l}\text { Yampa River above Elkhead Creek } \\
\text { near Hayden, CO }\end{array}$ & 2.6 & $<0.001$ & 0.99 & $<0.001$ & - & - & - & - & - & - & - & - & - & - & 0.57 & 0.76 & -0.14 \\
\hline \multicolumn{18}{|c|}{ Kjeldahl nitrogen, in milligrams per liter } \\
\hline $\begin{array}{l}\text { Yampa River above Stagecoach } \\
\text { Reservoir, CO }\end{array}$ & -1.0 & $<0.001$ & 0.16 & 0.01 & - & - & 0.20 & 0.00 & -0.49 & $<0.001$ & -0.04 & 0.37 & 0.09 & 0.05 & 0.03 & 0.88 & -0.03 \\
\hline $\begin{array}{c}\text { Yampa River below Oak Creek } \\
\text { near Steamboat Springs, CO }\end{array}$ & -0.96 & $<0.001$ & -0.19 & 0.03 & - & - & 0.08 & 0.33 & -0.17 & 0.05 & -0.11 & 0.20 & -0.20 & $<0.001$ & 0.08 & 0.31 & -0.26 \\
\hline $\begin{array}{l}\text { Yampa River at Steamboat } \\
\text { Springs, CO }\end{array}$ & -1.1 & $<0.001$ & -0.11 & 0.01 & - & - & 0.05 & 0.24 & -0.09 & 0.07 & -0.02 & 0.72 & -0.11 & $<0.001$ & 0.05 & 0.26 & 0.03 \\
\hline Elk River near Milner, $\mathrm{CO}$ & -1.6 & $<0.001$ & $<0.001$ & 0.99 & - & - & 0.26 & 0.04 & -0.30 & 0.03 & -0.15 & 0.23 & -0.32 & $<0.001$ & 0.09 & 0.62 & -0.05 \\
\hline Yampa River at Milner, CO & -1.2 & $<0.001$ & 0.17 & 0.03 & - & - & 0.02 & $<0.001$ & -0.20 & 0.03 & -0.10 & 0.20 & -0.24 & $<0.001$ & 0.05 & 0.51 & 0.04 \\
\hline $\begin{array}{l}\text { Yampa River above Elkhead Creek } \\
\text { near Hayden, CO }\end{array}$ & -0.94 & $<0.001$ & 0.12 & 0.01 & - & - & - & - & - & - & - & - & - & - & 0.14 & 0.16 & -0.13 \\
\hline Yampa River below Craig, CO & -1.0 & $<0.001$ & -0.03 & 0.56 & - & - & 0.27 & $<0.001$ & -0.24 & $<0.001$ & 0.01 & 0.85 & -0.26 & $<0.001$ & 0.06 & 0.57 & -0.30 \\
\hline \multicolumn{18}{|c|}{ Total phosphorus, in milligrams per liter } \\
\hline $\begin{array}{l}\text { Yampa River above Stagecoach } \\
\text { Reservoir, CO }\end{array}$ & -2.8 & $<0.001$ & 0.37 & $<0.001$ & - & - & 0.22 & $<0.001$ & -0.42 & $<0.001$ & - & - & - & - & 0.08 & 0.79 & 0.03 \\
\hline $\begin{array}{c}\text { Yampa River below Oak Creek } \\
\text { near Steamboat Springs, CO }\end{array}$ & -3.0 & $<0.001$ & -0.25 & 0.03 & - & - & 0.4 & 0.01 & -0.29 & 0.01 & -0.13 & 0.22 & -0.22 & 0.01 & 0.12 & 0.39 & -0.04 \\
\hline $\begin{array}{l}\text { Yampa River at Steamboat } \\
\text { Springs, CO }\end{array}$ & -3.2 & $<0.001$ & -0.08 & 0.26 & - & - & 0.16 & 0.04 & -0.21 & 0.02 & 0.12 & 0.15 & -0.19 & $<0.001$ & 0.15 & 0.27 & 0.04 \\
\hline Elk River near Milner, CO & -3.9 & $<0.001$ & 0.06 & 0.7 & - & - & 0.66 & $<0.001$ & -0.47 & 0.02 & -0.26 & 0.14 & -0.37 & $<0.001$ & 0.21 & 0.75 & -0.21 \\
\hline Yampa River at Milner, CO & -3.1 & $<0.001$ & -0.29 & $<0.001$ & - & - & 0.51 & $<0.001$ & -0.12 & 0.33 & - & - & - & - & 0.15 & 0.40 & -0.33 \\
\hline $\begin{array}{l}\text { Yampa River above Elkhead } \\
\text { Creek near Hayden, CO }\end{array}$ & -2.9 & $<0.001$ & 0.21 & 0.03 & - & - & 0.48 & $<0.001$ & 0.01 & 0.94 & - & - & - & - & 0.25 & 0.59 & -0.33 \\
\hline Yampa River below Craig, CO & -3.0 & $<0.001$ & 0.12 & 0.11 & - & - & 0.53 & $<0.001$ & -0.27 & 0 & -0.03 & 0.77 & -0.29 & $<0.001$ & 0.16 & 0.67 & -0.16 \\
\hline
\end{tabular}


Table 4. Regression model coefficients and statistical diagnostics for loads of suspended sediment at 5 sites, and Kjeldahl nitrogen and total phosphorus at 7 sites, in the Upper Yampa River Basin, Colorado (CO).

[USGS, U.S. Geological Survey; ln, natural logarithm; Q-Q*, centered daily streamflow in cubic feet per second ( $\left.\mathrm{ft}^{3} / \mathrm{s}\right)$; t-t*, centered decimal time in decimal years; sin( $\left.2 \pi \mathrm{T}\right)$, sine function of a Fourier Series; $\pi$, approximately $3.14159 ; \mathrm{T}$, decimal portion of the year starting January $1 ; \cos (2 \pi \mathrm{T})$, cosine function of a Fourier Series; $k$, is an integer; ERV, estimated residual variance; $R^{2}$, adjusted coefficient of determination; SCR, serial correlation of the residuals; Est., estimate coefficient; p-value, significance statistic; <, less than; -, coefficient not included in the model]

\begin{tabular}{|c|c|c|c|c|c|c|c|c|c|c|c|c|c|c|c|c|c|}
\hline \multirow{2}{*}{ USGS site name } & \multicolumn{2}{|c|}{$\begin{array}{c}\text { Y-axis } \\
\text { intercept }\end{array}$} & \multicolumn{2}{|c|}{$\ln \left(\mathbf{Q}-\mathbf{Q}^{*}\right)$} & \multicolumn{2}{|c|}{$t-t^{*}$} & \multicolumn{2}{|c|}{$\begin{array}{c}\sin \left(k^{*} 2 \pi T\right) \\
k=1\end{array}$} & \multicolumn{2}{|c|}{$\begin{array}{c}\cos \left(k^{*} 2 \pi T\right) \\
k=1\end{array}$} & \multicolumn{2}{|c|}{$\begin{array}{c}\sin \left(k^{*} 2 \pi T\right) \\
k=2\end{array}$} & \multicolumn{2}{|c|}{$\begin{array}{c}\cos \left(k^{*} 2 \pi T\right) \\
k=2\end{array}$} & \multirow{2}{*}{ ERV } & \multirow{2}{*}{$\begin{array}{l}\text { Adjusted } \\
R^{2}\end{array}$} & \multirow{2}{*}{ SCR } \\
\hline & Est. & p-value & Est. & p-value & Est. & p-value & Est. & p-value & Est. & p-value & Est. & p-value & Est. & p-value & & & \\
\hline \multicolumn{18}{|c|}{ Suspended sediment, in milligrams per liter } \\
\hline $\begin{array}{l}\text { Yampa River above Stagecoach } \\
\text { Reservoir, CO }\end{array}$ & 7.5 & $<0.001$ & 1.77 & $<0.001$ & - & - & - & - & - & - & - & - & - & - & 1.19 & 0.51 & 0.28 \\
\hline $\begin{array}{l}\text { Yampa River below Oak Creek near } \\
\text { Steamboat Springs, CO }\end{array}$ & 8.2 & $<0.001$ & 0.95 & $<0.001$ & - & - & 0.92 & $<0.001$ & -0.45 & 0.02 & -0.52 & 0.01 & -0.28 & 0.04 & 0.33 & 0.92 & 0.07 \\
\hline Elk River near Milner, CO & 8.9 & $<0.001$ & 1.69 & $<0.001$ & - & - & 0.56 & 0.01 & 0.32 & 0.13 & - & - & - & - & 0.44 & 0.94 & -0.09 \\
\hline Yampa River at Milner, CO & 9.6 & $<0.001$ & 0.44 & $<0.001$ & - & - & 0.78 & $<0.001$ & -0.26 & 0.33 & -0.28 & 0.38 & -0.44 & 0.01 & 0.48 & 0.92 & -0.27 \\
\hline $\begin{array}{l}\text { Yampa River above Elkhead Creek } \\
\text { near Hayden, CO }\end{array}$ & 10 & $<0.001$ & 1.99 & $<0.001$ & - & - & - & - & - & - & - & - & - & - & 0.57 & 0.93 & -0.14 \\
\hline \multicolumn{18}{|c|}{ Kjeldahl nitrogen, in milligrams per liter } \\
\hline $\begin{array}{l}\text { Yampa River above Stagecoach } \\
\text { Reservoir, CO }\end{array}$ & 4.2 & $<0.001$ & 1.16 & $<0.001$ & - & - & 0.20 & $<0.001$ & -0.49 & $<0.001$ & -0.04 & 0.37 & 0.09 & 0.05 & 0.03 & 0.97 & -0.03 \\
\hline $\begin{array}{l}\text { Yampa River below Oak Creek near } \\
\text { Steamboat Springs, CO }\end{array}$ & 5.6 & $<0.001$ & 0.81 & $<0.001$ & - & - & 0.08 & 0.33 & -0.17 & 0.05 & -0.11 & 0.20 & -0.20 & $<0.001$ & 0.08 & 0.93 & -0.26 \\
\hline Yampa River at Steamboat Springs, CO & 5.8 & $<0.001$ & 0.89 & $<0.001$ & - & - & 0.05 & 0.24 & -0.09 & 0.07 & -0.02 & 0.72 & -0.11 & $<0.001$ & 0.05 & 0.96 & 0.03 \\
\hline Elk River near Milner, $\mathrm{CO}$ & 5.2 & $<0.001$ & 1.00 & $<0.001$ & - & - & 0.27 & 0.04 & -0.30 & 0.03 & -0.15 & 0.23 & -0.32 & $<0.001$ & 0.09 & 0.97 & -0.05 \\
\hline Yampa River at Milner, CO & 6.5 & $<0.001$ & 0.83 & $<0.001$ & - & - & 0.24 & $<0.001$ & -0.20 & 0.03 & -0.10 & 0.20 & -0.24 & $<0.001$ & 0.05 & 0.97 & 0.04 \\
\hline $\begin{array}{l}\text { Yampa River above Elkhead Creek } \\
\text { near Hayden, CO }\end{array}$ & 6.6 & $<0.001$ & 1.12 & $<0.001$ & - & - & - & - & - & - & - & - & - & - & 0.14 & 0.94 & -0.13 \\
\hline Yampa River below Craig, CO & 6.6 & $<0.001$ & 0.97 & $<0.001$ & - & - & 0.27 & $<0.001$ & -0.24 & $<0.001$ & 0.01 & 0.85 & -0.26 & $<0.001$ & 0.06 & 0.97 & -0.30 \\
\hline \multicolumn{18}{|c|}{ Total phosphorus, in milligrams per liter } \\
\hline $\begin{array}{l}\text { Yampa River above Stagecoach } \\
\text { Reservoir, CO }\end{array}$ & 2.4 & $<0.001$ & 1.37 & $<0.001$ & - & - & 0.22 & $<0.001$ & -0.42 & $<0.001$ & - & - & - & - & 0.08 & 0.95 & 0.03 \\
\hline $\begin{array}{l}\text { Yampa River below Oak Creek near } \\
\text { Steamboat Springs, CO }\end{array}$ & 3.6 & $<0.001$ & 0.75 & $<0.001$ & - & - & 0.40 & $<0.001$ & -0.29 & 0.01 & -0.13 & 0.22 & -0.22 & 0.01 & 0.12 & 0.92 & -0.04 \\
\hline Yampa River at Steamboat Springs, CO & 3.7 & $<0.001$ & 0.92 & $<0.001$ & - & - & 0.16 & 0.04 & 0.02 & 0.02 & 0.12 & 0.15 & -0.19 & $<0.001$ & 0.15 & 0.90 & 0.04 \\
\hline Elk River near Milner, CO & 3.0 & $<0.001$ & 1.06 & $<0.001$ & - & - & 0.66 & $<0.001$ & -0.47 & 0.02 & -0.26 & 0.14 & -0.37 & $<0.001$ & 0.21 & 0.96 & -0.21 \\
\hline Yampa River at Milner, CO & 4.6 & $<0.001$ & 0.71 & $<0.001$ & - & - & 0.51 & $<0.001$ & -0.12 & 0.33 & - & - & - & - & 0.15 & 0.90 & -0.33 \\
\hline $\begin{array}{l}\text { Yampa River above Elkhead Creek } \\
\text { near Hayden, CO }\end{array}$ & 4.6 & $<0.001$ & 1.21 & $<0.001$ & - & - & 0.48 & $<0.001$ & 0.01 & 0.94 & - & - & - & - & 0.25 & 0.94 & -0.33 \\
\hline Yampa River below Craig, CO & 4.7 & $<0.001$ & 1.12 & $<0.001$ & - & - & 0.53 & $<0.001$ & -0.27 & $<0.001$ & -0.03 & 0.77 & -0.29 & $<0.001$ & 0.16 & 0.96 & -0.16 \\
\hline
\end{tabular}


Table 5. Estimated annual median and median annual concentrations of suspended sediment at 5 water-quality sites in the Upper Yampa River Basin, Colorado (CO), and Kjeldahl nitrogen and total phosphorus at 7 water-quality sites in the Upper Yampa River Basin for water years (WYs) 2010-18.

[A "WY" is defined as the 12-month period from October 1 through September 30 and designated by the year in which it ends. Estimated annual median concentrations were calculated using linear regression techniques. USGS, U.S. Geological Survey]

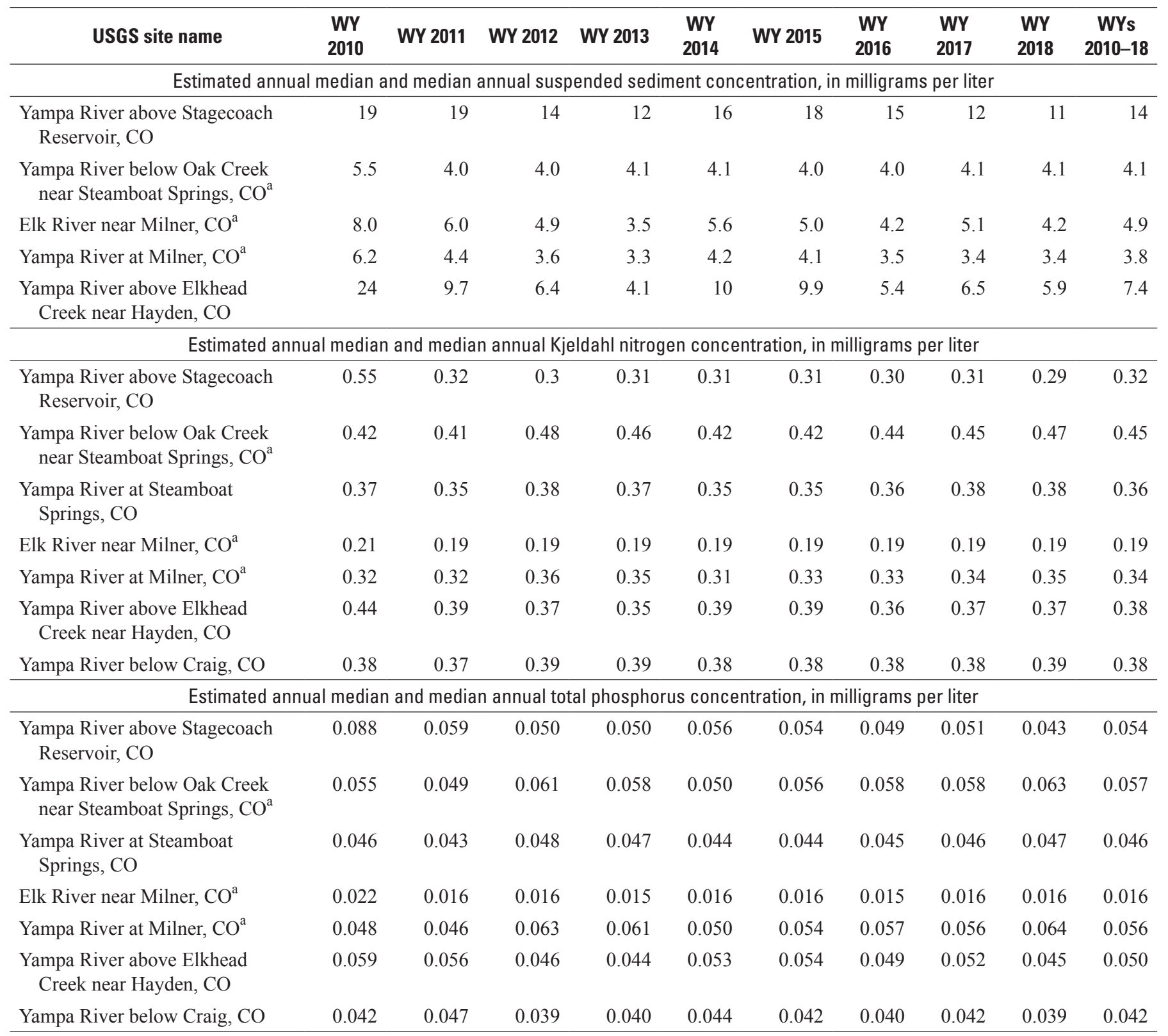

aEstimated hydrograph used in linear regression model. The limitations of estimated hydrographs are discussed in the "Extension of Streamflow Record" section. 


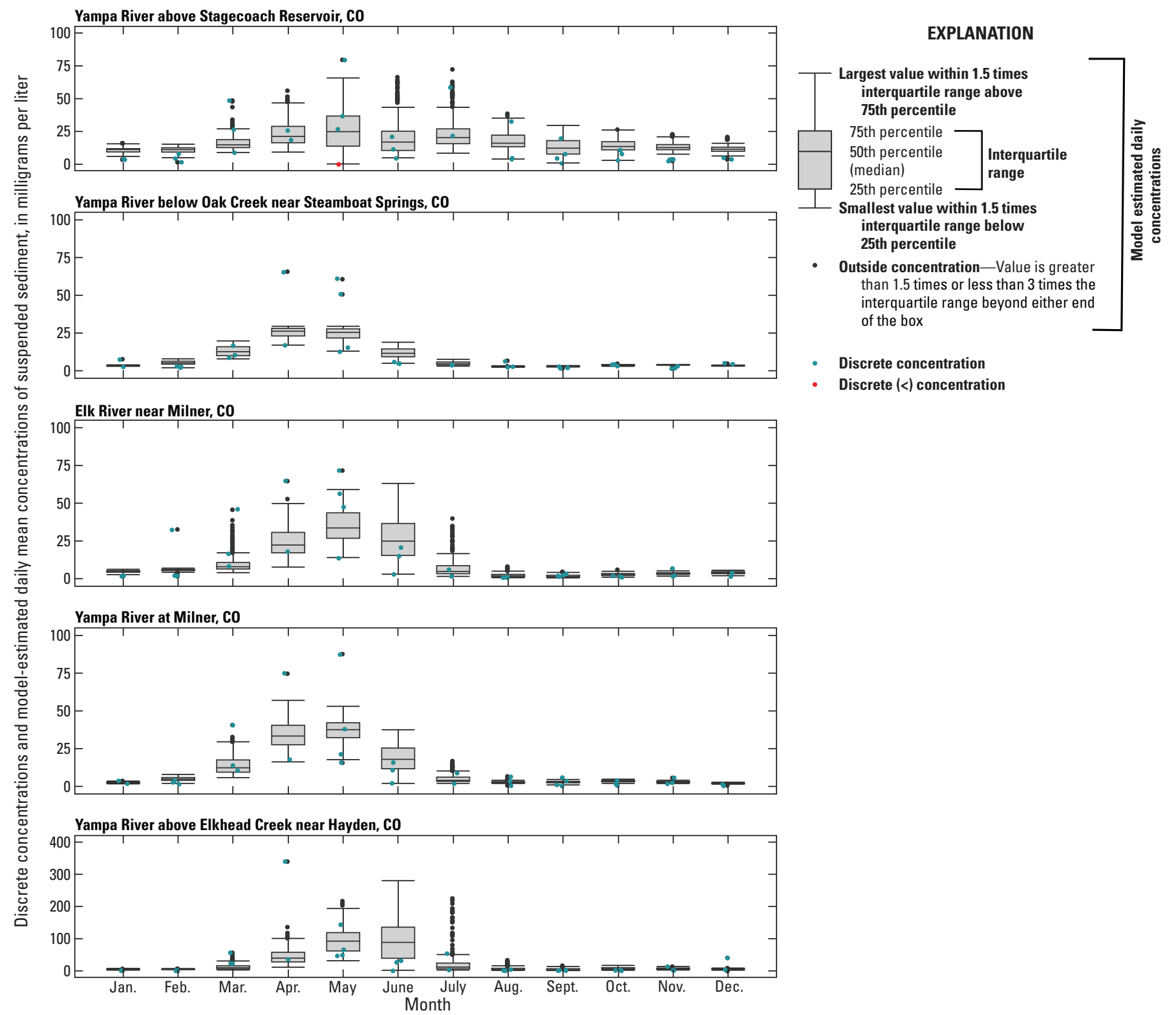

Figure 7. Discrete concentrations and boxplots of model-estimated daily mean concentrations of suspended sediment at five sites in the Upper Yampa River Basin, Colorado (CO), on a monthly basis for water years 2010-18. "Discrete concentration" refers to the uncensored discrete data. "Discrete $(<)$ concentration" refers to concentrations less than $(<)$ the method detection limit. 


\section{Nitrogen}

Nitrogen occurs in several chemical species or forms, including total nitrogen, nitrate, and ammonia. Total nitrogen includes nitrogen in its inorganic and organic forms. Organic forms of nitrogen are derived from plant material or organic contaminants and are generally unavailable to living organisms until they are converted to an inorganic form, including nitrite, nitrate, and ammonia. Nitrite typically is present in low concentrations in streams because it is unstable in oxygenated water, and high levels of nitrite generally indicate contamination from sewage or organic waste (Hem, 1985). Nitrate is more stable than nitrite in the presence of oxygen and is generally present in low concentrations in streams and lakes because it is readily consumed by aquatic plants. Ammonia occurs in water as ammonium $\left(\mathrm{NH}_{4}^{+}\right)$, the form used by living organisms, or as un-ionized ammonia $\left(\mathrm{NH}_{3}\right)$, the form that can be toxic to fish in excessive concentrations (Mueller and others, 1995). Kjeldahl nitrogen is a direct measure of ammonia plus organic nitrogen and is used as a surrogate for total nitrogen in the UYRB (see the "Data Compilation and Quality Assurance" section for more detail). Regression model coefficients and statistical diagnostics for Kjeldahl nitrogen concentrations are presented in table 3. Values of adjusted $R^{2}$ were $<0.5$ at 3 of the 7 stream sites: Yampa River below Oak Creek, Yampa River at Steamboat Springs, and Yampa River above Elkhead Creek (table 3). This indicates that additional variables are needed to improve predictions of variations in Kjeldahl nitrogen concentrations. It is also possible that changes in stream nutrient concentrations caused by rain or snowmelt events are not characterized by quarterly sampling. Also, point-source inputs of nitrogen that are not necessarily related to streamflow can affect the accuracy of the regression models.

The estimated median annual concentration of Kjeldahl nitrogen for WYs 2010-18 was highest at Yampa River below Oak Creek $(0.45 \mathrm{mg} / \mathrm{L})$ and lowest at Elk River near Milner $(0.19 \mathrm{mg} / \mathrm{L}$; table 5$)$. Estimated daily mean concentrations at Yampa River above Stagecoach Reservoir were highest during early summer (fig. 8). At most sites downstream from Stagecoach Reservoir, estimated daily mean concentrations tended to be highest during early spring and lowest during summer and winter months (fig. 8).

Kjeldahl nitrogen was also used as a surrogate for total nitrogen in comparisons to the CDPHE interim water-quality standard. Estimated annual median and median annual concentrations of Kjeldahl nitrogen at the seven sites for WYs 2010-18 were less than the interim standard for total nitrogen of $1.25 \mathrm{mg} / \mathrm{L}$ (table 5). Discrete Kjeldahl nitrogen concentrations exceeded the interim total nitrogen standard $(1.25 \mathrm{mg} / \mathrm{L})$ only three times, in WY 2010 at Yampa River above Elkhead Creek near Hayden, and in WYs 2002 and 2010 at Yampa River below Craig (fig. 8). Each exceedance occurred in April, the onset of early spring runoff events. Discrete concentrations of total nitrogen were also compared to the interim standard (fig. 9). Concentrations exceeded the interim standard on
5 sample days in WYs 1999, 2000, 2002, 2008, and 2010 at Yampa River below Craig, and on 1 sample day in WY 2010 at Yampa River above Elkhead Creek near Hayden. Each exceedance occurred during spring runoff or first flush events in March and April.

\section{Phosphorus}

Phosphorus occurs in several forms including total phosphorus and orthophosphate. Total phosphorus is typically bound to sediment and includes dissolved phosphates and particulate organic phosphorus. Orthophosphate is the dominant form of dissolved phosphorus in natural water and can be readily assimilated by plants. The presence of phosphorus in surface water can indicate that erosion and sediment transport are occurring (Mueller and others, 1995). In general, the adjusted $R^{2}$ values of total phosphorus models were higher than the $R^{2}$ values of Kjeldahl nitrogen models (table 3 ). However, 3 of 7 sites had adjusted $R^{2}$ values for total phosphorus of $<0.5$, including Yampa River below Oak Creek near Steamboat Springs, Yampa River at Steamboat Springs, and Yampa River at Milner (table 3). As with Kjeldahl nitrogen, additional surrogates could improve the ability to predict variations in concentrations of total phosphorus. Visual inspection of total phosphorus and suspended sediment concentrations indicate fairly strong relations between the two constituents at five sites (fig. 10), which indicates that including a continuous surrogate for suspended sediment, such as turbidity, might improve future total phosphorus models (Jones and others, 2011; Lessels and Bishop, 2013).

The estimated median annual concentration of total phosphorus for WYs 2010-18 was highest at Yampa River below Oak Creek $(0.057 \mathrm{mg} / \mathrm{L})$ and lowest at Elk River near Milner $(0.016 \mathrm{mg} / \mathrm{L})$ (table 5). The concentrations for Yampa River above Stagecoach Reservoir were highest during late spring and early summer (fig. 11). Most sites downstream from Stagecoach Reservoir had the highest estimated daily mean concentrations during early spring (fig. 11). Little seasonal variation was observed at Yampa River at Steamboat Springs. The regression model at this site explained only 27 percent of the variance in total phosphorus concentrations (table 3); thus, the model is limited in its ability to predict variation in concentrations, and additional surrogates are needed to strengthen the relation. The concentrations for Yampa River at Milner were highest during late winter and early spring (fig. 11).

Estimated annual median and median annual concentrations of total phosphorus at the seven sites for WYs 2010-18 were less than the CDPHE interim standard of 0.11 $\mathrm{mg} / \mathrm{L}$ (table 5). Discrete concentrations of total phosphorus exceeded the CDPHE interim standard at least twice at each site (fig. 11). Estimated daily mean concentrations exceeded the interim standard at each site during some spring and summer months (fig. 11). A limited amount of water-quality data and lack of a streamflow record prevented regression modeling of total phosphorus concentrations at Little Morrison 


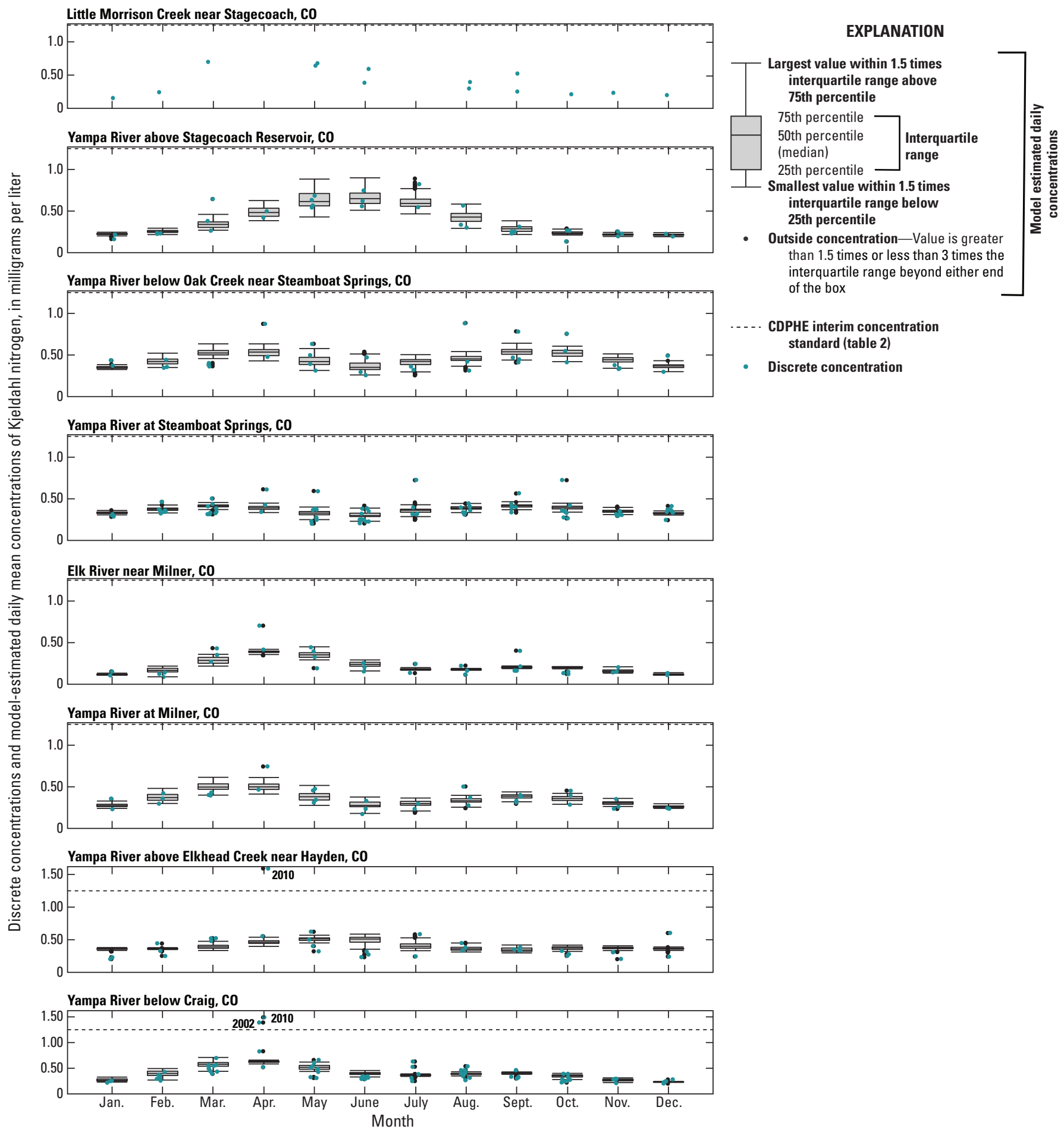

Figure 8. Discrete concentrations and boxplots of model-estimated daily mean concentrations of Kjeldahl nitrogen at eight sites in the Upper Yampa River Basin, Colorado (CO), for various starting water years through water year 2018. "Discrete concentration" refers to the uncensored discrete data. (CDPHE, Colorado Department of Public Health and Environment)

Figure 9. (following page) Discrete concentrations of total nitrogen at eight sites in the Upper Yampa River Basin, Colorado (CO), for various starting water years through water year 2018. "Discrete concentration" refers to the uncensored discrete data. "Discrete $(<)$ concentration" refers to values less than $(<)$ the method detection limit. "Discrete $(E)$ concentration" refers to values between the laboratory reporting limit and the method detection limit. (CDPHE, Colorado Department of Public Health and Environment) 


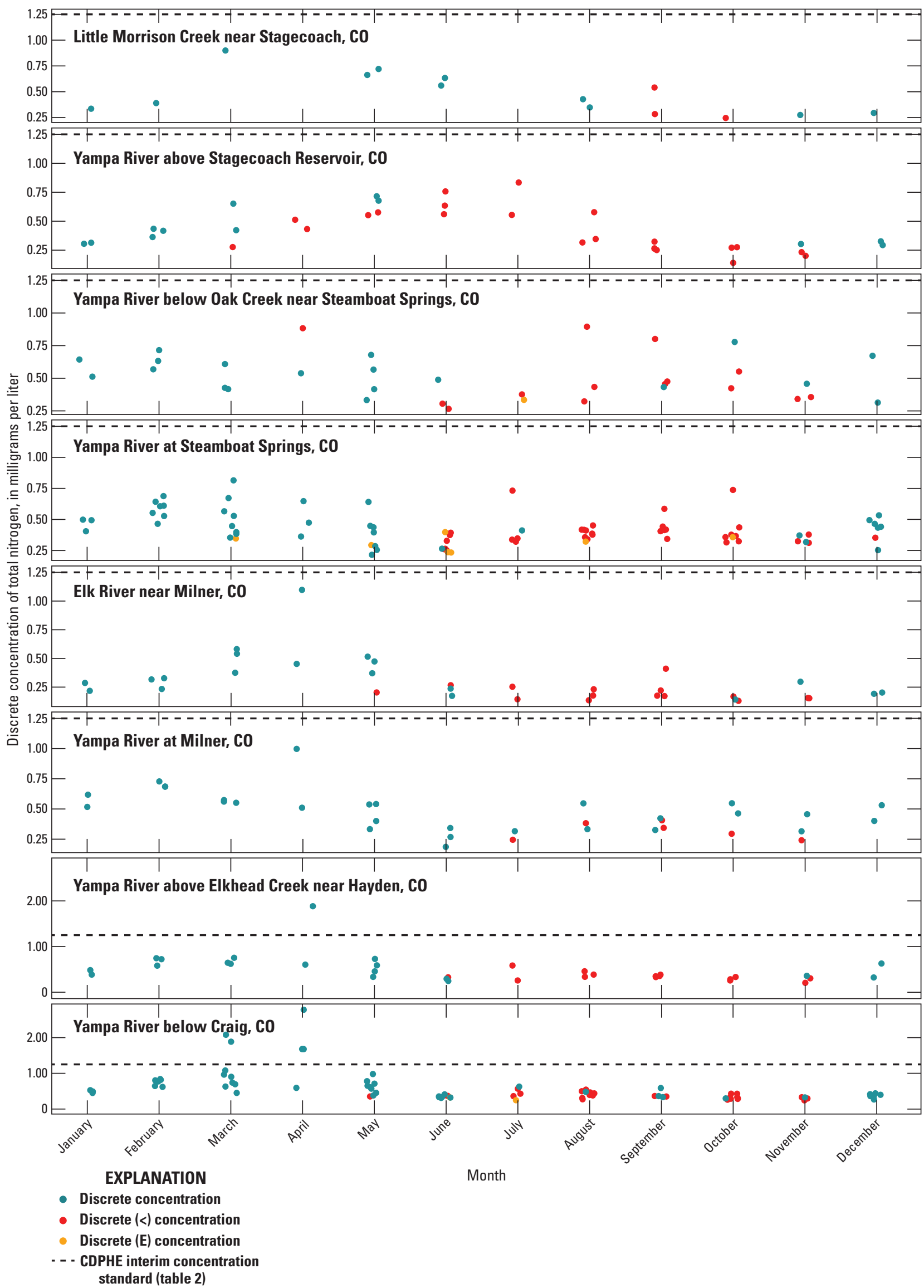




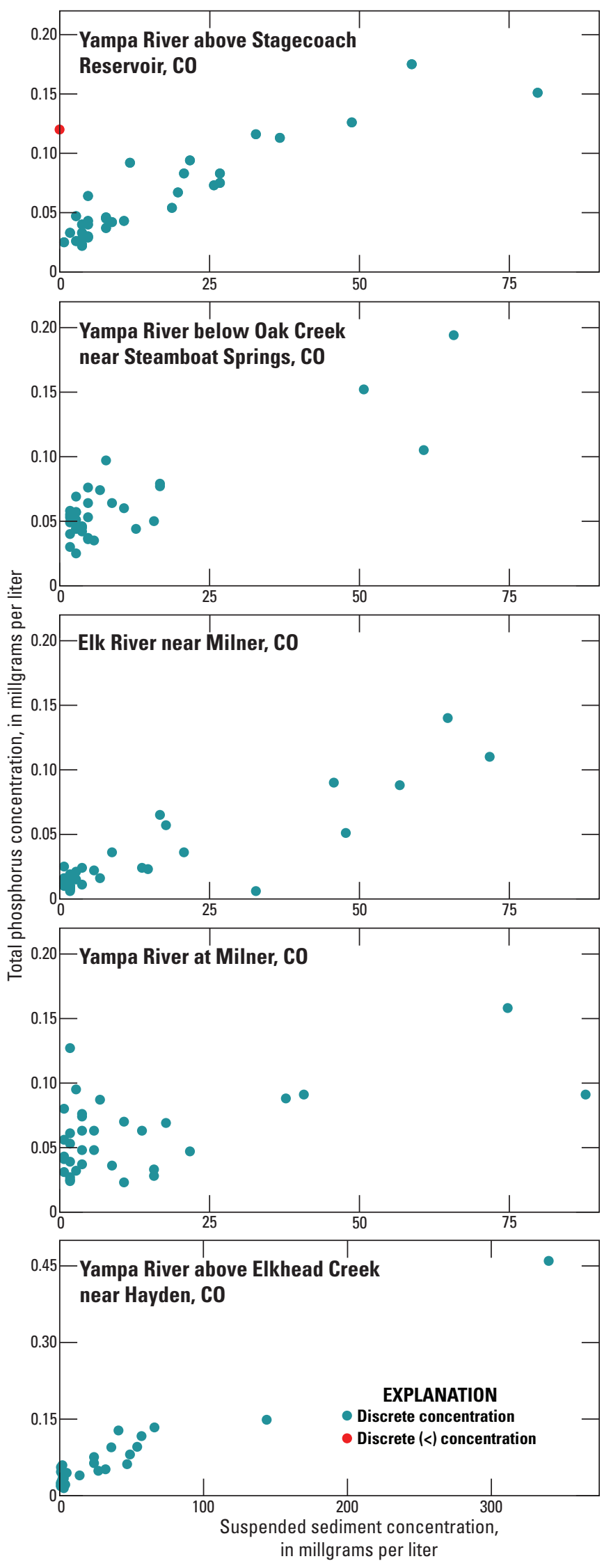

Figure 10. Graphs showing discrete concentrations of total phosphorus and suspended sediment at five sites in the Upper Yampa River Basin, Colorado (CO), for water years 2010-18. "Discrete concentration" refers to the uncensored discrete data. "Discrete $(<)$ concentration" refers to concentrations less than $(<)$ the method detection limit. 

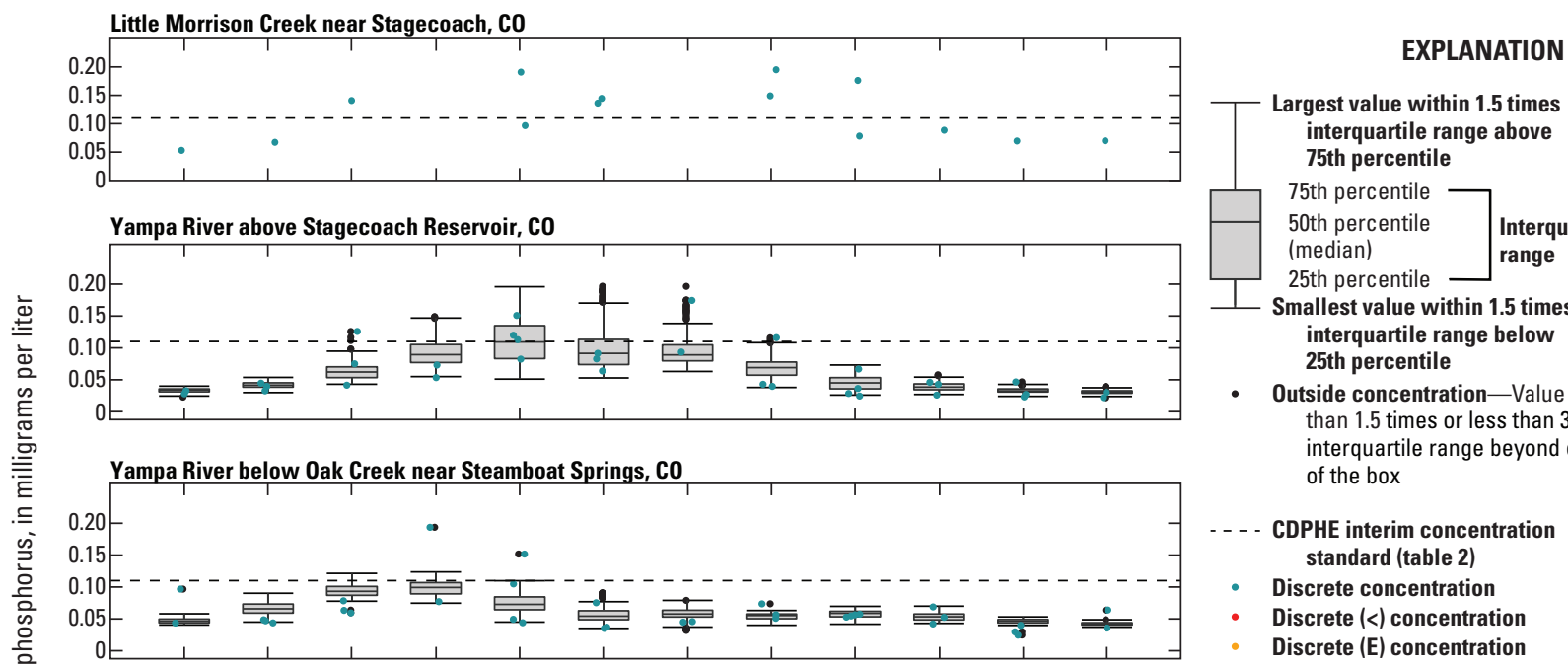

Discrete (E) concentration
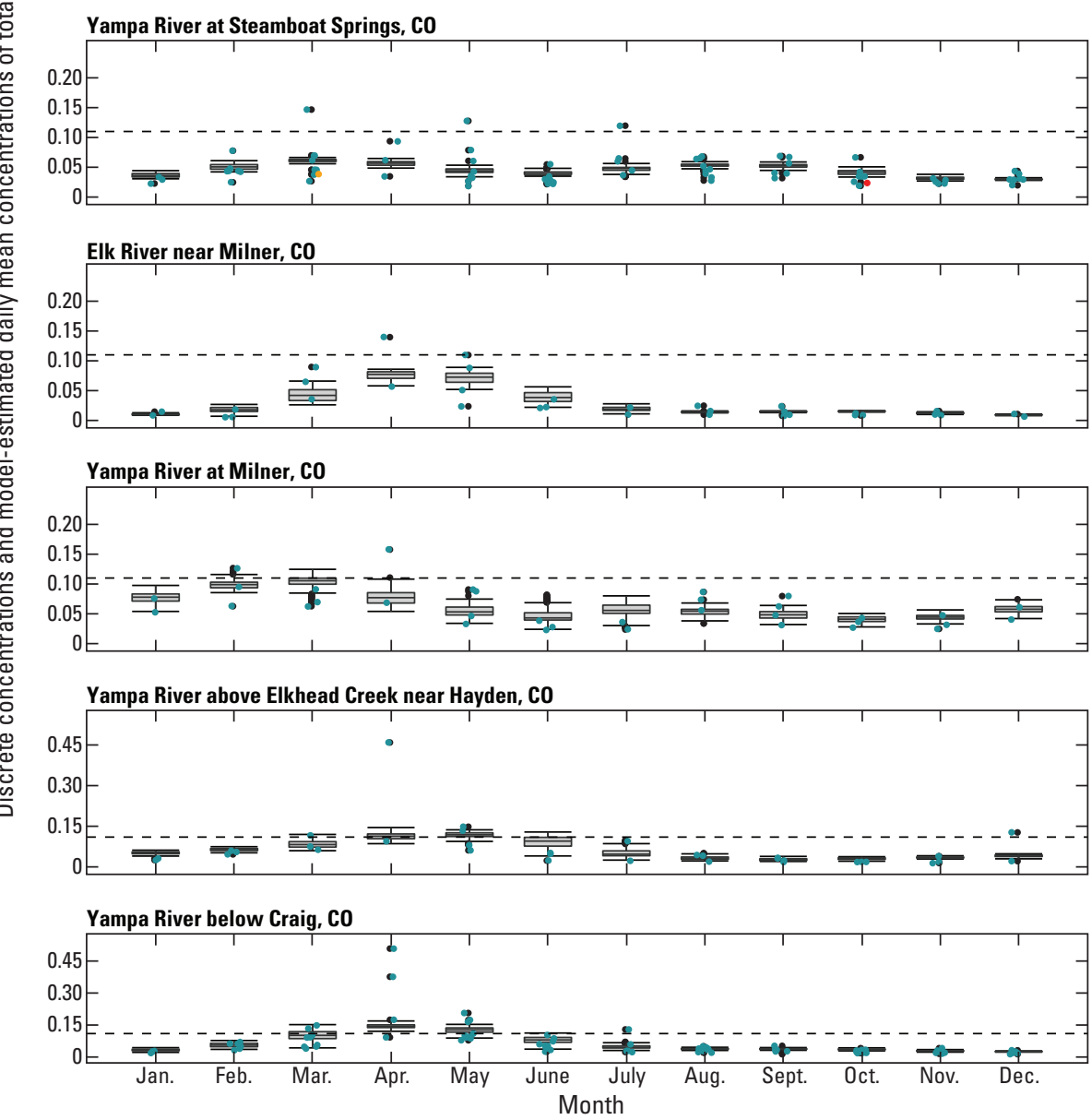

Figure 11. Discrete concentrations and boxplots of model-estimated daily mean concentrations of total phosphorus at eight sites in the Upper Yampa River Basin, Colorado (CO), for various starting water years through 2018. "Discrete concentration" refers to the uncensored discrete data. "Discrete $(<)$ concentration" refers to concentrations less than $(<)$ the method detection limit. "Discrete (E) concentration" refers to concentrations between the laboratory reporting limit and the method detection limit. (CDPHE, Colorado Department of Public Health and Environment) 
Creek. However, concentrations in one-half of discrete samples collected at the site exceeded the interim standard (fig. 11).

Seasonal variation in phosphorus concentrations differed among sites. Sites less affected by reservoir processes, including Yampa River above Stagecoach Reservoir and Little Morrison Creek, had longer peak durations of total phosphorus, with highest concentrations occurring later in the summer than sites downstream from the reservoir (fig. 11). Orthophosphate concentrations were also highest during summer months at Yampa River above Stagecoach Reservoir and Little Morrison Creek. Concentrations at Elk River near Milner were highest in March, April, and May during spring runoff, whereas concentrations at sites downstream from Stagecoach Reservoir, including Yampa River at Milner and Yampa River above Elkhead Creek, were highest in February and lowest during summer months (fig. 12).

\section{Load Estimation and Streamflow-Normalized Load and Yield Analysis}

Management of water quality in receiving waters is complicated because sources of sediment and nutrients vary by type, magnitude, and location, and are distributed over large areas. Load calculations are useful for estimating inputs from source areas for a given water-quality constituent. Comparisons of loads among sites allow the user to determine what reaches of a river are the largest contributors of a given constituent. Recognizing increases or decreases in load along a stream reach can assist land managers in identifying point and nonpoint sources. Identifying areas with higher yields of a given constituent can help land managers target load-reduction strategies to specific areas.

This section is focused on loads and yields of suspended sediment for 5 sites, and Kjeldahl nitrogen and total phosphorus for 7 sites. Regression model coefficients and the overall fit of models for suspended sediment, Kjeldahl nitrogen, and total phosphorus loads are discussed. For 2 sites, constituent loads were analyzed for WYs 1999-2018, and for 5 sites, constituent loads were analyzed for WYs 2010-18 (table 1). Streamflow normalized monthly loads and net annual yields of these constituents were determined for WYs 2010-18 and are discussed and shown in tabular form. Annual loads and net yields based on a normalized hydrograph of suspended sediment, Kjeldahl nitrogen, total phosphorus, and orthophosphate are discussed and shown graphically.

\section{Suspended Sediment}

Each of the five sites analyzed for suspended sediment loads had adjusted $R^{2}$ values $>0.91$, except Yampa River above Stagecoach Reservoir, which had an adjusted $R^{2}$ value of 0.51 (table 4). Annual suspended sediment loads increased in a downstream direction (table 6, fig. 13). Loads were highest during spring runoff in May and June and lowest during the base flow from September through February (table 6). The largest change in load (61,000-ton increase) occurred between Yampa River at Milner and Yampa River above Elkhead Creek (table 6, fig. 13). The largest yields of suspended sediment (130 tons per square mile $\left[\mathrm{t} / \mathrm{mi}^{2}\right]$ ) occurred at Yampa River at Elkhead Creek (table 6, fig. 13).

\section{Nitrogen}

All seven sites had adjusted $R^{2}$ values for loads of Kjeldahl nitrogen greater than or equal to 0.93 (table 4). Annual Kjeldahl nitrogen loads in the Yampa River generally increased in a downstream direction (table 6, fig. 13). Loads were highest during spring runoff in May and June and lowest during the base flow from September through February (table 6). The largest change in the Kjeldahl nitrogen annual load (205-ton increase) occurred between Yampa River at Milner and Yampa River above Elkhead Creek (table 6). The largest yield of Kjeldahl nitrogen $\left(0.57 \mathrm{t} / \mathrm{mi}^{2}\right)$ occurred at Yampa River at Milner (table 6, fig. 13).

\section{Phosphorus}

All seven sites had adjusted $R^{2}$ values for loads of total phosphorus greater than or equal to 0.90 (table 4). Annual total phosphorus loads increased in a downstream order (fig. 13). Loads at Yampa River sites were highest during high streamflow during May and June (table 6). Like Kjeldahl nitrogen, the largest change in annual load (58-ton increase) occurred between Yampa River at Milner and Yampa River above Elkhead Creek (table 6, fig. 13). The largest yields of total phosphorus occurred at Yampa River at Milner (0.10 t/ $\left.\mathrm{mi}^{2}\right)$ and Yampa River at Elkhead Creek $\left(0.13 \mathrm{t} / \mathrm{mi}^{2}\right)$ (table 6, fig. 13).

\section{Concentration and Load Trend Analysis}

Tracking sediment and nutrient concentration and load trends across a basin can help identify nutrient source areas and patterns of nutrient transport and delivery changes across the region. Trends in concentrations and loads can be caused by changes in land management, land use, and climate, or a combination of these factors (Lorenz and others, 2009). Two methods were used to assess trends in water quality from WY 1999 to WY 2018. Trends in concentrations and loads of suspended sediment were assessed using multiple linear regression models at 5 sites and trends in Kjeldahl nitrogen and total phosphorus were assessed at 7 sites. An additional method for assessing trends, using a weighted regression technique, was applied at 2 sites, Yampa River at Steamboat Springs and Yampa River below Craig, that met the recommended criterion for using WRTDS, which is a minimum of 60 observations with sampling sufficiently representative of seasonal variation in concentration and streamflow. The strengths of this method compared to the multiple linear regression method include the 


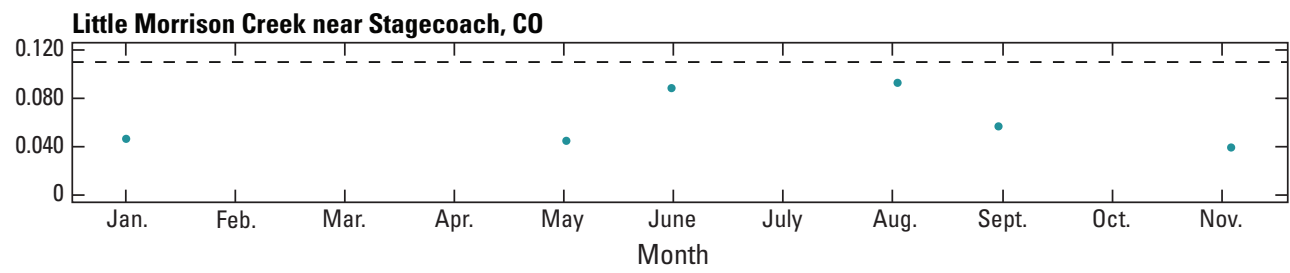

EXPLANATION

- - - CDPHE interim concentration standard (table 2)

- Discrete concentration

- Discrete $(<)$ concentration

- Discrete (E) concentration
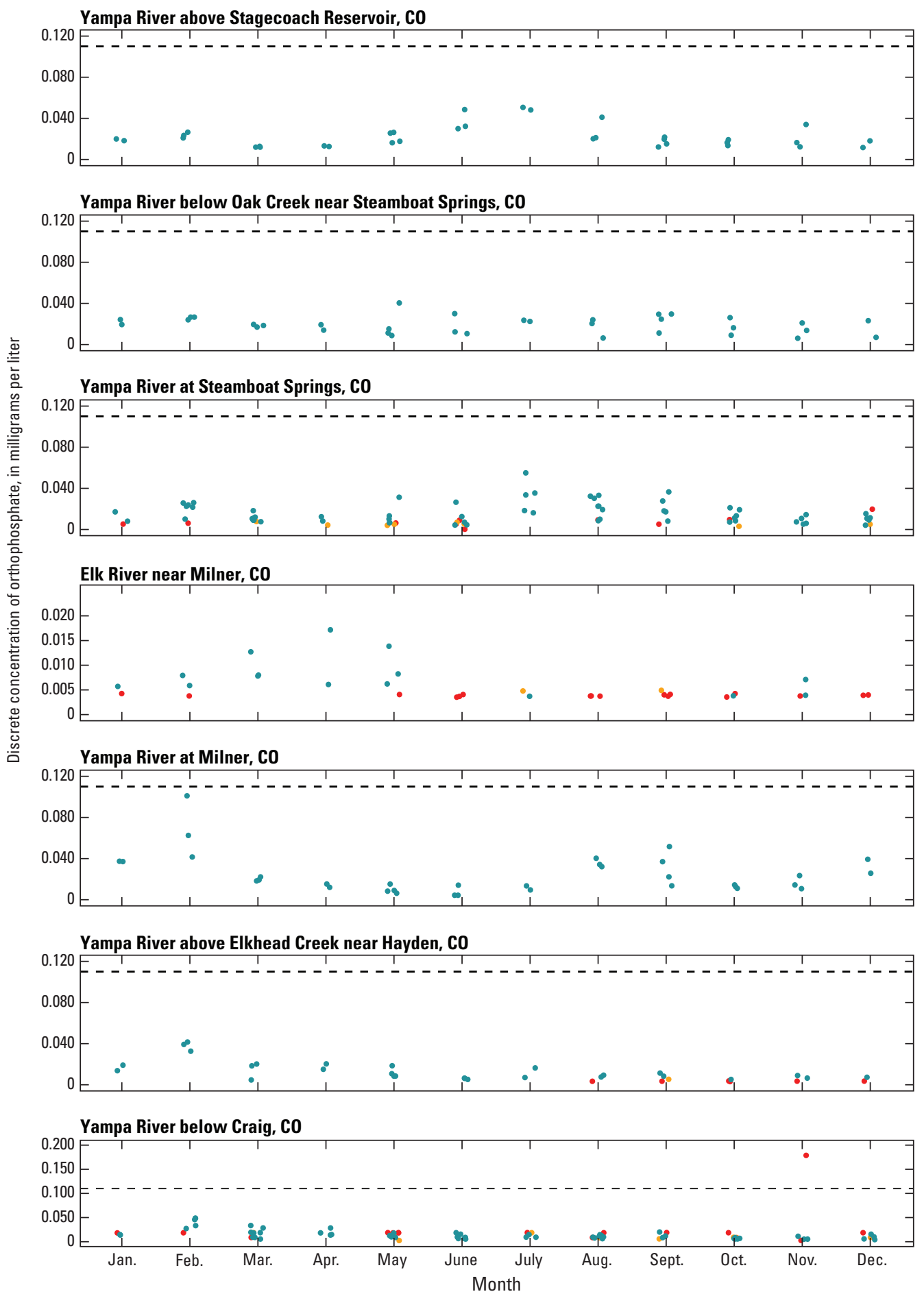

Figure 12. Graphs of discrete concentrations of orthophosphate at eight sites in the Upper Yampa River Basin, Colorado (CO), for various starting water years through 2018. "Discrete concentration" refers to the uncensored discrete data. "Discrete $(<)$ concentration" refers to concentrations less than $(<)$ the method detection limit. "Discrete $(E)$ concentration" refers to concentrations between the laboratory reporting limit and the method detection limit. (CDPHE, Colorado Department of Public Health and Environment) 
Table 6. Estimated monthly and annual loads and annual yields, based on normalized hydrographs, of suspended sediment for 5 sites, and Kjeldahl nitrogen and total phosphorus for 7 sites listed in downstream order in the Upper Yampa River Basin, Colorado (CO), for water years 2010-18, and changes in annual loads at Yampa River sites.

[USGS, U.S. Geological Survey; Jan, January; Feb, February; Mar, March; Apr, April; Jun, June; Jul, July; Aug, August; Sept, September; Oct, October; Nov, November; Dec, December, NA, not applicable]

\begin{tabular}{|c|c|c|c|c|c|c|c|c|c|c|c|c|c|c|c|}
\hline \multirow{3}{*}{ USGS site name } & \multicolumn{14}{|c|}{ Load, in tons } & \multirow{3}{*}{$\begin{array}{c}\text { Yield, in tons } \\
\text { per square mile } \\
\text { Annual }\end{array}$} \\
\hline & \multicolumn{12}{|c|}{ Month } & \multirow[b]{2}{*}{ Annual } & \multirow{2}{*}{ Change $^{\mathrm{a}}$} & \\
\hline & Jan & Feb & Mar & Apr & May & Jun & Jul & Aug & Sept & Oct & Nov & Dec & & & \\
\hline & \multicolumn{15}{|c|}{ Suspended sediment } \\
\hline $\begin{array}{l}\text { Yampa River above Stagecoach } \\
\text { Reservoir, CO }\end{array}$ & 34 & 33 & 96 & 230 & 330 & 200 & 252 & 120 & 52 & 71 & 56 & 40 & 1,500 & NA & 7.3 \\
\hline $\begin{array}{l}\text { Yampa River below Oak Creek near } \\
\text { Steamboat Springs, CO }\end{array}$ & 24 & 36 & 150 & 820 & 2,000 & 900 & 86 & 25 & 21 & 34 & 35 & 26 & 4,100 & 2,600 & 10 \\
\hline Elk River near Milner, CO & 32 & 34 & 220 & 1,700 & 6,600 & 5,600 & 490 & 28 & 12 & 32 & 34 & 30 & 15,000 & NA & 32 \\
\hline Yampa River at Milner, CO & 46 & 83 & 600 & 4,300 & 12,000 & 7,400 & 620 & 83 & 59 & 100 & 75 & 44 & 25,000 & 10,000 & 120 \\
\hline \multirow[t]{2}{*}{$\begin{array}{l}\text { Yampa River above Elkhead Creek } \\
\text { near Hayden, CO }\end{array}$} & 91 & 89 & 740 & 7,600 & 36,000 & 38,000 & 3,100 & 180 & 72 & 210 & 180 & 100 & 86,000 & 61,000 & 130 \\
\hline & \multicolumn{15}{|c|}{ Kjeldahl nitrogen } \\
\hline $\begin{array}{l}\text { Yampa River above Stagecoach } \\
\text { Reservoir, CO }\end{array}$ & 0.71 & 0.76 & 1.9 & 4.6 & 7.6 & 6.0 & 6.2 & 2.8 & 1.1 & 1.1 & 0.89 & 0.74 & 35 & NA & 0.17 \\
\hline $\begin{array}{l}\text { Yampa River below Oak Creek near } \\
\text { Steamboat Springs, } \mathrm{CO}^{\mathrm{b}}\end{array}$ & 2.5 & 2.8 & 5.9 & 16 & 34 & 24 & 6.4 & 4.0 & 3.9 & 4.7 & 3.9 & 2.8 & 111 & 77 & 0.30 \\
\hline $\begin{array}{l}\text { Yampa River at Steamboat Springs, } \\
\text { CO }\end{array}$ & 2.7 & 2.8 & 68 & 20 & 44 & 41 & 11 & 5.0 & 3.9 & 5.2 & 4.0 & 3.0 & 149 & 38 & 0.37 \\
\hline Elk River near Milner, $\mathrm{CO}^{\mathrm{b}}$ & 0.77 & 1.0 & 5.3 & 26 & 62 & 47 & 9.2 & 1.9 & 1.4 & 2.3 & 1.6 & 0.89 & 160 & NA & 0.35 \\
\hline Yampa River at Milner, $\mathrm{CO}^{\mathrm{b}}$ & 5.0 & 6.2 & 18 & 58 & 113 & 92 & 25 & 9.1 & 7.5 & 10 & 7.6 & 5.3 & 357 & 47 & 0.57 \\
\hline $\begin{array}{l}\text { Yampa River above Elkhead Creek } \\
\text { near Hayden, CO }\end{array}$ & 6.5 & 6.1 & 19 & 75 & 184 & 186 & 44 & 9.0 & 5.5 & 10 & 9.3 & 6.9 & 562 & 205 & 0.45 \\
\hline \multirow[t]{2}{*}{ Yampa River below Craig, CO } & 5.0 & 7.2 & 33 & 119 & 206 & 152 & 34 & 9.2 & 6.7 & 9.4 & 6.7 & 4.6 & 593 & 31 & 0.01 \\
\hline & \multicolumn{15}{|c|}{ Total phosphorus } \\
\hline $\begin{array}{l}\text { Yampa River above Stagecoach } \\
\text { Reservoir, CO }\end{array}$ & 0.11 & 0.12 & 0.37 & 0.90 & 1.4 & 0.94 & 1.0 & 0.46 & 0.19 & 0.19 & 0.14 & 0.11 & 5.9 & NA & 0.03 \\
\hline $\begin{array}{l}\text { Yampa River below Oak Creek near } \\
\text { Steamboat Springs, } \mathrm{CO}^{\mathrm{b}}\end{array}$ & 0.33 & 0.44 & 1.1 & 3.0 & 5.8 & 3.7 & 0.90 & 0.48 & 0.42 & 0.48 & 0.41 & 0.32 & 17 & 11 & 0.05 \\
\hline $\begin{array}{l}\text { Yampa River at Steamboat Springs, } \\
\text { CO }\end{array}$ & 0.29 & 0.38 & 1.0 & 2.9 & 5.9 & 5.4 & 1.5 & 0.69 & 0.49 & 0.54 & 0.38 & 0.27 & 20 & 2.4 & 0.02 \\
\hline Elk River near Milner, $\mathrm{CO}^{\mathrm{b}}$ & 0.067 & 0.11 & 0.84 & 5.2 & 13 & 8.0 & 1.1 & 0.16 & 0.10 & 0.17 & 0.12 & 0.07 & 29 & NA & 0.09 \\
\hline Yampa River at Milner, $\mathrm{CO}^{\mathrm{b}}$ & 1.4 & 1.6 & 3.5 & 8.7 & 16 & 14 & 4.4 & 1.5 & 0.92 & 1.1 & 1.1 & 1.2 & 56 & 7.2 & 0.10 \\
\hline $\begin{array}{l}\text { Yampa River above Elkhead Creek } \\
\text { near Hayden, CO }\end{array}$ & 0.93 & 1.1 & 4.3 & 18 & 43 & 36 & 6.0 & 0.85 & 0.43 & 0.85 & 0.86 & 0.78 & 113 & 58 & 0.13 \\
\hline Yampa River below Craig, CO & 0.63 & 1.0 & 6.4 & 28 & 51 & 33 & 5.1 & 0.98 & 0.64 & 0.99 & 0.73 & 0.52 & 130 & 16 & 0.03 \\
\hline
\end{tabular}

${ }^{a}$ "Change" is difference in load from the upstream Yampa River site.

bEstimated hydrograph used in linear regression model, limitations are discussed in "Extension of Streamflow Record" section. 
ability to identify nonmonotonic trend patterns and the ability to differentiate between trends in concentration versus trends in load. The likelihood designations used to describe trends follow the pattern used by Hirsch and others (2015) and are described in the "Weighted Regression Trend Analysis" section. The weighted regression model coefficients and statistical diagnostics are presented in tabular form, and the estimated annual concentrations and loads and associated slopes are shown in graphical form, in this section.

\section{Suspended Sediment}

The time coefficient (t-t*) was not included in linear regression models for suspended sediment because it was not statistically significant ( $p$-value $>0.1$ ) for any of the five sites evaluated, which indicates that trends in suspended sediment concentrations and loads were not identified using this method (tables 3 and 4). The weighted regression technique could not be used at Yampa River at Steamboat Springs or Yampa River below Craig because suspended sediment data were only available for years prior to 1992 .

\section{Nitrogen}

The time coefficient $\left(\mathrm{t}-\mathrm{t}^{*}\right)$ was not included in linear regression models for Kjeldahl nitrogen because it was not statistically significant ( $\mathrm{p}$-value $>0.1$ ) for any of the seven sites evaluated, which indicates that trends in Kjeldahl nitrogen concentrations and loads were not identified using this method (tables 3 and 4). A highly likely upward trend in the streamflow-normalized Kjeldahl nitrogen concentration and load from WY 1999 to WY 2018 was indicated at Yampa River at Steamboat Springs (table 7) using the weightedregression trend analysis. The Kjeldahl nitrogen concentration likely increased by 10 percent, or $0.035 \mathrm{mg} / \mathrm{L}$, for the time period (table 7, fig. 14A). The Kjeldahl nitrogen load also likely increased by 22 percent, or 26 tons, from WY 1999 to WY 2018. No trends were identified for Kjeldahl nitrogen concentrations and loads at Yampa River below Craig from WY 1999 to WY 2018 (table 7).

\section{Phosphorus}

The time coefficient $\left(\mathrm{t}-\mathrm{t}^{*}\right)$ was not included in linear regression models for total phosphorus because it was not statistically significant ( $\mathrm{p}$-value $>0.1$ ) for any of the seven sites evaluated, which indicates that trends in total phosphorus concentrations and loads were not identified using this method (tables 3 and 4). However, the weighted regression technique indicated a highly likely upward trend in streamflow-normalized concentration and load from WY 1999 to WY 2018 at Yampa River at Steamboat Springs (table 7). Total phosphorus concentration likely increased by 1.1 percent per year and 20 percent, or $0.0081 \mathrm{mg} / \mathrm{L}$, across the time period (table 7, fig. 14B). Bauch and others
(2012) reported a statistically significant upward trend in phosphorus concentration from 1997 to 2008 at Yampa River at Steamboat Springs, with an estimated rate of change of 3.1 percent per year, or $0.001 \mathrm{mg} / \mathrm{L}$ per year. The Bauch and others (2012) report indicated that the upward trend may have reflected population growth and related land-use changes that occurred upstream from the site. Loads also likely increased by 2.1 percent per year and 41 percent, or 6.2 tons, across the time period (table 7). Trends were not indicated for total phosphorus concentrations and loads at Yampa River below Craig from WY 1999 to WY 2018 (table 7).

\section{Stagecoach Reservoir Water Quality and Algae}

Factors like variations in climate, natural processes, and land use in the basin can affect hydrologic and chemical characteristics of reservoirs, and indirectly affect the biological community. Among the most common factors affecting reservoir water quality is eutrophication, the enrichment of reservoir water with nutrients, organic matter, and silt. Eutrophic conditions can lead to extensive and rapid growth of planktonic algae. Excessive algal growth reduces water clarity, inhibits growth of other plants, and can lead to extensive oxygen depletion, accumulation of unsightly and decaying organic matter, unpleasant odors, and fish kills. Cyanobacteria, a type of photosynthetic bacteria that is also known as bluegreen algae, can proliferate in reservoirs that exhibit eutrophic conditions and hydrologic alterations, as demonstrated by the increasingly frequent and highly visible cyanobacterial harmful algal blooms (CyanoHABs) in lakes and reservoirs around the world (Paerl and Otten, 2013). Cyanotoxins, produced by cyanobacteria, include liver, nerve, and skin toxins that can affect human and animal health. Potential exposure routes to cyanotoxins include contact, ingestion, or inhalation during recreational activities, drinking contaminated water, and ingesting crops irrigated by contaminated water (Chorus and Bartram, 1999; Corbel and others, 2014).

Selected physical and chemical characteristics of water samples collected at two depths once a month from July to September in 2017 and 2018 at Stagecoach Reservoir at Dam, Colo. (USGS site number 401707106495800), herein referred to as "Stagecoach Reservoir at Dam," are presented graphically and discussed in this section. Cell densities of planktonic algae and cyanotoxin concentrations from samples collected on same dates are compared to World Health Organization and U.S. Environmental Protection Agency guideline values to evaluate potential human recreational risks.

On multiple sampling events at Stagecoach Reservoir at Dam, the physical and chemical factors indicated conditions conducive to cyanobacterial blooms. Nutrient-enriched waterbodies are especially prone to CyanoHABs if they also have long residence times, water temperatures periodically exceeding 20 degrees Celsius, calm surface waters, and persistent vertical stratification (Paerl, 1988). In Stagecoach Reservoir, surface-water temperatures exceeded 20 degrees 


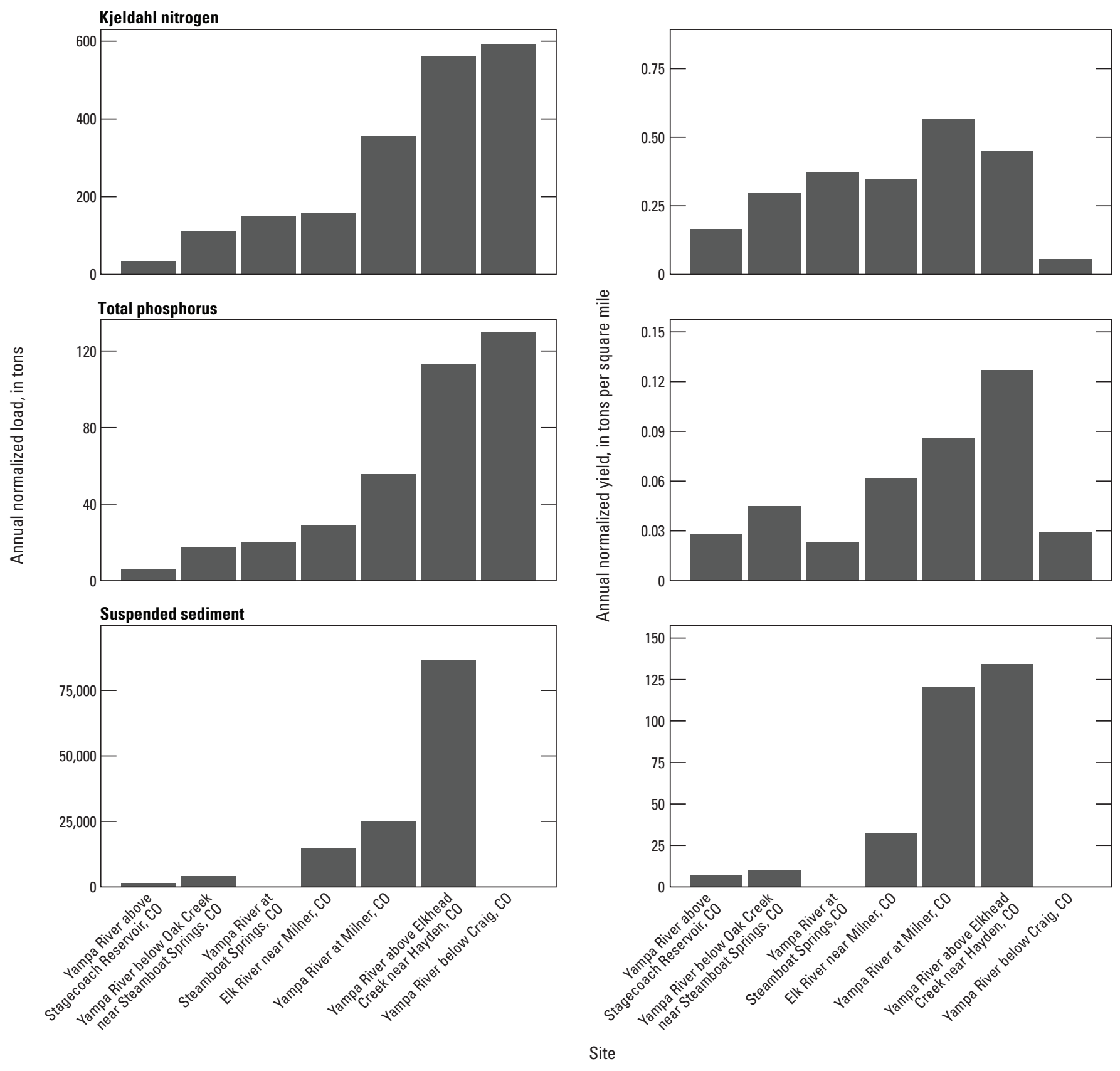

Figure 13. Graphs showing annual loads and net yields of suspended sediment, Kjeldahl nitrogen, and total phosphorus, based on normalized hydrographs at select sites in the Upper Yampa River Basin, Colorado (CO), for water years 2010-18. 
Table 7. Results of weighted-regression trend analysis and regression statistics for annual streamflow-normalized concentrations and loads at Yampa River at Steamboat Springs, Colorado (CO), and Yampa River below Craig, CO for water years 1999-2018.

[USGS, U.S. Geological Survey; No., number of samples included in analysis; p-value is significance statistic]

\begin{tabular}{|c|c|c|c|c|c|c|c|c|c|c|}
\hline USGS site name & Parameter & $\begin{array}{l}\text { Load } \\
\text { bias }\end{array}$ & $\begin{array}{c}\text { No. of } \\
\text { samples }\end{array}$ & $\begin{array}{c}\text { Trend slope, } \\
\text { units }\end{array}$ & $\begin{array}{c}\text { Trend slope, } \\
\text { units per } \\
\text { year }\end{array}$ & $\begin{array}{c}\text { Percent } \\
\text { change, } \\
\text { total }\end{array}$ & $\begin{array}{l}\text { Percent } \\
\text { change, } \\
\text { per year }\end{array}$ & p-value & $\begin{array}{l}\text { Likelihood } \\
\text { value }^{\mathrm{a}}\end{array}$ & $\begin{array}{c}\text { Trend } \\
\text { direction }^{\mathrm{a}}\end{array}$ \\
\hline \multicolumn{11}{|c|}{ Concentration, in milligrams per liter } \\
\hline $\begin{array}{l}\text { Yampa River } \\
\text { at Steamboat } \\
\text { Springs, CO }\end{array}$ & Kjeldahl nitrogen & -0.039 & 80 & 0.035 & 0.0018 & 10 & 0.55 & 0.15 & 0.93 & $\begin{array}{l}\text { Very likely } \\
\text { upwards }\end{array}$ \\
\hline $\begin{array}{l}\text { Yampa River below } \\
\text { Craig, CO }\end{array}$ & Kjeldahl nitrogen & -0.017 & 80 & 0 & 0 & 0 & 0 & 0.79 & 0.61 & Uncertain \\
\hline $\begin{array}{l}\text { Yampa River below } \\
\text { Craig, CO }\end{array}$ & Total phosphorus & -0.027 & 80 & 0.0045 & 0.00023 & 7.0 & 0.37 & 0.67 & 0.66 & Uncertain \\
\hline $\begin{array}{l}\text { Yampa River } \\
\text { at Steamboat } \\
\text { Springs, CO }\end{array}$ & Total phosphorus & 0.12 & 80 & 6.2 & 0.33 & 41 & 2.1 & 0.17 & 0.92 & $\begin{array}{c}\text { Very likely } \\
\text { upwards }\end{array}$ \\
\hline $\begin{array}{l}\text { Yampa River below } \\
\text { Craig, CO }\end{array}$ & Kjeldahl nitrogen & -0.017 & 80 & 24 & 1.3 & 4.2 & 0.22 & 0.83 & 0.57 & Uncertain \\
\hline $\begin{array}{l}\text { Yampa River below } \\
\text { Craig, CO }\end{array}$ & Total phosphorus & -0.027 & 80 & 0.51 & 0.027 & 0.36 & 0.019 & 0.99 & 0.48 & Uncertain \\
\hline
\end{tabular}

${ }^{a}$ Likelihood values and trend directions are computed from the two sided attained p-value and follow the pattern described in Hirsch and others (2015) where a range of likelihood values from 0.95 to 1.0 is considered "highly likely," 0.90 to $<0.95$ is "very likely," 0.67 to $<0.90$ is "likely," and 0.50 to $<0.67$ is "uncertain." 

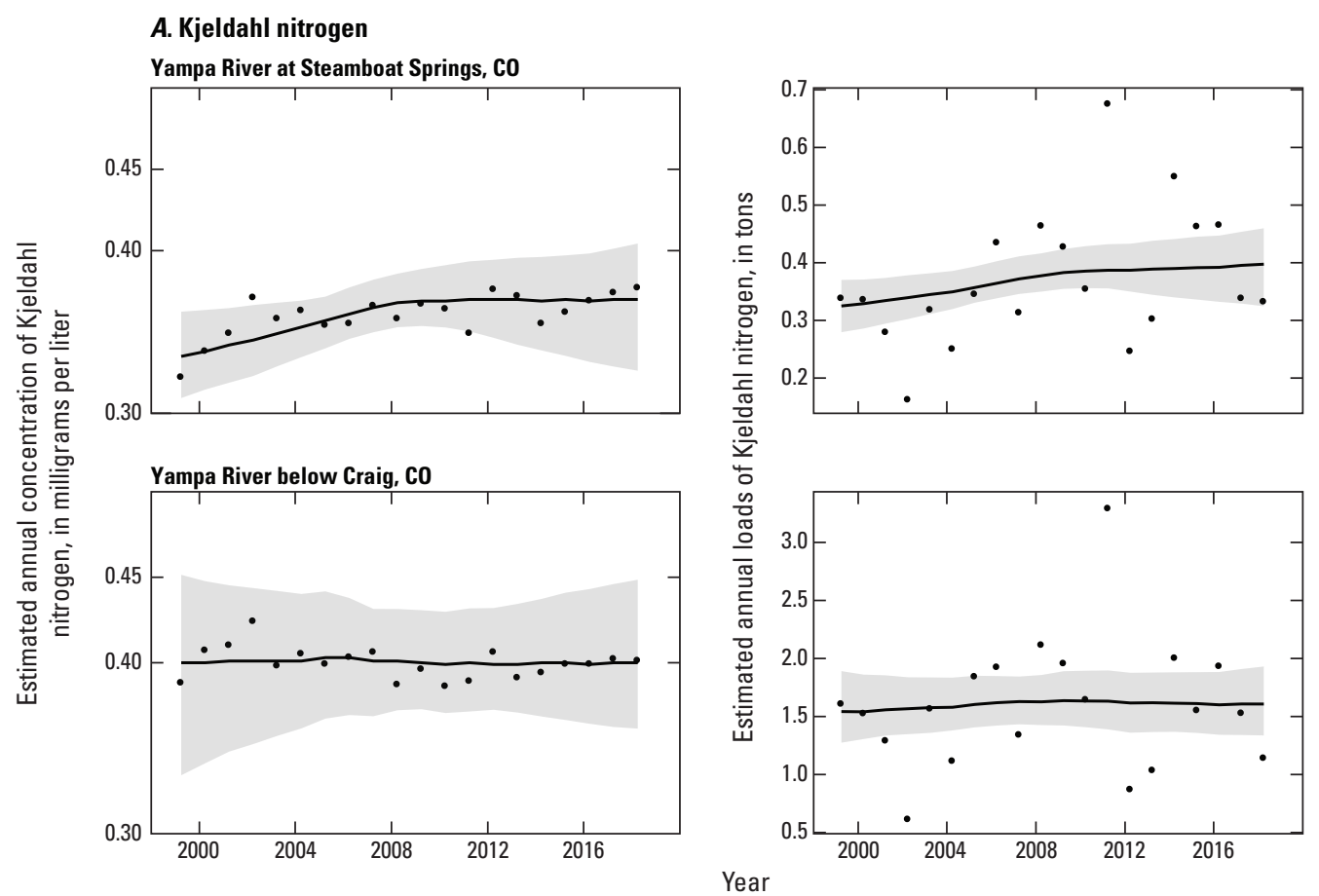

\section{EXPLANATION}

95 percent confidence interval of streamflow normalized trend

- Streamflow normalized trend

- Estimated annual value
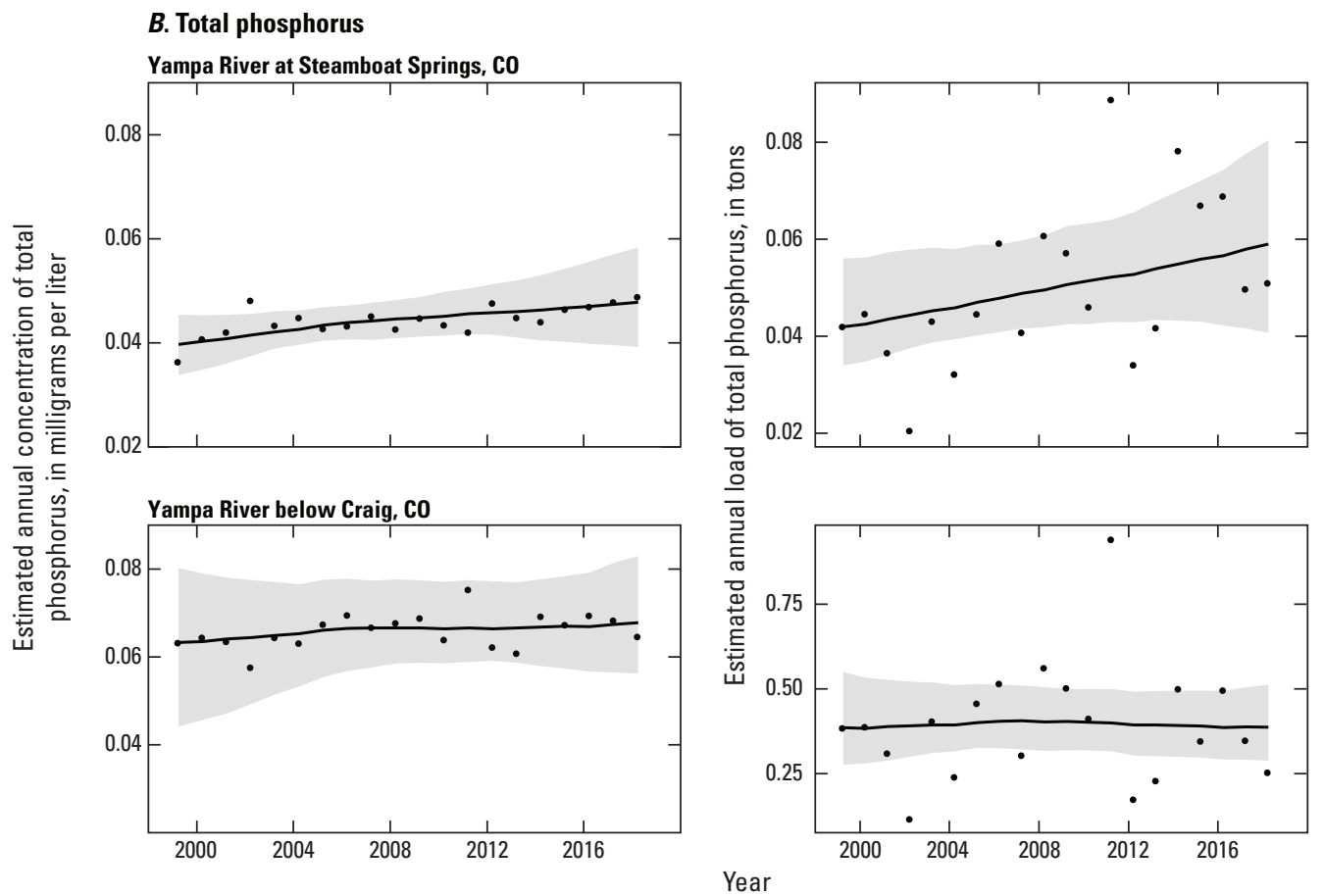

Figure 14. Graphs showing estimated annual concentrations and loads and streamflow-normalized trends for $A$, Kjeldahl nitrogen, and B, total phosphorus using weighted regression trend analysis at Yampa River at Steamboat Springs, Colorado (CO), and Yampa River at Craig, CO, in the Upper Yampa River Basin for water years 1999-2018. 
Celsius on sampling dates in July of 2017 and 2018 (fig. 15A). Anoxic conditions, which occur when dissolved-oxygen concentrations are $<0.5 \mathrm{mg} / \mathrm{L}$, were measured at all samples collected at depths of 114-120 feet (fig. 15B). Loss of oxygen is primarily because of oxygen consumption at the sediment-water interface, where bacterial decomposition of sediment organic matter is highest, and the use of oxygen by aquatic organisms in the water column (Wetzel, 1983). Phosphorus enrichment, especially relative to nitrogen enrichment, may favor the development of CyanoHABs, particularly those with nitrogen-fixing cyanobacteria (Smith and Schindler, 2009). These cyanobacteria can supply their own nitrogen by converting atmospheric nitrogen $\left(\mathrm{N}_{2}\right)$ to biologically available ammonia (Downing and others, 2001). Nitrogen-rich aquatic ecosystems can also have CyanoHABs, especially genera that do not fix atmospheric nitrogen (Paerl and Fulton, 2006). Most of the basin that drains into Stagecoach Reservoir overlies sedimentary rocks, which contribute dissolved materials to surface water (Terziotti and others, 2010). Total phosphorus concentrations in surface waters (3-feet depth) exceeded the interim CDPHE water-quality standard of $0.025 \mathrm{mg} / \mathrm{L}$ (table 2) in August and September of 2017 and 2018 (fig. 15C), whereas total nitrogen exceeded the interim standard of $0.426 \mathrm{mg} / \mathrm{L}$ (table 2) on every sampling date (fig. 15D). Chlorophyll $a$ concentration exceeded the CDPHE limit of $8.0 \mu \mathrm{g} / \mathrm{L}$ (table 2) on multiple sampling days (fig. 15F).

Total nitrogen to total phosphorus ratios (TN:TP) can be indicators of nutrient limitation in a body of water (Forsberg, 1979), and bloom-forming cyanobacteria tend to dominate in lakes where the TN:TP ratio is $<30$ (Smith, 1983). The $\mathrm{TN}$ :TP ratios in samples collected at 3 feet ranged from 15 to 31 (fig. 15E). One or more of the nitrogen constituents were less than the detection limit or estimated, resulting in multiple censored total nitrogen values and TN:TP ratios. Although many of the species constituting blooms in the reservoir are capable of nitrogen fixation, insufficient data exist to directly correlate nutrient limitation to species composition in blooms in Stagecoach Reservoir.

Cyanobacteria had the highest cell densities compared to other planktonic algae from samples collected at Stagecoach Reservoir at Dam. Total cyanobacterial cell densities ranged from 75 to $1,380,000$ cells per milliliter (cells $/ \mathrm{mL}$ ) and exceeded the World Health Organization guideline values for a moderate probability of adverse health effects (100,000 cells $/ \mathrm{mL}$ ) in July and August of 2017 (fig. 16; World Health Organization, 2003). As shown in figure 16, cyanobacterial genera that exceeded the guideline value were Aphanizomenon sp. $(1,380,000$ cells $/ \mathrm{mL})$, Cyanodictyon $\mathrm{sp}$. (238,000 cells/mL), and Chroococcus sp. (122,000 cells/ $\mathrm{mL})$. Other cyanobacterial genera present in the reservoir were Aphanocapsa sp., Microcystis sp., Planktolyngbya sp., Pseudanabaena sp., Rivularia sp., and Snowella sp. Many of these cyanobacterial genera can fix nitrogen. Other types of planktonic algae present in the reservoir included Bacillariophyta, Chlorophyta, Cryptophyta, Haptophyta, and Ochrophyta (Solberg, 2020).

Microcystins, a class of cyanotoxins, were detected at Stagecoach Reservoir at Dam in September 2018, but the total microcystins concentration of $0.26 \mu \mathrm{g} / \mathrm{L}$ was less than the U.S. Environmental Protection Agency recreational advisory level of $4 \mu \mathrm{g} / \mathrm{L}$ for microcystins (U.S. Environmental Protection Agency, 2016). The concentration of total microcystins was less than the detection limit of $0.10 \mu \mathrm{g} / \mathrm{L}$ on all other dates sampled. Two other types of cyanotoxins, total saxitoxins and total cylindrospermopsins, were also measured and were less than detection limits of 0.02 and $0.05 \mu \mathrm{g} / \mathrm{L}$, respectively, on all dates.

Increased nutrient import into reservoirs can lead to eutrophication and algae blooms; however, reservoirs have the potential to act as nutrient sinks or sources of nutrients, potentially reducing or enhancing nutrient loads downstream (Shaughnessy and others, 2019). Based on USGS NWIS data, mean concentrations of suspended sediment and Kjeldahl nitrogen, but not total phosphorus, were significantly lower in more recently collected data (WYs 2012-18) compared to data collected during the construction and filling of Stagecoach Reservoir (WYs 1989-93) at Yampa River above Stagecoach Reservoir. It is not clear why these decreases occurred. Mean concentrations for the two time periods differed by $109 \mathrm{mg} / \mathrm{L}$ for suspended sediment and $0.124 \mathrm{mg} / \mathrm{L}$ for Kjeldahl nitrogen. There were no differences in concentrations of Kjeldahl nitrogen or total phosphorus between more recently collected data and data collected during reservoir construction at Yampa River below Stagecoach Reservoir. There are no recent suspended sediment data for Yampa River below Stagecoach Reservoir. Thus, quantifying sediment storage in Stagecoach Reservoir, and the amount of sediment occurring from channel erosion downstream from the dam, is not possible.

\section{Changes in Land Use}

The dominant land cover in the UYRB in 2016 was forest, which accounted for 49 percent of total land area (27.5 percent deciduous, 18.6 percent evergreen, and 2.5 percent mixed forest; figs. 17 and 18). Other prominent land covers included shrub/scrub (39 percent), herbaceous (3.7 percent), and hay/pasture (3 percent). Development, including open space, only accounted for approximately 1.5 percent of land area in the UYRB. Land cover varied on a subbasin scale. In general, in 2016, the percentage of forest was greatest at sites farther upstream, and shrub/scrub cover was greatest at sites farther downstream (fig. 18). Developed land was greatest in the Yampa River at Steamboat Springs subbasin, where approximately 5 percent of the subbasin was developed (fig. 18).

Data from the National Land Cover Database were used to assess the cumulative change in forested and developed land-cover classes from 2001 to 2016 (Multi-Resolution Land 

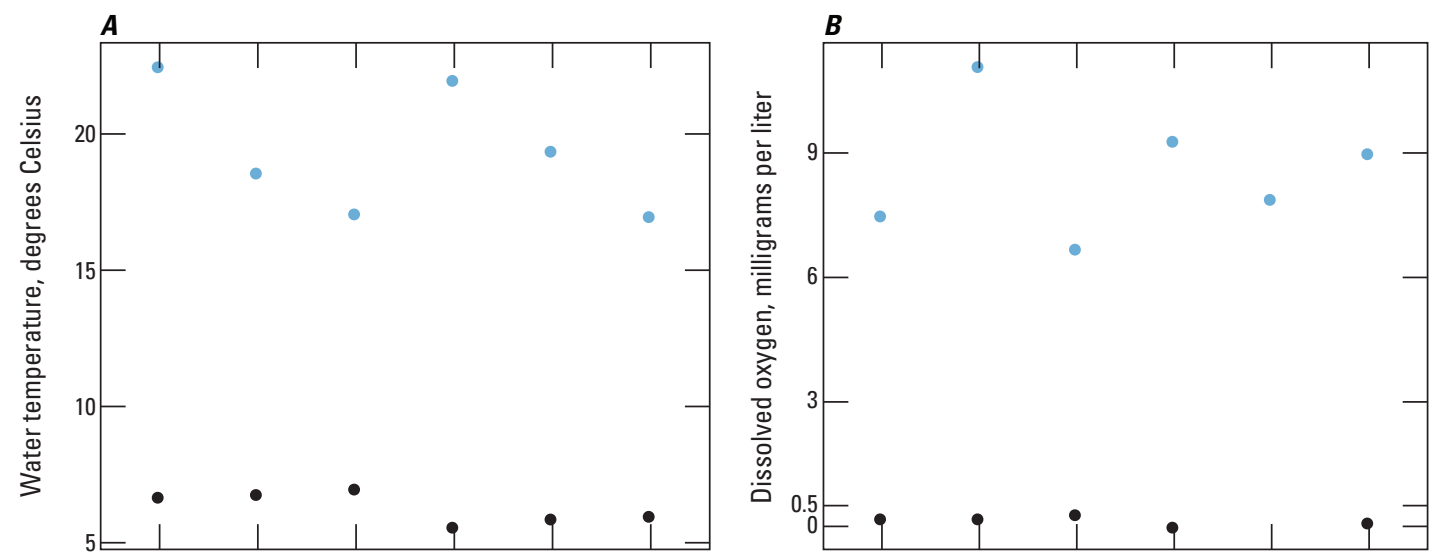

EXPLANATION

- - - CDPHE interim concentration standard (table 2)

Sample depth

- 3 feet

- 114 to 120 feet Data type

$\square \quad$ Discrete concentration

口 Discrete $(<)$ concentration
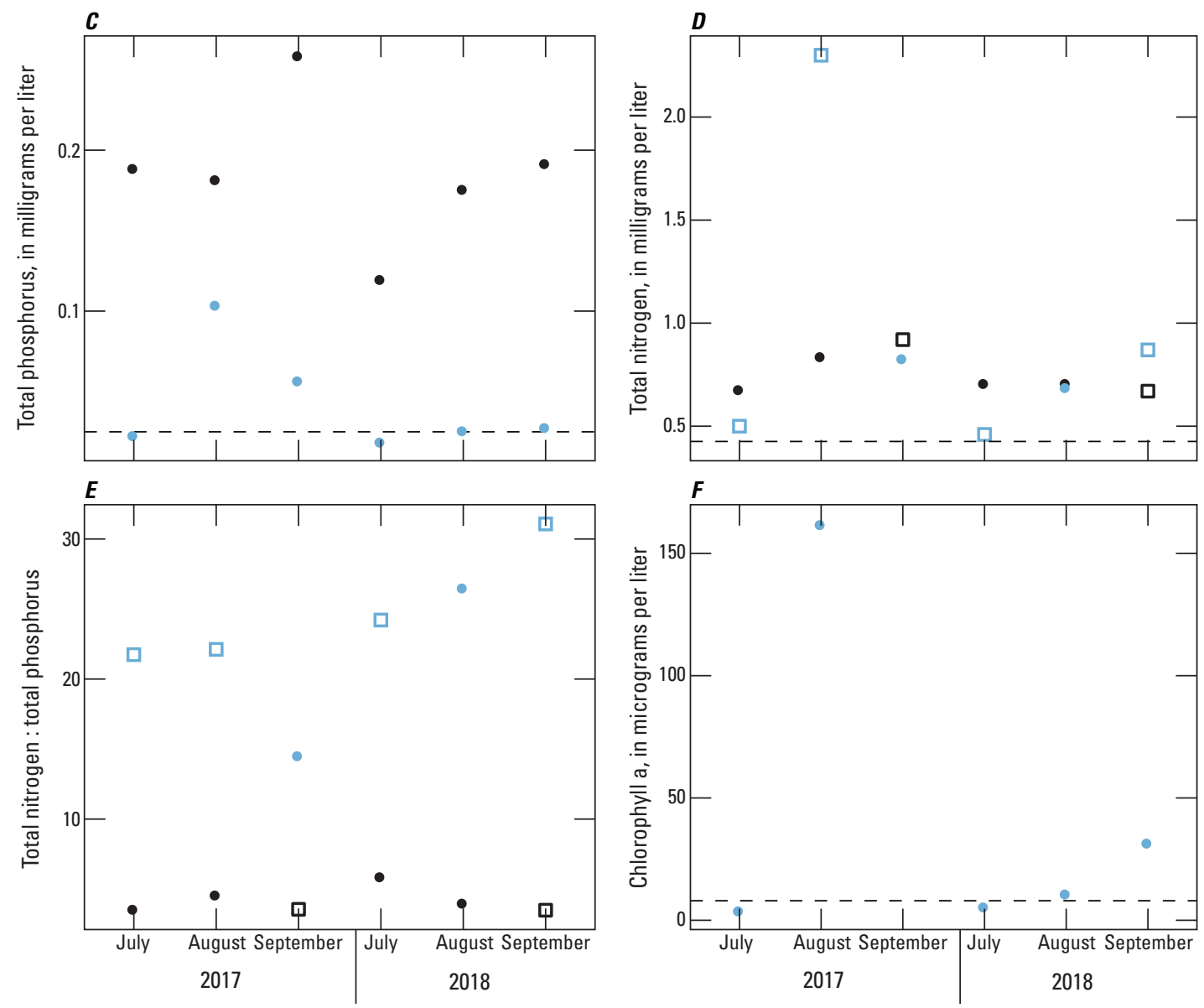

Figure 15. Graphs showing A, water temperature; B, dissolved oxygen concentration; C, total phosphorus concentration; D, total nitrogen concentration; $E$, ratio of total nitrogen to total phosphorus; and $F$, chlorophyll a concentrations at two depths at Stagecoach Reservoir at Dam, Colorado, in July-September 2017 and 2018. "Discrete concentration" refers to the uncensored discrete data. “Discrete $(<)$ concentration" refers to concentrations less than $(<)$ the method detection limit. (CDPHE, Colorado Department of Public Health and Environment). 


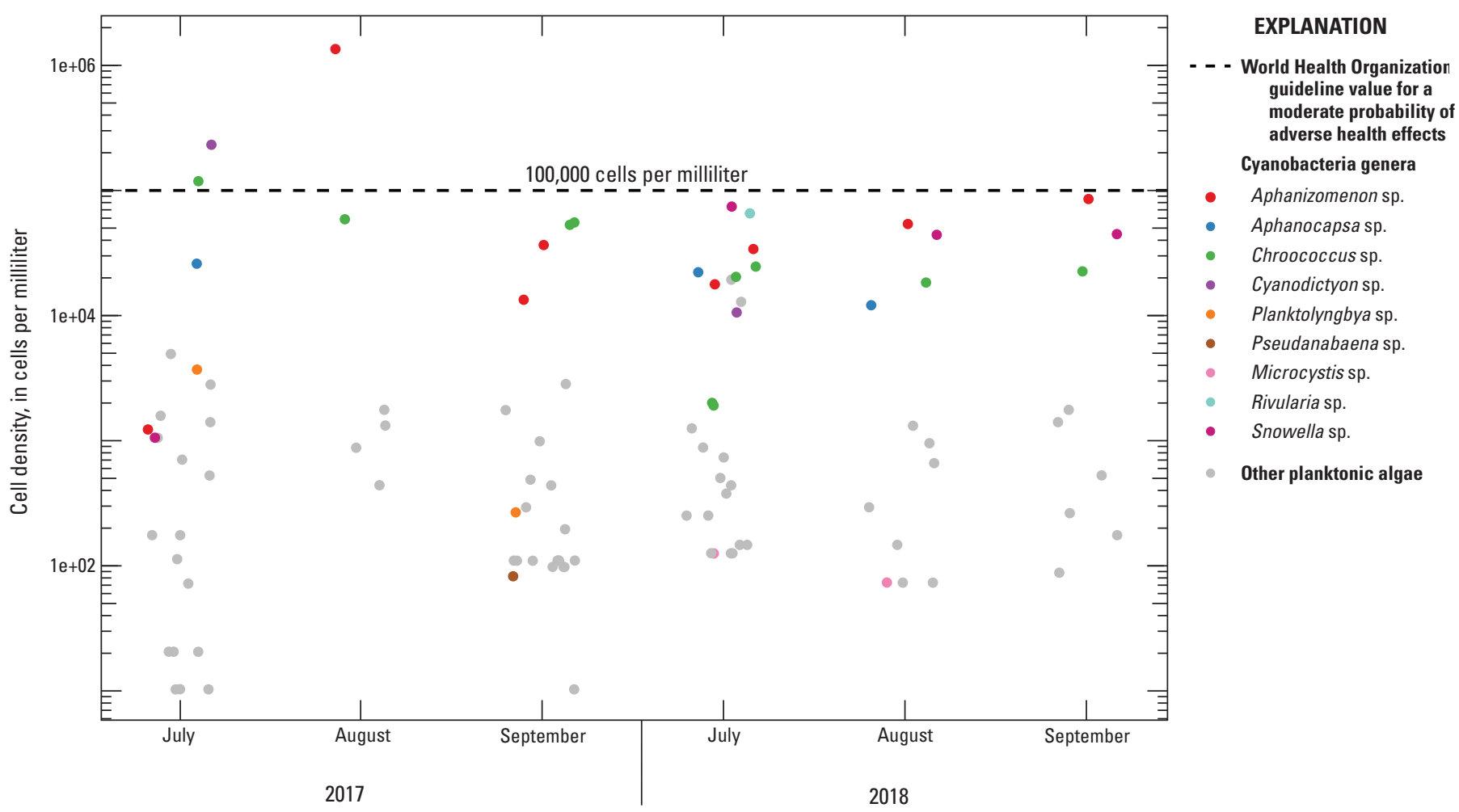

Figure 16. Graph showing planktonic algal cell densities, in cells per milliliter, in Stagecoach Reservoir at Dam, Colorado, in JulySeptember 2017 and 2018. “Other planktonic algae” includes all other planktonic algae. (sp., species)

Characteristics Consortium, 2020). In the UYRB, evergreen forest cover decreased by 26 square miles, representing 1.2 percent of the total basin area (table 8 ). Losses of evergreen forest were reported for the five subbasins upstream from the Yampa River at Milner site. Subbasins with the highest evergreen forest loss include Elk River near Milner (21 square miles or 4.6 percent of the relative area of the subbasin), and Yampa River below Oak Creek (4.2 square miles or 1.6 percent of relative area of the subbasin) (table 8). The largest proportion of these losses were between 2001 and 2004, during which time two wildland fires, the Mount Zirkel Complex and Green Creek fires, occurred in the two respective subbasins (Monitoring Trends in Burn Severity, 2020). In addition to fires, infestations of Dryocoetes confusus (western balsam bark beetle) and Dendroctonus rufipennis (spruce beetle) have resulted in substantial tree mortality in many forests in the UYRB (Colorado State Forest Service, 2019, 2020).

Developed land area, which includes high-, medium-, and low-density land development, increased by 0.79 square miles across the UYRB, with the largest increase of 0.39 square miles in the Yampa River at Steamboat Springs subbasin (table 8). It is important to consider that the resolution of the National Land Cover Database dataset is 900 square meters (Multi-Resolution Land Characteristics Consortium, 2020); thus, changes in land use less than that may not be captured in the dataset.

\section{Synthesis of Streamflow and Water-Quality Results}

The assessment of streamflow and surface-water quality in this study was designed to characterize and detect changes in streamflow and selected water-quality constituents in the UYRB and to help provide a better understanding of potential drivers of change, including land-use changes and differences in long-term basin characteristics, including geological features and land cover. The primary determinants of nutrient concentrations in water bodies are geological features, soil type, point-source inputs, and predominant catchment land use, which influences nonpoint-source contribution. Examples of point-source nutrient contributions include discharges from industrial sources and of effluent from municipal wastewater treatment plants. Nonpoint source nutrient contributions are often associated with anthropogenic activities including agriculture and urbanization. Changes in forested ecosystems, such as those caused by acidification from atmospheric deposition, wildfires, and insect infestation, can also affect nutrient inputs to receiving waterbodies (Monteith and others, 2007; Smith and others, 2011; Mikkelson and others, 2013).

Shorter-term changes to streamflows in the UYRB likely result from changes in water management, whereas longer-term changes reflect trends occurring across western 


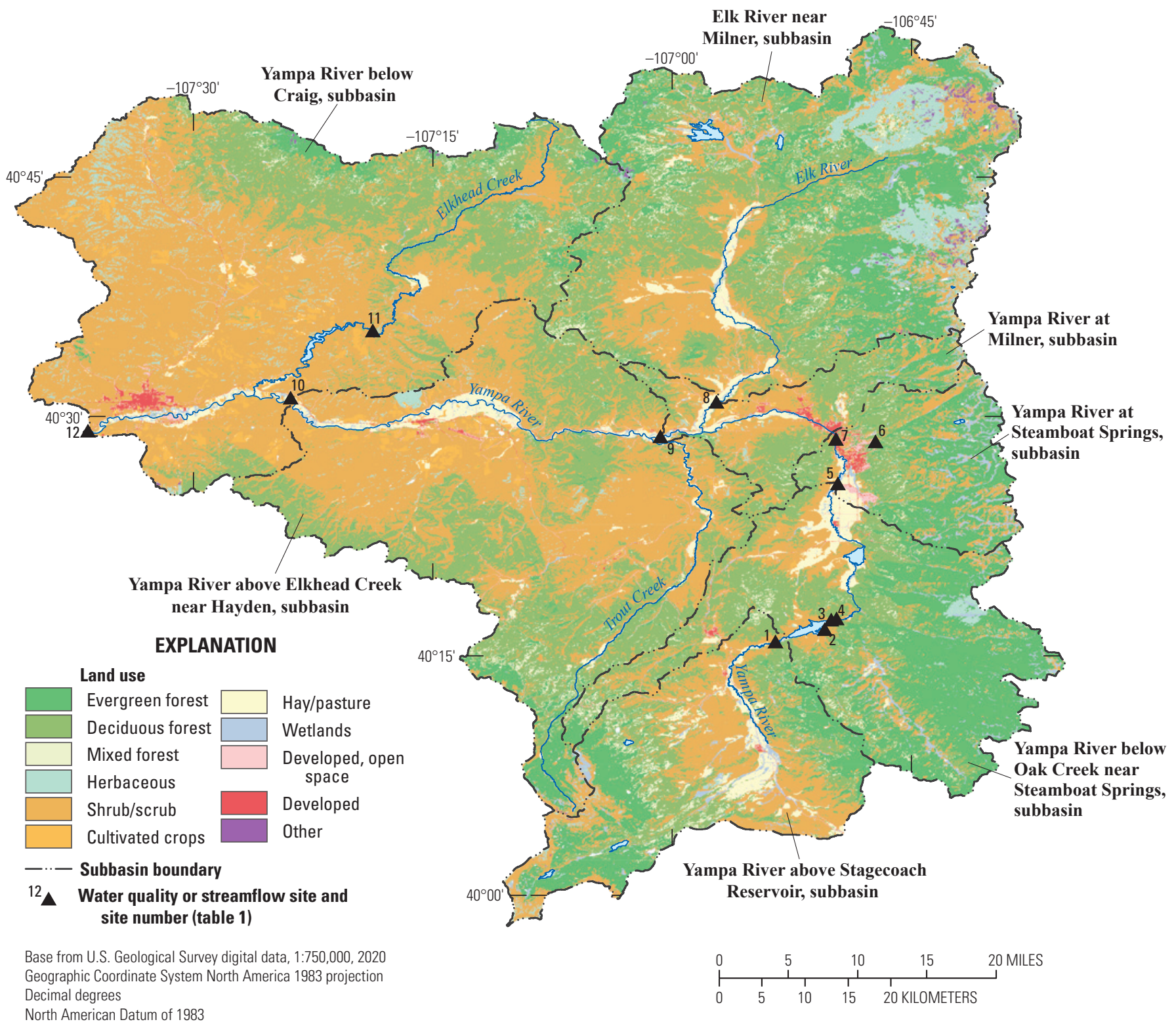

Figure 17. Map showing land cover in the Upper Yampa River Basin, Colorado, in 2016. 


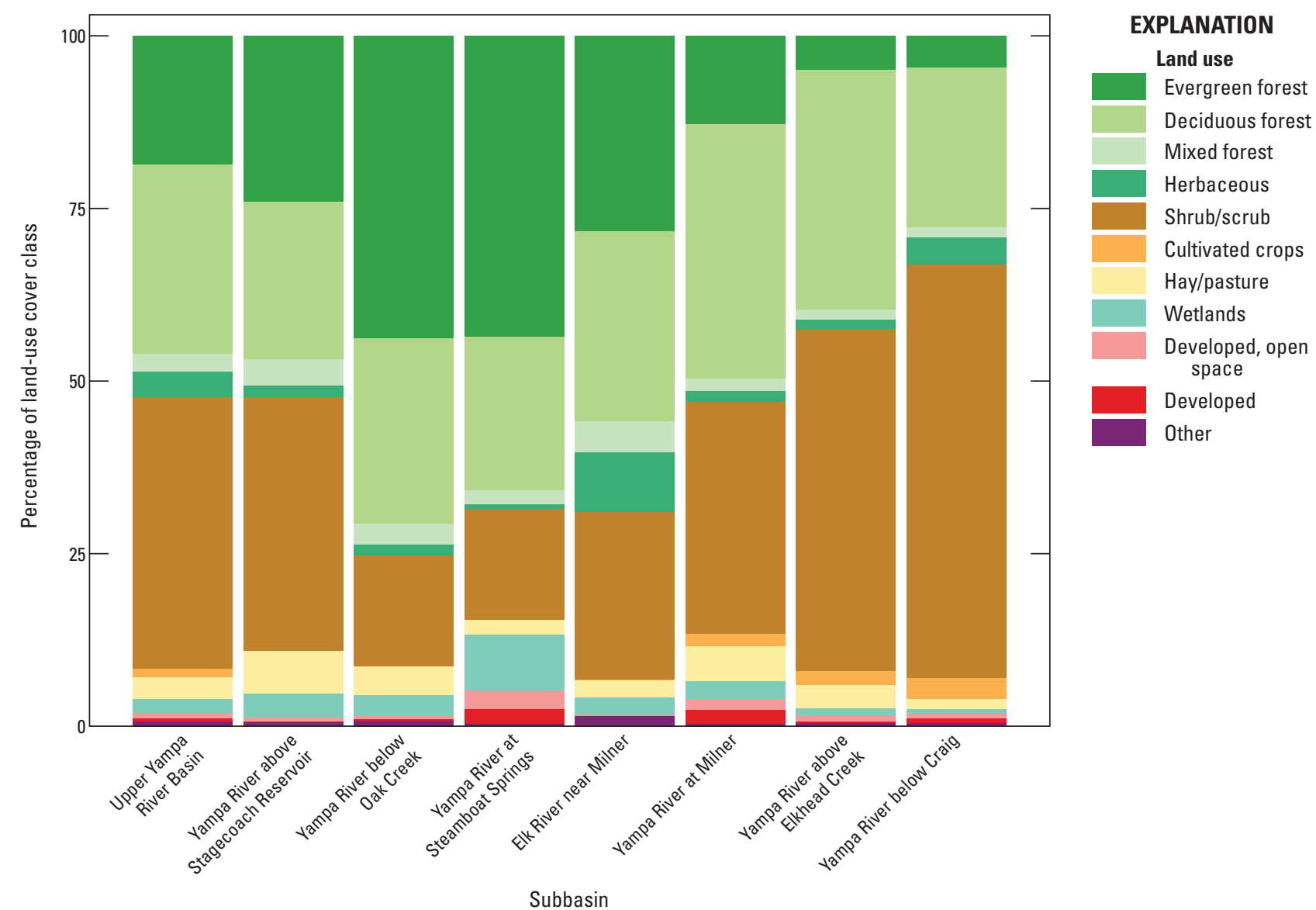

Figure 18. Graph showing percentage of land-use cover classes in the Upper Yampa River Basin, Colorado, and its subbasins in 2016 (from Multi-Resolution Land Characteristics Consortium, 2020). (“Other” includes Barren, Open Water, and Snow/lce classes)

North America predominately associated with changes in snowmelt runoff and temperatures. The seasonality of suspended sediment, nitrogen, and phosphorus concentrations and loads across sites indicates that most of these constituents enter the rivers during spring runoff; thus, managing inputs during these events may decrease the potential for exceedances of the CDPHE standards in the future. Geological features and land use were the most likely factors contributing to high concentrations and yields of suspended sediment and nutrients and upward trends at some sites. Linking changes in streamflow and water quality to land cover and changes in land use was limited by the lack of available data to characterize these factors on a subbasin scale.

The observed changes in streamflow at main-stem and tributary sites likely reflect the combined effect of changes in precipitation and increases in temperature related to climate change and increased water use. In this report, the long-term trends in streamflow at Yampa River at Steamboat Springs from WY 1910 to WY 2018 correspond to documented changes happening in the Colorado River Basin, including reductions in annual streamflow especially during spring and summer periods (fig. 5; Miller and Piechota, 2008) and changes in the timing of peak streamflow (fig. 6; Clow, 2010). For example, variability in streamflow in the Colorado River Basin is largely controlled by the amount of cool season precipitation and spring and summer air temperatures (Woodhouse and others, 2016). Thus, water supply in the Colorado River Basin is increasingly affected by warming temperatures that have decreased winter snowpack (Mote and others, 2018), caused earlier snowmelt runoff (Clow, 2010), and increased evaporation losses in the basin (Udall and Overpeck, 2017). The basin-wide comparison of trends in streamflow during a shorter time period, from WY 1992 to WY 2018, showed significant decreases in streamflow during winter months across main-stem and some tributary sites (fig. 4). In addition to possible contributions from changes in consumptive use and reservoir management, this time period coincides with one of the hottest drought periods in the Colorado River Basin, where annual mean streamflow was 19 percent below that of the 20th century (Udall and Overpeck, 2017). Projected hydrographs based on planning scenarios that incorporate the effects expected from climate change predict 
Table 8. Change in forest and development land-cover classes in the Upper Yampa River Basin, Colorado (CO), and subbasins from 2001 to 2016.

[Land-cover data from National Land Cover Database (Multi-Resolution Land Characteristics Consortium, 2020). mi², square mile; UYRB, Upper Yampa River Basin]

\begin{tabular}{|c|c|c|c|c|c|c|c|c|c|c|c|}
\hline \multirow{2}{*}{ Location } & \multirow{2}{*}{$\begin{array}{l}\text { Total area } \\
\left(\mathrm{mi}^{2}\right)\end{array}$} & \multicolumn{2}{|c|}{ Evergreen forest } & \multicolumn{2}{|c|}{ Deciduous forest } & \multicolumn{2}{|c|}{ Mixed forest } & \multicolumn{2}{|c|}{ Developed } & \multicolumn{2}{|c|}{$\begin{array}{l}\text { Developed, open } \\
\text { space }\end{array}$} \\
\hline & & $\begin{array}{l}\text { Change in } \\
\text { area }\left(\mathrm{mi}^{2}\right)\end{array}$ & $\begin{array}{l}\text { Percent } \\
\text { change }\end{array}$ & $\begin{array}{l}\text { Change in } \\
\text { area }\left(\mathrm{mi}^{2}\right)\end{array}$ & $\begin{array}{l}\text { Percent } \\
\text { change }\end{array}$ & $\begin{array}{l}\text { Change in } \\
\text { area }\left(\mathrm{mi}^{2}\right)\end{array}$ & $\begin{array}{l}\text { Percent } \\
\text { change }\end{array}$ & $\begin{array}{l}\text { Change in } \\
\text { area }\left(\mathrm{mi}^{2}\right)\end{array}$ & $\begin{array}{l}\text { Percent } \\
\text { change }\end{array}$ & $\begin{array}{l}\text { Change in } \\
\text { area }\left(\mathrm{mi}^{2}\right)\end{array}$ & $\begin{array}{l}\text { Percent } \\
\text { change }\end{array}$ \\
\hline UYRB & 2,100 & -26 & -1.2 & -2.7 & -0.13 & -0.41 & -0.019 & 0.79 & 0.037 & 0.38 & 0.018 \\
\hline \multicolumn{12}{|c|}{ Subbasin } \\
\hline $\begin{array}{l}\text { Yampa River above } \\
\text { Stagecoach } \\
\text { Reservoir }\end{array}$ & 210 & -0.61 & -0.29 & -0.11 & -0.052 & 0.11 & 0.053 & 0.00035 & 0.00017 & 0.0024 & 0.0012 \\
\hline $\begin{array}{l}\text { Yampa River below } \\
\text { Oak Creek near } \\
\text { Steamboat Springs }\end{array}$ & 260 & -4.2 & -1.6 & 0.062 & 0.024 & 0.016 & 0.0061 & 0.0014 & 0.00054 & -0.0014 & -0.00054 \\
\hline $\begin{array}{l}\text { Yampa River at } \\
\text { Steamboat Springs }\end{array}$ & 100 & -0.14 & -0.13 & -0.023 & -0.022 & 0.00035 & 0.00034 & 0.39 & 0.38 & 0.19 & 0.18 \\
\hline Elk River near Milner & 460 & -21 & -4.6 & -1.4 & -0.29 & -0.77 & -0.17 & 0 & 0 & 0 & 0 \\
\hline $\begin{array}{l}\text { Yampa River at } \\
\text { Milner }\end{array}$ & 85 & -0.15 & -0.18 & -0.035 & -0.041 & 0.030 & 0.035 & 0.13 & 0.15 & 0.071 & 0.084 \\
\hline $\begin{array}{l}\text { Yampa River above } \\
\text { Elkhead Creek near } \\
\text { Hayden }\end{array}$ & 460 & 0.0052 & 0.0011 & -0.50 & -0.11 & 0.024 & 0.0053 & 0.066 & 0.015 & 0.070 & 0.015 \\
\hline $\begin{array}{l}\text { Yampa River below } \\
\text { Craig }\end{array}$ & 560 & 0.2 & 0.035 & -0.73 & -0.13 & 0.18 & 0.032 & 0.21 & 0.037 & 0.055 & 0.0098 \\
\hline
\end{tabular}

8-11 percent reductions in annual streamflow by 2030 at the Yampa River at Steamboat Springs site (Colorado Department of Natural Resources, 2019).

Concentrations of simulated water-quality constituents exhibited similarities in seasonal variations at most sites, indicating that factors controlling input of constituents to streams in the UYRB may be similar across sites. At main-stem Yampa River sites downstream from Stagecoach Reservoir, suspended sediment, Kjeldahl nitrogen, and total phosphorus concentrations were typically highest in spring (March, April, and May) (figs. 7, 8, and 11). High concentrations of constituents that bind to particulate matter may enter streams during the early snowmelt runoff period as material washed off the land surface drains into streams (Hirsch, 2011). Median concentrations of Kjeldahl nitrogen and total phosphorus were less than CDPHE interim standards at all sites (table 5); however, managing inputs during snowmelt runoff may decrease the potential for exceedances of the CDPHE standards in the future. Compared to other sites, Yampa River at Milner had an earlier peak of total phosphorus concentrations in February and March (fig. 11); the peak corresponded with higher discrete concentrations of orthophosphate (fig. 12), indicating that this site may have different or additional sources of phosphorus from upstream inputs. One notable difference in land use is the larger portion of developed lands upstream (fig. 18) in and around the city of
Steamboat Springs. Seasonal increases in nutrients from these urban areas, such as wastewater treatment plant discharge, may be influencing the seasonal patterns.

Yampa River at Milner and Yampa River above Elkhead Creek had the highest net yields of suspended sediment, Kjeldahl nitrogen, and total phosphorus in the UYRB (fig. 13) and are likely influenced by urban development and local geological features. Although the Yampa River at Milner subbasin is the smallest in the UYRB, it includes much of the Steamboat Springs area. The subbasin is also underlain by Mancos Shale (fig. 2), a Late Cretaceous marine deposit that can contain nitrogen sources and is highly erodible especially following surface disturbance (Thomas and others, 2019; Fick and others, 2020). Most of the Yampa River above Elkhead Creek subbasin is underlain by the Yampa coal field (fig. 2), which has high phosphorus content (30 times greater than the mean value for Cretaceous-age coal) because of ash deposits (Affolter, 2000).

Disturbances to the land surface in Yampa River at Milner and Yampa River above Elkhead Creek subbasins, including grazing, construction of urban areas, and increases in mining or harvesting of timber, could exacerbate contributions of sediment and nutrients to the river. Higher water velocity, channel incision, and loss of vegetation along streambanks can be a large source of suspended sediment in basins (Kenney and others, 2009). One of the major anthropogenic sources of suspended 
sediment is irrigation of agricultural land, particularly when the land is derived from sedimentary rocks (Kenney and others, 2009). The relatively small yields of total phosphorus from the Yampa River at Steamboat Springs subbasin compared to other subbasins indicate that the influence of urban development may not be detected until farther downstream, or that land uses other than urban development may contribute more to phosphorus loading across the UYRB. Also, the underlying geology associated with the Yampa River at Steamboat subbasin is crystalline metamorphic and igneous rocks (Bauch and others, 2012) that do not contribute phosphorus to the system through rapid erosion. Collection of land-use data at a higher spatial resolution could provide additional information on load sources.

The upward trends in Kjeldahl nitrogen and total phosphorus concentrations and loads at Yampa River at Steamboat Springs may reflect changes in land use and streamflow regime (fig. 14). The weighted regression method used for this site allows separate analysis of concentration and load trends, which can provide insight into when changes occur. As mean loads are the product of concentration and discharge integrated over time, the days of the highest streamflow can strongly influence load trends. Larger changes in loads than in concentrations can indicate that much of the change is occurring during high streamflow periods (Hirsch and De Cicco, 2015). Percentage changes in Kjeldahl nitrogen and total phosphorus loads were twice the concurrent changes in concentrations (table 7). Therefore, changes in the amounts of nitrogen and phosphorus entering the river during high streamflow periods likely contribute to the observed trends. The downward trends in streamflow during spring months at this site (fig. 5) may lead to decreased dilution of nutrients and result in higher concentrations, a response that is commonly observed during droughts (Mosley, 2015). Changes in upstream inputs from dominant land covers, including forested and developed land areas, also likely contribute to upward trends at Yampa River at Steamboat Springs (figs. 17 and 18). To investigate causes of upward trends in Kjeldahl nitrogen and total phosphorus concentrations and loads, monitoring for additional variables is needed to improve the predictive ability of regression models.

Geological features and land use upstream from Stagecoach Reservoir likely contribute to the increasing frequency of cyanobacterial blooms in the reservoir. Concerns of cyanobacterial blooms and elevated phosphorus concentrations have been associated with Stagecoach Reservoir since its completion (Bureau of Reclamation, 1986). Stagecoach Reservoir overlies sandstones and shales (fig. 2), which contribute dissolved materials to surface water (Terziotti and others, 2010); thus, it is likely that geological features contribute to the elevated levels of phosphorus. Across all sites examined, annual median and median annual concentrations of suspended sediment were highest at Yampa River above Stagecoach Reservoir (table 5). No trends in phosphorus concentrations were observed at this site, but existing phosphorus concentrations in combination with other changes, such as increasing temperatures, can further promote algae blooms (Paerl and Otten, 2013). Land use in the
Yampa River above Stagecoach Reservoir subbasin contains the highest percentage of hay fields and pastureland in the UYRB (figs. 17 and 18). Grazing practices may exacerbate soil erosion (Duniway and others, 2019). Fertilizer application may also contribute to dissolved phosphorus levels in the rivers in summer months when conditions are most favorable for algae blooms (Van Meter and others, 2020). Maximum concentrations of Kjeldahl nitrogen, total nitrogen, total phosphorus, and orthophosphate occur slightly later at Yampa River above Stagecoach Reservoir than other sites (in May, June, and July), indicating that different factors control nutrient inputs at this site (figs. 9, 11, and 12).

Although regression models can support a conceptual understanding of what factors (for example, streamflow) influence variability in concentrations and loads, the models may generate poor estimates when limited explanatory variables are available, and when not all sources and processes are well defined by available sampling data. The utility of some of the models used to make estimates of suspended sediment, Kjeldahl nitrogen, and total phosphorus concentrations, loads, and trends were more limited at some sites due to limited sample data or explanatory variables (tables 3 and 4). For example, phosphorus is generally transported in streams sorbed to sediment particles and thus behaves similarly to suspended sediment. In basins where total nitrogen and total phosphorus are primarily in the particulate form, information from turbidity datasets may provide improved estimates of nutrient loading than the use of streamflow data alone (Jones and others, 2011; Lessels and Bishop, 2013). Additionally, variations in nutrient concentrations may not be accurately captured by quarterly sampling. Quarterly sampling provides a snapshot of seasonal variation in water-quality constituents but does not necessarily capture the influence of other factors including storm events, groundwater interactions, and land-use related activities. At sites likely to have more urban influence, including Yampa River at Steamboat Springs and Yampa River at Milner, more targeted sampling to capture urban runoff during storm events, wastewater treatment plant discharge, and inputs from groundwater sources, may help to improve model estimates in the future. Similarly, a large proportion of streamflow data was estimated at Yampa River below Oak Creek and Yampa River at Milner (see the "Extension of Streamflow Record" section), thus, errors in the estimated hydrographs will be propagated into concentration, load, and yield calculations. Continuous streamflow records at these sites may reduce uncertainty at these sites. The lack of trends in suspended sediment, Kjeldahl nitrogen, and total phosphorus concentrations at sites upstream from Steamboat Springs (Yampa River at Oak Creek and Yampa River above Stagecoach Reservoir) does not necessarily mean that conditions at these sites do not contribute to the upward trends observed at downstream sites. Limitations in available data and trend analysis techniques at these upstream sites, which may be less sensitive to trends exhibiting seasonality or nonlinear trend slopes, can prevent identification of significant trends (Hirsch and De Cicco, 2015). Continued monitoring may improve the ability to detect 
currently unidentified trends in these areas by providing data that better meet regression assumptions and requirements and allow for additional trend assessments.

An assessment of the influence of land use on water quality and quantity could not be fully explored in this report because of limited land-use data. The accuracy of some landcover classifications from the National Land Cover Database (Multi-Resolution Land Characteristics Consortium, 2020) only permitted analysis of land-use changes for development and forest classes. Other studies have found changes in land management and (or) land use and cover to be the major driver of changes in water quality (see references in Murphy and Sprague, 2019). Thus, any future studies would benefit by incorporating data that represents characteristics, which may or may not have changed over time, including land use and agricultural practices, on a finer spatial scale.

\section{Summary}

The Yampa River, in the Upper Colorado River Basin in northwestern Colorado, is the largest mostly free-flowing river in the Colorado River system. Because of limited reservoir storage, the river is known for its largely unaltered natural condition and biological diversity and is a valued multiuse resource in the Upper Yampa River Basin (UYRB). There is a growing need to understand potential changes in the quantity and quality of water resources as the basin is undergoing increasing land and water development to support growing municipal, industrial, and recreational needs. In 2019, the U.S. Geological Survey (USGS), in cooperation with local stakeholders in the water community, began a study to characterize streamflow and surface-water quality at selected sites in the UYRB study area. The cooperating stakeholders are the Upper Yampa River Watershed Group, Upper Yampa Water Conservancy District, Colorado Water Conservation Board, Yampa-White-Green Basin Roundtable, Mount Werner Water and Sanitation District, Routt County, and the city of Steamboat Springs. The assessment of streamflow and surface-water quality in this study is designed to characterize changes in streamflow and selected water-quality constituents in the UYRB as they relate to regulatory standards and toxicity concerns, and to help provide a better understanding of how major factors, including land use and geological features, may contribute to changes in hydrology in the UYRB study area. This report (1) describes seasonal variation and temporal trends in streamflow, suspended sediment, and nutrient concentrations and loads; (2) provides comparisons of nutrient concentrations to State of Colorado interim concentrations for water-quality standards; (3) identifies subbasins with higher suspended sediment and nutrient yields; (4) summarizes water temperature, water-quality, and algal data for Stagecoach Reservoir; and (5) assesses land-cover changes in the basin.
The UYRB drains approximately 2,100 square miles of the Yampa River Basin west of the Continental Divide in northwestern Colorado. Much of the basin is underlain by sedimentary rocks of Cretaceous age, including sandstones, shales, and major coal beds. Streamflow in the UYRB is dominated by snowmelt runoff, with flows increasing in April, peaking in May and June, and decreasing in July. Stagecoach Reservoir, upstream from the USGS site Yampa River at Steamboat Springs, Colorado, is the largest storage facility in the UYRB with a total capacity of approximately 36,500 acre-feet. There are no main-stem reservoirs downstream from the city of Steamboat Springs, Colo.

Streamflow and water-quality data used in this report were collected by the USGS. Water-quality data include suspended sediment, Kjeldahl nitrogen, total nitrogen, total phosphorus, orthophosphate, temperature, dissolved oxygen, planktonic algal densities, and toxin concentrations for streams and Stagecoach Reservoir. All USGS continuous streamflow data and discrete water-quality data were collected, analyzed, and approved in accordance with USGS standards.

Since 1992, when the Stagecoach Reservoir was completed, through 2018, all main-stem sites had significant downward trends in one or more streamflow statistics during winter months. Downward trends were found across most months at Yampa River above Stagecoach Reservoir, Colo., with significant downward trends in mean and 7-day minimum streamflow statistics during January and February. Annual downward trends in 7-day minimum streamflows of 15 percent per decade, or 35 percent over the 27-year period of analysis, were also observed. At the site directly downstream from Stagecoach Reservoir, downward trends in all three streamflow statistics were found from September through February, ranging from 11 to 23 percent per decade, or 27 to 51 percent overall. Downward trends in streamflow at Yampa River at Steamboat Springs, Colo., Yampa River above Elkhead Creek near Hayden, Colo., and Yampa River below Craig, Colo., had similar magnitudes during the same time period.

Trends in streamflow at tributary sites likely correspond to changes in reservoir management; at sites with no upstream flow impoundments, changes likely correspond to irrigation diversions and climate change related factors. At Fish Creek at Upper Station near Steamboat Springs, downward trends in mean and 7-day minimum streamflows of 36 percent and 31 percent per decade or 70 percent and 64 percent overall, were found in July, respectively. Significant upward trends in 7-day minimum streamflows ranging from 41 to 67 percent per decade, or 150 to 302 percent overall, occurred in August, September, and October from CY 1992 to CY 2018. These changes likely correspond to changes in water use at Fish Creek Reservoir, the primary source of municipal water supplies for Steamboat Springs. Like the main-stem sites, Elkhead Creek near Hayden also had significant downward trends in all three streamflow statistics during winter months, November through February, ranging from 27 to 44 percent per decade, or 58 to 79 percent overall. Elkhead Creek near Hayden is upstream 
from Elkhead Reservoir, thus trends at this site may be more indicative of changes in climatic factors or changes in water management, including diversion for irrigation.

Streamflow trends examined across a longer time period, from 1910 to 2018, at Yampa River at Steamboat Springs correspond to observed changes in streamflow documented across western North America and the Colorado River Basin. Downward trends were found during spring and summer months and annually for maximum and mean streamflows. Significant downward trends in daily mean streamflows of 2 percent per decade, or 22 percent across the 109-year period of analysis, were found in April. A fairly significant ( $p$-value =0.06) downward trend in the deviation from mean peak streamflow date was found, indicating that peak streamflow is occurring earlier at Yampa River at Steamboat Springs.

At sites downstream from Stagecoach Reservoir, estimated daily concentrations of suspended sediment, Kjeldahl nitrogen, and total phosphorus concentrations were typically highest in spring (March, April, and May). Highest concentrations occurred slightly later at Yampa River above Stagecoach Reservoir, Colo., than the other sites in May, June, and July, indicating that different factors control nutrient inputs at this site. Yampa River at Milner, Colo., had an earlier peak of total phosphorus concentrations in February and March, corresponding with higher discrete concentrations of orthophosphate, indicating that this site may have different or additional sources of phosphorus from upstream inputs, including the wastewater treatment plant discharge for the city of Steamboat Springs. Median concentrations of Kjeldahl nitrogen and total phosphorus were less than Colorado Department of Public Health and Environment interim standards at all sites. Managing inputs during the identified periods with highest concentrations may decrease the potential for exceedances of the standards in the future.

Yampa River at Milner, Colo., and Yampa River above Elkhead Creek near Hayden, Colo., had the highest net yields based on a normalized hydrograph of suspended sediment, Kjeldahl nitrogen, and total phosphorus in the UYRB. Both subbasins are underlain by highly erodible Cretaceous shales, and Yampa River at Milner, Colo., has urban influence from the city of Steamboat Springs.

A highly likely upward trend in the streamflow-normalized Kjeldahl nitrogen concentration and load from 1999 to 2018 was indicated at Yampa River at Steamboat Springs. The Kjeldahl nitrogen concentration likely increased by 10 percent or 0.035 milligram per liter ( $\mathrm{mg} / \mathrm{L})$, and load also likely increased by 22 percent, or 26 tons across the time period. Total phosphorus concentration likely increased by 20 percent or $0.0081 \mathrm{mg} / \mathrm{L}$, and loads also likely increased by 241 percent or 6.2 tons across the time period. Downward trends in streamflow and changes in upstream inputs from dominant land covers, including forested and developed land areas, may contribute to these trends. No other trends were detected in the basin.
On multiple sampling events at Stagecoach Reservoir, the physical and chemical factors indicated conditions conducive to cyanobacterial blooms. Surface-water temperatures exceeded 20 degrees Celsius on multiple sampling days. Total phosphorus concentrations in surface waters exceeded the interim Colorado Department of Public Health and Environment water-quality standard of $0.025 \mathrm{mg} / \mathrm{L}$ in August and September of both 2017 and 2018, whereas total nitrogen exceeded the interim standard of $0.426 \mathrm{mg} / \mathrm{L}$ on every sampling date. The total nitrogen-total phosphorous ratios (TN:TP) in samples collected at 3 feet ranged from 15 to 31 .

Cyanobacteria had the highest cell densities compared to other planktonic algae in samples collected in Stagecoach Reservoir and total cyanobacterial cell densities exceeded the World Health Organization guideline values for a moderate probability of adverse health effects $(100,000$ cells per milliliter) in July and August of 2017. The cyanotoxin microcystin was detected in Stagecoach Reservoir in September 2018, but the total microcystin concentration of 0.26 microgram per liter was much less than the U.S. Environmental Protection Agency recreational advisory level of 4 micrograms per liter for microcystins. Two other types of cyanotoxins, total saxitoxins and total cylindrospermopsins, were also measured and were below detection limits on all dates.

The dominant land cover in the UYRB in 2016 was forest, which accounted for 49 percent of total land area. Other prominent land covers included shrub/scrub (39 percent), herbaceous (3.7 percent), and hay/pasture (3 percent). Development, including open space, accounted for approximately 1.5 percent of land area in the UYRB. Developed land was greatest in the Yampa River at Steamboat Springs subbasin, where approximately 5 percent of the subbasin was developed. From 2001 to 2016, evergreen forest cover decreased by 26 square miles, representing 1.2 percent of the total basin area. Subbasins with the highest evergreen forest loss include Elk River near Milner (21 square miles or 4.6 percent of the relative area of the subbasin), and Yampa River below Oak Creek (4.2 square miles or 1.6 percent of relative area of the subbasin). Developed land area, which includes high-, medium-, and low-density land development, increased by 0.79 square mile across the UYRB, with the largest increase of 0.39 square mile in the Yampa River at Steamboat Springs subbasin.

Addressing the information needs identified by this study would aid in understanding water quality in the UYRB. Most of the suspended sediment and nutrient data used in this report are collected quarterly. Increased frequency of sampling, or more targeted sampling to capture urban runoff during storm events, wastewater treatment plant discharge, and inputs from groundwater sources, may help to improve understanding of the sources of these constituents. Land-use and land-cover data reflecting subbasin-scale changes would assist in a better understanding of how changes in these factors contribute to streamflow and water-quality trends. 


\section{Acknowledgments}

The author thanks several U.S. Geological Survey staff for assistance with the report. Helpful discussions with Ken Leib and Robert Hirsch enhanced the understanding and interpretation of regression methods and streamflow trend analysis. The report was improved by review comments from Rodney Richards and Nancy Bauch.

\section{References Cited}

AECOM and Colorado Water Conservation Board, 2009, Yampa River Basin information: Denver, Colo., Colorado Water Conservation Board, prepared by AECOM, 57 p., accessed June 18, 2018, at https://dnrweblink.state.co.us/ $\mathrm{cwcb} /$ ElectronicFile. aspx .docid $=146636 \& \mathrm{dbid}=0$.

Affolter, R.H., 2000, Quality characterization of Cretaceous coal from the Colorado Plateau coal assessment area, chap. $\mathrm{G}$ of Kirschbaum, M.A., Roberts, L.N.R., and Biewick, L.R.H., eds., Geologic assessment of coal in the Colorado Plateau - Arizona, Colorado, New Mexico, and Utah: U.S. Geological Survey Professional Paper 1625-B, p. G1-G136.

Bauch, N.J., Moore, J.L., Schaffrath, K.R., and Dupree, J.A., 2012, Water-quality assessment and macroinvertebrate data for the Upper Yampa River watershed, Colorado, 1975 through 2009: U.S. Geological Survey Scientific Investigations Report 2012-5214, 129 p., accessed June 5, 2019, at https://doi.org/10.3133/sir20125214.

Bennett, K.E., Cannon, A.J., and Hinzman, L., 2015, Historical trends and extremes in boreal Alaska river basins: Journal of Hydrology (Amsterdam), v. 527, p. 590-607.

Bureau of Reclamation, 1986, Stagecoach Reservoir ProjectColorado, final environmental impact statement: U.S. Department of the Interior, 358 p., accessed February 26, 2020, at https://books.google.com/books?id=eR IzAQAAMAAJ\&printsec $=$ frontcover\&source $=$ gbs_ge summary_r\&cad $=0 \# \mathrm{v}=$ onepage $\& \mathrm{q} \& \mathrm{f}=$ false.

Chorus, I., and Bartram, J., eds., 1999, Toxic cyanobacteria in water-A guide to their public health consequences, monitoring and management: London, Spon Press, 400 p.

Clow, D.W., 2010, Changes in the timing of snowmelt and streamflow in Colorado-A response to recent warming: Journal of Climate, v. 23, no. 9, p. 2293-2306.

Cohn, T.A., 2005, Estimating contaminant loads in riversAn application of adjusted maximum likelihood to type 1 censored data: Water Resources Research, v. 41, no713 p., accessed November 15, 2018, at https://doi.org/10.1029/ 2004WR003833.
Cohn, T.A., Caulder, D.L., Gilroy, E.J., Zynjuk, L.D., and Summers, R.M., 1992, The validity of a simple statistical model for estimating fluvial constituent loads-An empirical study involving nutrient loads entering Chesapeake Bay: Water Resources Research, v. 28, no. 9, p. 2353-2363.

Colorado Department of Natural Resources, 2019, Technical update to water plan-Yampa_SWSIResults.xlsx: Colorado Department of Natural Resources website, accessed October 2019 at https://dnrftp.state.co.us/\#/CWCB/ Technical $\% 20$ Update $\% 20$ to $\% 20$ Water $\% 20$ Plan/3.\%20 Modeling\%20Data/4.\%20Water\%20Supply\%20and\%20 Gap/Results.

Colorado Department of Public Health and Environment [CDPHE], 2017, Water Quality Control Commission, Regulation No. 31-The Basic Standards and Methodologies for Surface Water: Colorado Water Quality Control Commission, 230 p., accessed September 3, 2019, at https://www.colorado.gov/pacific/cdphe/clean-waternutrients.

Colorado State Demography Office, 2018, Jobs by sector (NAICS): Colorado Department of Local Affairs, Colorado State Demography Office website, accessed February 15, 2020, at https://demography.dola.colorado.gov/economylabor-force/data/jobs-by-sector.

Colorado State Forest Service, 2019, 2018 report on the health of Colorado's forests-Special section-Protecting our communities: Colorado State Forest Service, 28 p., accessed June 3, 2020, at https://csfs.colostate.edu/media/sites/22/ 2019/03/FINAL-307714_ForestRpt-2018-www.pdf.

Colorado State Forest Service, 2020, 2019 forest health report story map: Colorado State Forest Service website, accessed June 3, 2020, at https://csfs.colostate.edu/forestmanagement/2019-forest-health-report-story-map/.

Corbel, S., Mougin, C., and Bouaïcha, N., 2014, Cyanobacterial toxins-Modes of actions, fate in aquatic and soil ecosystems, phytotoxicity and bioaccumulation in agricultural crops: Chemosphere, v. 96, p. 1-15.

Day, N.K., 2021, Input and output data from streamflow and water-quality regression models used to characterize streamflow and water-quality conditions in the Upper Yampa River Basin, Colorado, from 1992 to 2018: U.S. Geological Survey data release, https://doi.org/10.5066/ P9L7S3NQ.

Dieter, C.A., Maupin, M.A., Caldwell, R.R., Harris, M.A., Ivahnenko, T.I., Lovelace, J.K., Barber, N.L., and Linsey, K.S., 2018, Estimated use of water in the United States in 2015: U.S. Geological Survey Circular 1441, 65 p., accessed February 4, 2020, at https://doi.org/10.3133/ cir1441. [Supersedes USGS Open-File Report 2017-1131.] 
Downing, J.A., Watson, S.B., and McCauley, E., 2001, Predicting cyanobacteria dominance in lakes: Canadian Journal of Fisheries and Aquatic Sciences, v. 58, no. 10, p. 1905-1908.

Duniway, M.C., Pfennigwerth, A.A., Fick, S.E., Nauman, T.W., Belnap, J., and Barger, N.N., 2019, Wind erosion and dust from US drylands-A review of causes, consequences, and solutions in a changing world: Ecosphere, v. 10, n3article e02650, 28 p., accessed June 18, 2020, at https://doi.org/ $10.1002 /$ ecs 2.2650 .

Esri, 2018, ArcGIS Desktop ver. 10.7.1: Esri website, accessed December 17, 2018, at https://desktop.arcgis.com/ en/arcmap/.

Fick, S.E., Belnap, J., and Duniway, M.C., 2020, Grazinginduced changes to biological soil crust cover mediate hillslope erosion in long-term exclosure experiment: Rangeland Ecology and Management, v. 73, no. 1, p. 61-72.

Forsberg, C., 1979, Die physiologischen Grundlagen der Gewässer-Eutrophierung: Wasser Abwasser Forsch, v. 12, p. $40-45$.

Halliday, L., 2016, Upper Yampa River Watershed PlanProtecting and managing long term health, Upper Yampa River Watershed Plan Executive Summary May 2016: Steamboat Springs, Colo., Upper Yampa Watershed Group, prepared by Environmental Solutions Unltd, LLC, 87 p.

Helsel, D.R., Hirsch, R.M., Ryberg, K.R., Archfield, S.A., and Gilroy, E.J., 2020, Statistical methods in water resources: U.S. Geological Survey Techniques and Methods, book 4, chapter A3, 458 p., accessed July 5, 2020, at https://doi.org/ 10.3133/tm4a3. [Supersedes USGS Techniques of WaterResources Investigations, book 4, chapter A3, version 1.1.]

Hem, J.D., 1985, Study and interpretation of the chemical characteristics of natural water, $3 \mathrm{~d}$. ed.: U.S. Geological Survey Water-Supply Paper 2254, accessed February 2020 at https://pubs.usgs.gov/wsp/wsp2254/.

High Plains Regional Climate Center, 2020, Monthly Summarized Data: Lincoln, Nebr., High Plains Regional Climate Center web page, accessed January 2020 at http://climod.unl.edu/.

Hirsch, R.M., 1979, An evaluation of some record reconstruction techniques: Water Resources Research, v. 15, no. 6, p. 1781-1790.

Hirsch, R.M., 2011, A perspective on nonstationary and water management: Journal of the American Water Resources Association, v. 47, no. 3, p. 436-446.

Hirsch, R.M., Alexander, R.B., and Smith, R.A., 1991, Selection of methods for detection and estimation of trends in water quality data: Water Resources Research, v. 27, no. 5 , p. 803-813.
Hirsch, R.M., Archfield, S.A., and De Cicco, L.A., 2015, A bootstrap method for estimating uncertainty of water quality trends: Environmental Modelling \& Software, v. 73, p. $148-166$.

Hirsch, R.M., and De Cicco, L.A., 2015, User guide to Exploration and Graphics for RivEr Trends (EGRET) and dataRetrieval - R packages for hydrologic data (version 2.0, February 2015): U.S. Geological Survey Techniques and Methods, book 4, chapter A10, 93 p., accessed January 1, 2018, at https://doi.org/10.3133/tm4A10.

Jones, A., Stevens, D., Horsburgh, J., and Mesner, N., 2011, Surrogate measures for providing high frequency estimates of total suspended solids and total phosphorus concentrations: Journal of the American Water Resources Association, v. 47, no. 2, p. 239-253.

Kenney, T.A., Gerner, S.J., Buto, S.G., and Spangler, L.E., 2009, Spatially referenced statistical assessment of dissolved-solids load sources and transport in streams of the Upper Colorado River Basin: U.S. Geological Survey Scientific Investigations Report 2009-5007, 50 p., accessed June 2020 at https://pubs.usgs.gov/sir/2009/5007.

Kirschbaum, M.A., and Biewick, L.R.H., 2000, A summary of the coal deposits in the Colorado Plateau-Arizona, Colorado, New Mexico, and Utah, chap. B of Kirschbaum, M.A., Roberts, L.N.R., and Biewick, L.R.H., eds., Geologic assessment of coal in the Colorado Plateau-Arizona, Colorado, New Mexico, and Utah: U.S. Geological Survey Professional Paper 1625-B, p. B1-B99, accessed September 3, 2020, at https://doi.org/10.3133/pp1625B.

Lessels, J.S., and Bishop, T.F.A., 2013, Estimating water quality using linear mixed models with stream discharge and turbidity: Journal of Hydrology (Amsterdam), v. 498, p. 13-22.

Lopez, C.B., Jewett, E.B., Dortch, Q., Walton, B.T., and Hudnell, H.K., 2008, Scientific assessment of freshwater harmful algal blooms: Washington, D.C., Joint Subcommittee on Ocean Science and Technology, Interagency Working Group on Harmful Algal Blooms, Hypoxia and Human Health, 65 p., accessed June 2020 at https://www.whoi.edu/fileserver.do?id=41023\&pt= $10 \& p=19132$.

Lorenz, D.L., Robertson, D.M., Hall, D.W., and Saad, D.A., 2009, Trends in streamflow and nutrient and suspended-sediment concentrations and loads in the Upper Mississippi, Ohio, Red, and Great Lakes River Basins, 1975-2004: U.S. Geological Survey Scientific Investigations Report 2008-5213, 81 p., accessed June 3, 2020, at https://doi.org/10.3133/ sir20085213. 
Lorenz, D.L., Runkel, R.L., and De Cicco, L., 2015, rloadest-USGS water science R functions for LOAD ESTimation of constituents in rivers and streams, $\mathrm{v}$ 0.4.1: GitHub, Inc. web page, accessed September 6, 2018, at https://github.com/USGS-R/rloadest.

Mikkelson, K.M., Dickenson, E.R.V., Maxwell, R.M., McCray, J.E., and Sharp, J.O., 2013, Water-quality impacts from climate-induced forest die-off: Nature Climate Change, v. 3, no. 3, p. 218-222.

Miller, W.P., and Piechota, T.C., 2008, Regional analysis of trend and step changes observed in hydroclimatic variables around the Colorado River basin: Journal of Hydrometeorology, v. 9, no. 5, p. 1020-1034.

Monitoring Trends in Burn Severity, 2020, Interactive viewer-Monitoring trends in burn severity: Monitoring Trends in Burn Severity website, accessed January 20, 2020, at https://www.mtbs.gov/viewer/index.html.

Monteith, D.T., Stoddard, J.L., Evans, C.D., de Wit, H.A., Forsius, M., Høgåsen, T., Wilander, A., Skjelkvåle, B.L., Jeffries, D.S., Vuorenmaa, J., Keller, B., Kopácek, J., and Vesely, J., 2007, Dissolved organic carbon trends resulting from changes in atmospheric deposition chemistry: Nature, v. 450 , no. 7169 , p. $537-540$.

Mosley, L.M., 2015, Drought impacts on the water quality of freshwater systems - Review and integration: Earth-Science Reviews, v. 140, p. 203-214.

Mote, P.W., Li, S., Lettenmaier, D.P., Xiao, M., and Engel, R., 2018, Dramatic declines in snowpack in the western US: npj Climate and Atmospheric Science, v. 1, article 2, 6 p., accessed July 7, 2020, at https://doi.org/10.1038/s41612018-0012-1.

Mueller, D.K., Hamilton, P.A., Helsel, D.R., Hitt, K.J., and Ruddy, B.C., 1995, Nutrients in groundwater and surface water of the United States - An analysis of data through 1992: U.S. Geological Survey Water-Resources Investigations Report 95-4031, $74 \mathrm{p}$.

Multi-Resolution Land Characteristics Consortium, 2020, National Land Cover Database (NLCD) 2016: MultiResolution Land Characteristics Consortium website, accessed June 3, 2020, at https://www.mrlc.gov/nationalland-cover-database-nlcd-2016.

Murphy, J., and Sprague, L., 2019, Water-quality trends in US rivers-Exploring effects from streamflow trends and changes in watershed management: The Science of the Total Environment, v. 656, p. 645-658.
Oblinger Childress, C.J., Foreman, W.T., Connor, B.F., and Maloney, T.J., 1999, New reporting procedures based on long-term method detection levels and some considerations for interpretations of water-quality data provided by the U.S. Geological Survey National Water Quality Laboratory: U.S. Geological Survey Open-File Report 99-193, 19 p.

Paerl, H.W., 1988, Nuisance phytoplankton blooms in coastal, estuarine, and inland waters: Limnology and Oceanography, v. 33, no. 4_part_2, p. 823-847.

Paerl, H.W., and Fulton, R.S., III, 2006, Ecology of harmful cyanobacteria, chap. 8 of Graneli, E., and Turner, J.T., eds., Ecology of harmful algae: Berlin, Springer, p. 95-107.

Paerl, H.W., and Otten, G.T., 2013, Harmful cyanobacterial blooms - Causes, consequences, and controls: Environmental Microbiology, v. 65, p. 995-1010.

$\mathrm{R}$ Core Team, 2020, $\mathrm{R}-\mathrm{A}$ language and environment for statistical computing, ver. 3.6.1: Vienna, Austria, R Foundation for Statistical Computing, accessed January 5, 2019, at https://www.R-project.org/.

Runkel, R.L., Crawford, C.G., and Cohn, T.A., 2004, Load Estimator (LOADEST) - A FORTRAN program for estimating constituent loads in streams and rivers: U.S. Geological Survey Techniques and Methods, book 4, chapter A5, 69 p., accessed June 2, 2018, at https://pubs .usgs.gov/tm/2005/tm4A5/.

Shaughnessy, A.R., Sloan, J.J., Corcoran, M.J., and Hasenmueller, E.A., 2019, Sediments in agricultural reservoirs act as sinks and sources for nutrients over various timescales: Water Resources Research, v. 55, no. 7, p. 5985-6000.

Smith, H.G., Sheridan, G.J., Lane, P.N.J., Nyman, P., and Haydon, S., 2011, Wildfire effects on water quality in forest catchments - A review with implications for water supply: Journal of Hydrology (Amsterdam), v. 396, no. 1-2, p. 170-192.

Smith, V.H., 1983, Low nitrogen to phosphorus ratios favor dominance by blue-green algae in lake phytoplankton: Science, v. 221, no. 4611, p. 669-671, accessed June 2020 at https://science.sciencemag.org/content/221/4611/ 669.abstract.

Smith, V.H., and Schindler, D.W., 2009, Eutrophication science-Where do we go from here?: Trends in Ecology \& Evolution, v. 24, no. 4, p. 201-207.

Solberg, P.A., 2020, Phytoplankton data for Stagecoach Reservoir near Steamboat Springs, Colorado, July 2017 through September 2018: U.S. Geological Survey data release, accessed May 20, 2020, at https://doi.org/10.5066/ P9EZBCAO. 
Terziotti, S., Hoos, A.B., Harned, D.A., and Garcia, A.M., 2010, Mapping watershed potential to contribute phosphorus from geologic materials to receiving streams, southeastern United States: U.S. Geological Survey Scientific Investigations Map 3102, 1 sheet.

Thomas, J.C., McMahon, P.B., and Arnold, L.R., 2019, Groundwater quality and hydrology with emphasis on selenium mobilization and transport in the lower Gunnison River Basin, Colorado, 2012-16: U.S. Geological Survey Scientific Investigations Report 2019-5029, 69 p., accessed April 20, 2020, at https://doi.org/10.3133/sir20195029.

Tobin, R.L., 1996, Initial effects of Stagecoach Reservoir on discharge, water-quality characteristics, and suspendedsediment loads in the Yampa River, northwestern Colorado: U.S. Geological Survey Water-Resources Investigations Report 95-4101, 111 p.

Topper, R., Spray, K.L., Bellis, W.H., Hamilton, J.L., and Barkmann, P.E., 2006, Ground water atlas of Colorado: Denver, Colo., Colorado Geological Survey Online Publication ON-06-01, accessed July 9, 2019, at https://coloradogeologicalsurvey.org/water/coloradogroundwater-atlas/.

Turnipseed, D.P., and Sauer, V.B., 2010, Discharge measurements at gaging stations: U.S. Geological Survey Techniques and Methods book 3, chap. A8, 87 p., accessed March 4, 2020, at https://doi.org/10.3133/tm3A8.

Tweto, O., 1979, MI-16 geologic map of Colorado: Denver, Colo., Colorado Geological Survey, Department of Natural Resources, 1 plate, scale 1:500,000, accessed August, 5, 2018, at https://coloradogeologicalsurvey.org/publications/ tweto-geologic-map-colorado-1979/.

Udall, B., and Overpeck, J., 2017, The twenty-first century Colorado River hot drought and implications for the future: Water Resources Research, v. 53, no. 3, p. 2404-2418.

U.S. Census Bureau, 2020, Quick facts-Routt County, Colorado; United States: U.S. Census Bureau website, accessed February 2020 at https://www.c ensus.gov/quickfacts/fact/table/routtcountycolorado,US/ PST040218\#PST04021.

U.S. Environmental Protection Agency, 2016, Fact sheetDraft human health recreational ambient water quality criteria/swimming advisories for microcystins and cylindrospermopsin: U.S. EPA, Office of Water, EPA 822-D1_6001, 2 p., accessed June 1, 2020, at https://archiv e.epa.gov/epa/sites/production/files/2016-12/documents/ draft-hh-rec-ambient-water-swimming-factsheet.pdf.
U.S. Geological Survey, [USGS], 2010, Office of Water Quality Technical Memorandum 2010.07-Changes to the reporting convention and to data qualification approaches for selected analyte results reported by the National Water Quality Laboratory (NWQL): U.S. Geological Survey, Office of Water Quality. [Also available at https://water .usgs.gov/admin/memo/QW/qw10.07.html.]

U.S. Geological Survey [USGS], 2020, USGS water data for the Nation: U.S. Geological Survey National Water Information System database, accessed March 20, 2020, at https://doi.org/10.5066/F7P55KJN.

U.S. Geological Survey, [USGS], [variously dated], National field manual for the collection of water-quality data: U.S. Geological Survey Techniques of Water-Resources Investigations, book 9, chaps. A1-A9, accessed June 15, 2018, at https://pubs.usgs.gov/twri/index090905.html.

Van Meter, K.J., Chowdhury, S., Byrnes, D.K., and Basu, N.B., 2020, Biogeochemical asynchrony-Ecosystem drivers of seasonal concentration regimes across the Great Lakes Basin: Limnology and Oceanography, v. 65, no. 4, p. $848-862$.

Wetzel, R.G., 1983, Limnology, 2d. ed.: Philadelphia, Pa., Saunders College Publishing, 767 p., accessed June 19, 2019, at https://openlibrary.org/books/OL3787950M/ Limnology.

Woodhouse, C.A., Pederson, G.T., Morino, K., McAfee, S.A., and McCabe, G.J., 2016, Increasing influence of air temperature on upper Colorado River streamflow: Geophysical Research Letters, v. 43, no. 5, p. 2174-2181, accessed April 4, 2020, at https://doi.org/10.1002/2015GL067613.

World Health Organization, 2003, Guidelines for safe recreational water environments - Volume 1 - Coastal and fresh waters: Geneva, Switzerland, World Health Organization, $253 \mathrm{p}$.

Publishing support provided by the Science Publishing Network, Denver Publishing Service Center

For more information concerning the research in this report, contact the Director, USGS Colorado Water Science Center

Box 25046, Mail Stop 415

Denver, CO 80225

(303) 236-4882

Or visit the Colorado Water Science Center website at

https://www.usgs.gov/centers/co-water 
